BNL- 65560

Informal Report

\title{
RADIATION DOSE AND RISK TO RECREATIONAL FISHERMEN FROM INGESTION OF FISH CAUGHT NEAR EIGHT OIL PLATFORMS IN THE GULF OF MEXICO
}

Anne F. Meinhold and Seymour Holtzman

June 1998

Prepared for:

National Petroleum Technology Office

United States Department of Energy

Tulsa, Oklahoma

Energy Science and Technology Division Department of Applied Science

Brookhaven National Laboratory

Upton, New York 

BNL- 65560

Informal Report

\title{
RADIATION DOSE AND RISK TO RECREATIONAL FISHERMEN FROM INGESTION OF FISH CAUGHT NEAR EIGHT OIL PLATFORMS IN THE GULF OF MEXICO
}

\author{
Anne F. Meinhold and Seymour Holtzman \\ Energy Science and Technology Divișion \\ Department of Applied Science \\ Brookhaven National Laboratory \\ Upton, New York
}

June 1998

Prepared for United States Department of Energy

Assistant Secretary for Fossil Energy

Mr. David Alleman, Project Manager

National Petroleum Technology Office

Tulsa, OK

Work Performed Under Contract No. DE-ACO2-98CH10886

With the U.S. Department of Energy 


\section{DISCLAIMER}

This report was prepared as an account of work sponsored by an agency of the United States Government. Neither the United States Government nor any agency thereof, nor any of their employees, nor any of their contractors, subcontractors, or their employees, makes any warranty, express or implied, or assumes any legal liability or responsibility for the accuracy, completeness, or usefulness of any information, apparatus, product, or process disclosed, or represents that its use would not infringe privately owned rights. Reference herein to any specific commercial product, process or service by trade name, trademark, manufacturer, or otherwise, does not necessarily constitute or imply its endorsement, recommendation, or favoring by the United States Government or any agency, contractor, or subcontractor thereof. The views and opinions of authors expressed herein do not necessarily state or reflect those of the United States Government or any agency, contractor or subcontractor thereof. 


\section{ACKNOWLEDGMENTS}

The United States Department of Energy, Office of Fossil Energy supported this work, with guidance from Mr. David Allemarl as project officer. The primary contractor for the DOE sponsored field study mentioned in the text was Continental Shelf Associates, Inc. (CSA) in Jupiter, Florida. We thank Dr. David Gettleson and Dr. Alan Hart of CSA and Dr. John Trefry of the Florida Institute of Technology for their support. Steimle \& Associates, Inc. performed the survey of recreational fishermen. We thank Dr. Fred Shultz, Dr. Stephen Steimle, Dr. Maureen Mulino and Mr. Michael Rayle of Steimle \& Associates, and Dr. John Francis at the University of New Orleans for their support in the analysis of the survey results. Dr. Stanislav Uryasev of Brookhaven National Laboratory performed the statistical analysis of the radionuclide concentrations measured in finfish. We also thank Dr. Sam Morris and Dr. Michael Rowe of Brookhaven National Laboratory for help with the analysis of the recreational fishermen survey as well as many other useful comments and suggestions. 



\section{CONTENTS}

\section{Page}

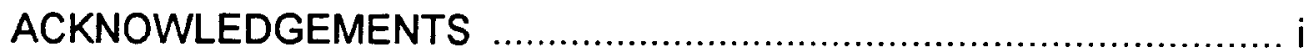

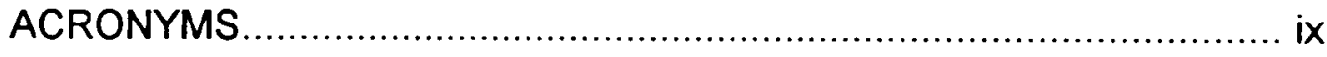

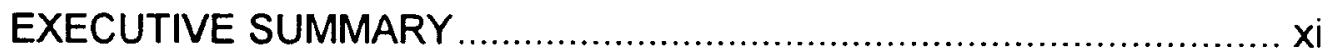

1 INTRODUCTION

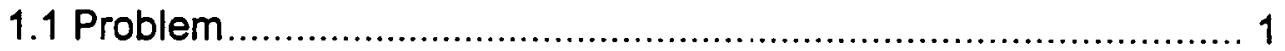

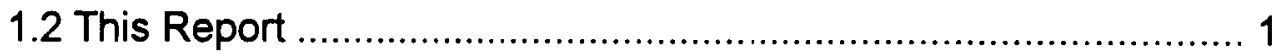

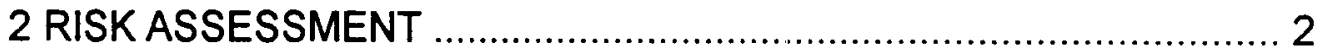

2.1 Risk Assessment and Risk Management .................................. 2

2.2 Human Health Risk Assessment................................................ 2

2.3 Dose Limits and Acceptable Risk ............................................ 3

2.4 Dose and Risk in Perspective ............................................... 4

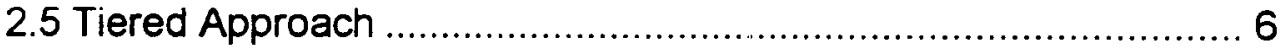

3 HAZARD AND RECEPTOR IDENTIFICATION …......................... 7

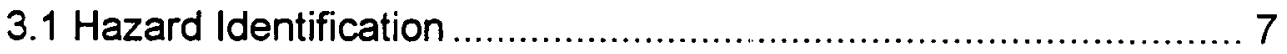

3.2 Exposure Pathways and Receptors ...................................... 7

4 FISH INGESTION RATES AND TARGET SPECIES FOR

RECREATIONAL FISHERMEN …............................................. 9

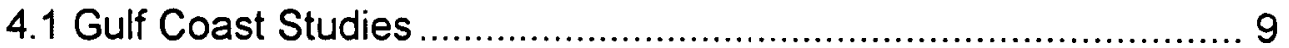

4.2 Published Consumption Rates................................................ 13

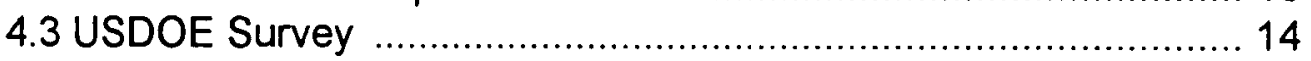

5 OFFSHORE STUDY SITES AND RADIONUCLIDES IN SURFACE

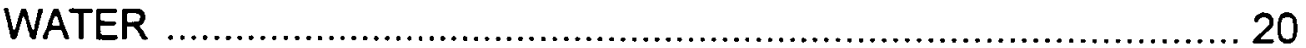

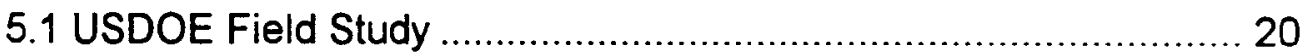

5.2 Offshore Sampling Locations ..................................................... 20

5.3 Sampling and Analytical Methods ............................................ 23

5.4 Concentrations of Radionuclides in Water................................. 24

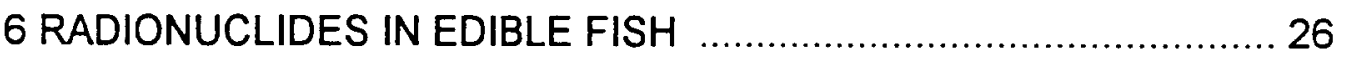

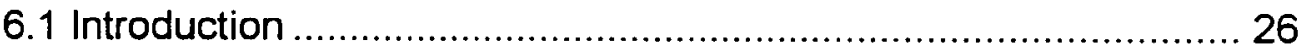

6.2 Fish Species Used in the Analysis........................................ 26

6.3 Comparisons Among Sampling Locations and Fish Species........ 29 
Page

7 DOSE-RESPONSE AND DOSE CONVERSION FACTORS.............. 36

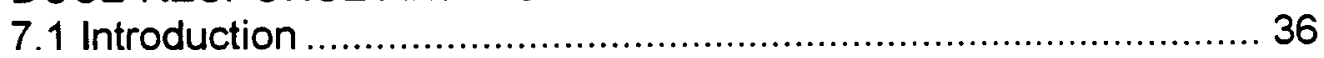

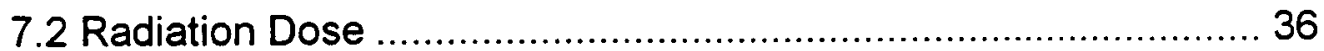

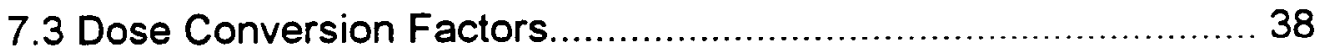

7.4 Radiation Effects and Risk Factors .......................................... 38

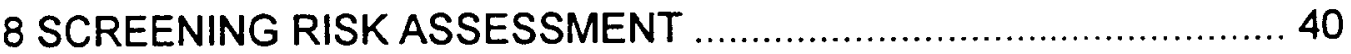

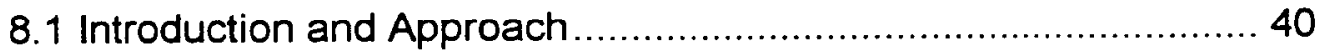

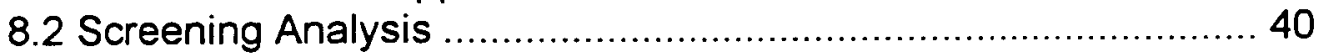

8.3 Screening Results .............................................................. 42

9 QUANTITATIVE RISK ASSESSMENT ........................................ 43

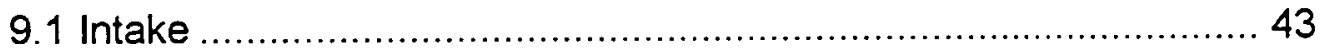

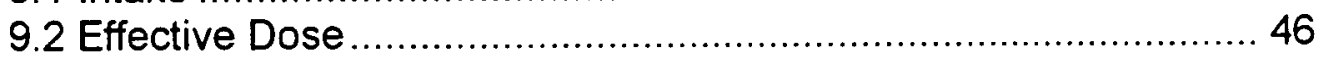

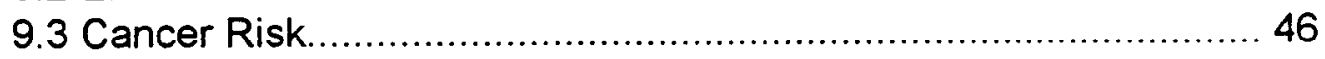

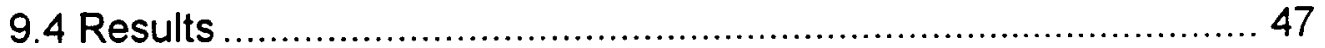

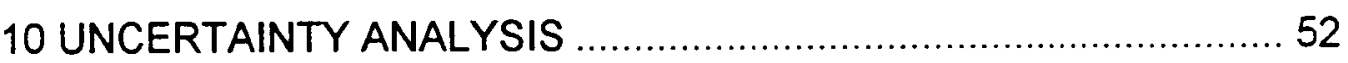

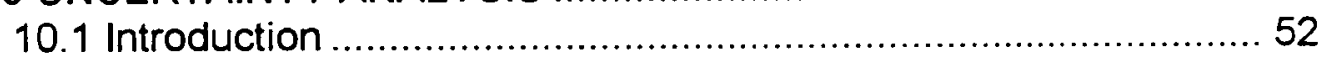

10.2 Uncertainties in Exposure Estimates ..................................... 52

10.3 Uncertainties in Identifying Produced Water Impacts ................ 56

10.4 Uncertainties in Dose-response ............................................... 57

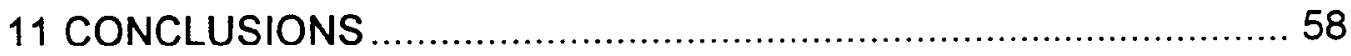

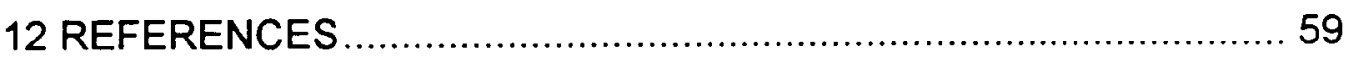

APPENDIX A Recreational Fishermen Survey Instrument................... 63

APPENDIX B Concentrations of ${ }^{210} \mathrm{~Pb},{ }^{226} \mathrm{Ra}$ and ${ }^{228} \mathrm{Ra}$ in Fish .......... 68 
Figures

Page

4-2. Ingestion rate distribution for adult recreational fishermen in the Gulf of Mexico

5-1. Offshore study sites

6-1. Average concentration of ${ }^{210} \mathrm{~Pb},{ }^{226} \mathrm{Ra}$ and ${ }^{228} \mathrm{Ra}$ in fish species used in the quantitative risk analysis at two reference stations and eight discharging platforms.

6-2. Average concentration of ${ }^{210} \mathrm{~Pb},{ }^{226} \mathrm{Ra}$ and ${ }^{228} \mathrm{Ra}$ in different fish species used in the quantitative risk analysis

6-3. Average concentration of ${ }^{210} \mathrm{~Pb}$ and ${ }^{2.26} \mathrm{Ra}$ in two groups of fishes (porgy and all other species) used in the quantitative risk analysis.

9-1. Mean, minimum and maximum annual estimated doses ( $\mathrm{mSv} / \mathrm{y})$ to adult recreational fishermen from ingestion of ${ }^{210} \mathrm{~Pb},{ }^{226} \mathrm{Ra}$ and ${ }^{228} \mathrm{Ra}$ in fish caught near eight discharging platforms and two reference sites in the Gulf of Mexico.

9-2. Mean, minimum and maximum lifetime estimated doses (mSv) to adult recreational fishermen from ingestion of ${ }^{210} \mathrm{~Pb},{ }^{226} \mathrm{Ra}$ and ${ }^{228} \mathrm{Ra}$ in fish caught near eight discharging platforms and two reference sites in the Gulf of Mexico. 49

9-3. Mean, minimum and maximum lifetime estimated cancer incidence risk to adult recreational fishermen from ingestion of ${ }^{210} \mathrm{~Pb},{ }^{226} \mathrm{Ra}$ and ${ }^{228} \mathrm{Ra}$ in fish caught near eight discharging platforms and two reference sites in the Gulf of Mexico.. 50

10-1. Example of major contributors to the variance of the overall risk assessment $\left({ }^{210} \mathrm{~Pb}\right.$ in fish at $\left.\mathrm{H} 1382\right)$..... 


\section{Tables}

page

2-1. ICRP and NCRP recommendations for exposures to the public.... 4

2-2. Selected average exposures and dose limits ........................... 5

4-1. Preferences of anglers in Louisiana who target specific species of saltwater fish and shellfish ................................................. 10

4-2. Age distribution of Louisiana anglers........................................ 11

4-3. Number of years spent fishing by saltwater anglers .................... 12

4-4. Frequency and percent of the number of seafood meals consumed by respondents who ate fish during the week prior to interview.

4-5. Recommendations for ingestion rates of self-caught marine finfish by marine recreational fishermen (USEPA, 1997).

4-6. Percent of Louisiana respondents reporting catch of target species

4-7. Percent of Texas respondents reporting catch of target species... 17

4-8. Number of times per week recreationally caught fish served 18

4-9. Distribution of quantity of fish consumed per eating occasion ( $g$ ) by age and sex....

4-10. Summary statistics, ingestion rate distribution for adult recreational fishermen in the Gulf of Mexico

5-1. Study site descriptions (modified from Hart et al., 1996) ............. 22

5-2. Finfish species sampled and analyzed for radionuclides ............. 24

5-3. Mean concentrations of radionuclides in produced water, the plume, and ambient water at the eight discharging sites.... 
6-1. Finfish species sampled at discharging and reference sites

6-2. Fish species sampled and analyzed for radionuclides, shaded species and portions were used in the quantitative risk assessment

6-3. Concentrations of radionuclides in fish species used in the quantitative risk assessment.

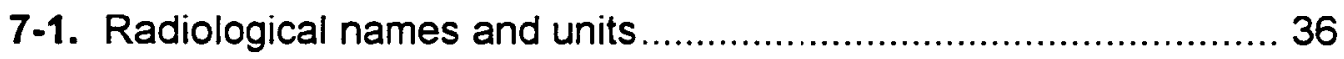

7-2. Prefixes used in radiation protection......................................... 36

7-3. Age-dependent dose conversion factors (equivalent dose to age 70 years, Sv/Bq; ICRP67)

7-4. ICRP (1991) probability coefficients for stochastic effects 39

7-5. USEPA slope factors. 39

8-1. Maximum radionuclide concentrations ( $\mathrm{pCi} / \mathrm{g}$ wet weight) and screening cancer incidence risk for radionuclides in any fish species and parts of fishes at eight discharging platforms and two reference locations

9-1. Normal distributions of radionuclide concentrations in fish used in the quantitative risk assessment

9-2. Correlation coefficients between radionuclide concentrations in fishes.

9-3. Parameters used to calculate intake distributions.

9-4. Lifetime Intake (pCi) distributions. 46

9-5. Estimated annual and lifetime effective dose distributions (mSv) for adult recreational fishermen from ingestion of ${ }^{210} \mathrm{~Pb},{ }^{226} \mathrm{Ra}$ and ${ }^{228} \mathrm{Ra}$ in fish 
9-6. Individual lifetime cancer incidence risk for adult recreational fishermen from ingestion of ${ }^{210} \mathrm{~Pb},{ }^{226} \mathrm{Ra}$ and ${ }^{228} \mathrm{Ra}$ in fish.

9-7. Percent probability that total lifetime cancer risk incidence from ingestion of ${ }^{210} \mathrm{P}_{-5} \mathrm{~b},{ }^{226} \mathrm{Ra}$ and ${ }^{228} \mathrm{Ra}$ in fish ( $\geq$ specified risk values $\left(1 \times 10^{-6}, 1 \times 10^{-5}, 1 \times 10^{-4}\right)$

10-1. Sensitivity analysis, for species used in calculation of risk; mean fishermen individual lifetime cancer incidence risk to adult recreational from ingestion of ${ }^{210} \mathrm{~Pb},{ }^{226} \mathrm{Ra}$ and ${ }^{228} \mathrm{Ra}$ in self-caught fish.

10-2. Sensitivity analysis example (HI382) for exposure duration, ........56 


\section{ACRONYMS}

$\begin{array}{ll}\text { ALARA } & \text { As Low as Reasonably Achievable } \\ \text { ANOVA } & \text { Analysis of Variance } \\ \text { BNL } & \text { Brookhaven National Laboratory } \\ \text { CSA } & \text { Continental Shelf Associates, Inc. } \\ \text { ED } & \text { Exposure Duration } \\ \text { EI } & \text { Eugene Island } \\ \text { HEAST } & \text { Health Effects Assessment Summary Tables } \\ \text { HI } & \text { High Island } \\ \text { ICRP } & \text { International Commission on Riadiological Protection } \\ \text { IR } & \text { Individual Lifetime Cancer Risk } \\ \text { IRIS } & \text { Integrated Risk Information System } \\ \text { LDEQ } & \text { Louisiana Department of Environmental Quality } \\ \text { MDL } & \text { Method Detection Limit } \\ \text { MI } & \text { Matagorda Island } \\ \text { NCRP } & \text { National Council on Radiation Protection and Measurements } \\ \text { ND } & \text { Not Detected } \\ \text { NESHAPS } & \text { National Emission Standards for Hazardous Air Pollutants } \\ \text { NMFS } & \text { National Marine Fisheries Service } \\ \text { NORM } & \text { Naturally Occurring Radioactive Material } \\ \text { NRC } & \text { National Research Council; Nuclear Regulatory Commission } \\ \text { PAH } & \text { Polycyclic Aromatic Hydrocarbon } \\ \text { RBE } & \text { Relative Biological Effectiveness } \\ \text { SAS } & \text { Statistical Analysis System } \\ \text { SB } & \text { Sonnier Bank } \\ \text { SD } & \text { Standard Deviation } \\ & \end{array}$




$\begin{array}{ll}\text { SEM } & \text { Standard Error of the Mean } \\ \text { SI } & \text { Systeme International } \\ \text { SMI } & \text { South Marsh Island } \\ \text { SF } & \text { Slope Factor } \\ \text { USDA } & \text { United States Department of Agriculture } \\ \text { USDOE } & \text { United States Department of Energy } \\ \text { USEPA } & \text { United States Environmental Protection Agency } \\ \text { VN } & \text { Vermillion }\end{array}$




\section{EXECUTIVE SUMMARY}

\section{Introduction}

Offshore production of oil and gas is accompanied by a saline wastewater, called "produced water". Produced water clischarges to the Gulf of Mexico often contain elevated concentrations of radionuclides that occur naturally in the geologic reservoir along with the oil and gas. These radionuclides may accumulate in organisms that live near offshore oil and gas structures. Because recreational fishing in the Gulf of Mexico is concentrated near oil and gas platforms, there is the potential for increased risks to recreational fishermen from the ingestion of radionuclides in fish caught near produced water discharges.

This analysis investigated the potential risk to recreational fishermen from radium and lead-210 in offshore produced water discharges to the Gulf of Mexico. The assessment used data collected at eight discharging offshore platforms and two reference locations. These data were collected in a USDOE funded project titled "Environmental and Economic Assessment of Discharges from Gulf of Mexico Region Oil and Gas Operations", here called the USDOE Field Study. The risk assessments were done to support risk managers in developing regulations and permits for offshore discharges of produced water.

\section{Risk Assessment}

Risk assessment can be defined as the process of estimating magnitudes and probabilities of potential adverse effects on human health or the environment. Risk assessments provide risk managers with the scientific information needed to balance the degree of risk permitted, against competing risks and the cost of risk reduction. A risk assessment should also frame the results of the analysis in terms of current dose limits, acceptable risk ranges and background exposures.

The International Commission on Radiological Protection (ICRP, 1991) and the National Council on Radiation Protection and Measurements (NCRP,1993) recommend a dose limit for public exposure of $1 \mathrm{mSv} / \mathrm{y}(100 \mathrm{mrem} / \mathrm{y})$. One $\mathrm{mSv} / \mathrm{y}$ received over a 70 year lifetime is associated with a risk for fatal cancer of about $4 \times 10^{-3}$.

The United States Environmental Protection Agency (USEPA) considers excess individual lifetime cancer risks less than $1 \times 10^{-6}$ (one in one million) to $1 \times 10^{-4}$ (one in ten thousand) to be acceptable (Federal Register, 1991). These risk levels are lower than the risks associated with the proposed public dose limits.

In this analysis, a human health risk assessment was done in a tiered approach to estimate the risks posed by radionuclides in offshore produced water 
discharges. A screening analysis using worst case assumptions was done to determine the need for a more detailed analysis. A quantitative, probabilistic risk assessment that considers uncertainties and probabilities of effects was then done.

\section{Hazard Identification}

Many contaminants in produced water have known or suspected human health and or ecological effects at high exposures. This analysis focused on the human health risks of radionuclides discharged in produced water.

Radionuclides known to occur above background surface water concentrations in produced water include ${ }^{226} \mathrm{Ra},{ }^{228} \mathrm{Ra}$, and ${ }^{210} \mathrm{~Pb}$. Other decay products of radium $\left({ }^{210} \mathrm{Po},{ }^{228} \mathrm{Th},{ }^{222} \mathrm{Ra}\right.$ ) may also be expected in produced water. Health effects of radionuclides can be attributed to their radioactive emissions. Alpha, beta and gamma radiation released by the decay of radionuclides cause ionization of cellular components that may result in the mutation or death of affected cells. The health effect of concern is the induction of cancer.

\section{Exposure Pathways and Receptors}

Ingestion of contaminated fish is expected to be the most important exposure route for people, because many of the contaminants found in produced water are known to accumulate in finfish and shellfish. The important receptors are recreational fishermen and their families. Recreational fishermen are important receptors because they may fish close to a platform, return often to the same fishing spot, and ingest a large percentage of the fish they catch. Although mollusks and crustaceans are commercially important in the Gulf of Mexico, most of the seafood caught near platforms by recreational fishermen are finfish.

This analysis focused on adult recreational fishermen. Most recreational fishermen are adult men, who tend to eat more fish than women and children. Adult male recreational fishermen were assumed to catch and eat fish their entire adult lives (age 19-70).

\section{Fish Ingestion Rates for Recreational Fishermen}

The rate of ingestion of self-caught fish by recreational fishermen is a critical parameter in assessing risk from ingestion of radionuclides in fish caught near platforms. To provide data specifically for the Gulf of Mexico, a new survey of fishermen in Louisiana and Texas was done as part of the USDOE Field Study (Steimle \& Associates, 1995).

Recreational and commercial fishermen were surveyed by personal interview from May through November 1993 to determine: categories of seafood taken 
over the previous three months; types of license(s) held; and information on the number, gender and ages of individuals in the household and their seafood consumption habits. Respondents were also interviewed about locations fished, estimated distances from oilfield structures, and species caught.

Most of the interviews reported in the survey were intercept surveys of fishermen at the dock. These data are biased in the sense that the probability of being sampled in an intercept survey is not the same for all members of the target population, and fishermen who fish frequently will be oversampled (Price et al., 1994). To correct for this bias, the individual survey responses were weighted by the inverse of the individual's fishing frequency.

Forty-six percent of respondents reported fishing offshore (3-10 miles) at least some of the time; $33 \%$ fish offshore exclusively. Twenty-nine percent of respondents fish exclusively near structures ( $\leq 1000 \mathrm{ft}), 53 \%$ fish exclusively away from structures (>1000 ft), and $18 \%$ fish in both locations.

Results from the survey were used to derive a distribution for meals/week of selfcaught fish for recreational fishermen. This analysis used the distribution of meal sizes for adult males, age 19-34 derived by Pao et al. (1982) from the USDA Nationwide Food Consumption Survey 1977-78 (USDA, 1983) to represent the meal size distribution for adult recreational fishermen. The ingestion rate $(g / d)$ was calculated using the distributions described above for meals/week and meal size, in a Monte Carlo analysis (Figure E-1).

Figure E-1. Ingestion rate distributions for adult recreational fishermen in the Gulf of Mexico.

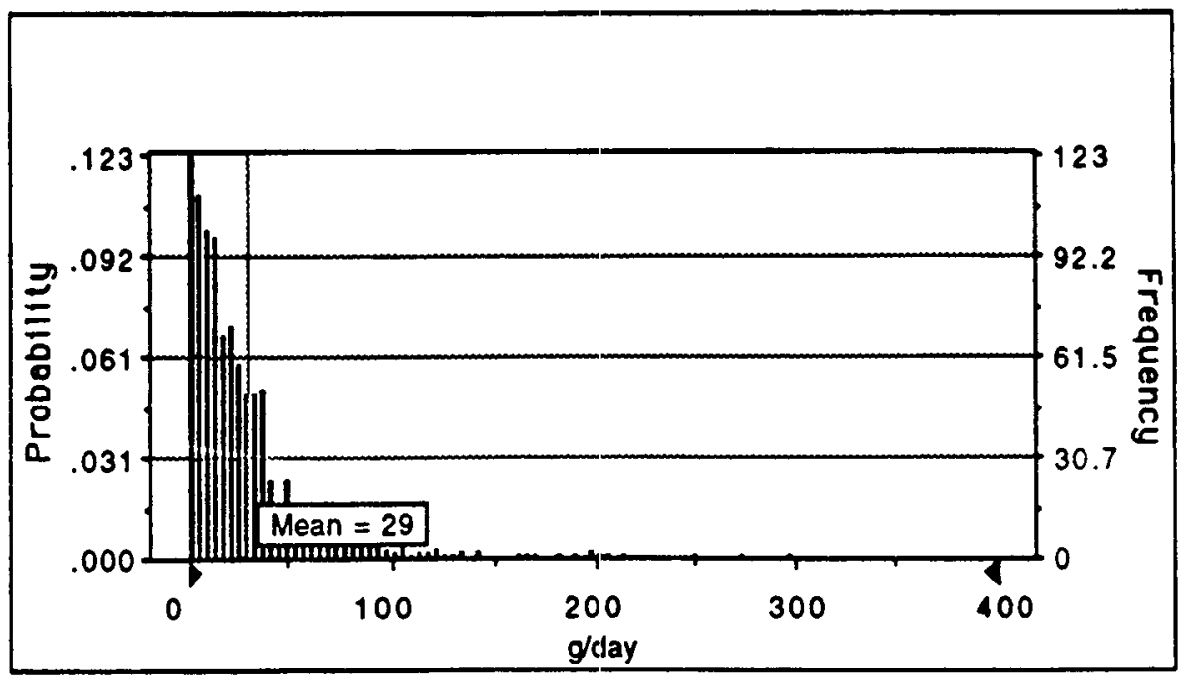




\section{Offshore Study Sites}

The risk assessment used data collected in the USDOE field study of offshore study sites in Louisiana and Texas. Samples were collected at eight discharging and 6 reference sites in the Gulf of Mexico. Concentrations of metals, PAHs, and naturally occurring radioactive materials (NORM) were measured in the discharges, ambient water, sediments and organisms (CSA, 1997).

Radionuclides were measured only in organisms captured near two reference sites, and near the eight discharging sites. The reference stations included a platform structure where produced water has never been discharged (SMI-229), and a natural reef (Sonnier Bank). Although measurements were made on molluscs and crustaceans, this assessment used only concentrations of radionuclides measured in finfish because recreational fishermen routinely seek and eat piscivorous species only.

Radionuclides discharged at these platforms disperse quickly, and are within or close to ambient levels 5 meters from the discharge. Background concentrations in fish are variable and close to detection limits at some locations and at easily measurable levels at others.

\section{Fish Species Used in the Analysis}

Fish species caught and analyzed for radionuclide content in the DOE field study included species that are desirable target species, (e.g. red snapper); species that may sometimes be eaten by fishermen (e.g. porgy) and those that are rarely or never eaten (e.g. cutlassfish). Most species were partitioned into edible and non-edible portions for analysis while smaller specimens were analyzed whole (i.e. porgy, grunt).

The fish species caught vary among sampling locations because the platforms are at different depths and experience different oceanographic conditions. Species with different life histories and degree of association with the platform structure are also represented. Table E-1 lists the species sampled and the portions analyzed.

Only fish species and portions of fish assumed to be eaten by recreational fishermen were included in the quantitative risk assessment (Table E-1). The analysis assumed that the mix of fish caught during the DOE survey represented the mix of fish recreational fishermen would eat at each platform. Porgy and croaker were assumed to be eaten whole, because some fishermen do eat these species whole or use them in soup, but including these whole fish in the analysis is probably conservative because radionuclide concentrations are higher in the bone and skin. 
Table E-1. Fish species sampled and analyzed for radionuclides; shaded species and portions were used in the quantitative risk assessment.

\begin{tabular}{|c|c|c|c|}
\hline Finfish Species & Portion & Ecology & Eaten \\
\hline Aithonfo o roaker & Whole & not structure associated & YES, whole and fillets \\
\hline Atlantic Cutlassfish & whole & not structure alssociated & NO \\
\hline Bach orom $/$. & $\begin{array}{l}\text { nitel } \\
\text { carcass }\end{array}$ & not structure associated & YES, fillets \\
\hline Glaunders & Milet & not structure associated & YES, fillets \\
\hline Gray Hggengh & $\begin{array}{l}\text { fillot }=\text {. } \\
\text { carcass }\end{array}$ & $\begin{array}{l}\text { common and tropically } \\
\text { dependent on structure }\end{array}$ & YES, fillets \\
\hline Greater wink ongos. & $\begin{array}{l}\text { Eifer } \\
\text { carcass }\end{array}$ & may be structure associated & YES, fillets \\
\hline Great Barracuda & fillet & $\begin{array}{l}\text { tropically dependent on } \\
\text { structure }\end{array}$ & NO \\
\hline OHans & Allors & not structure associated & YES, fillets \\
\hline Hardhead Catfish & whole & may be structure associated & NO \\
\hline Gane Snappe' & $\begin{array}{l}\text { Oiflet } \\
\text { carcass }\end{array}$ & $\begin{array}{l}\text { tropically dependent on } \\
\text { structure }\end{array}$ & YES, fillets \\
\hline Yongsping Porgy. & $10016=$ & $\begin{array}{l}\text { not common or tropically } \\
\text { dependent on structure }\end{array}$ & $\begin{array}{l}\text { YES, whole and fillets } \\
\text { Not a target species }\end{array}$ \\
\hline Longtail Bass & IIlle? & $\begin{array}{l}\text { associated with structure, } \\
\text { tropically dependent }\end{array}$ & YES, fillets \\
\hline Pinfish & fillet & not associatea with structure & NO \\
\hline Reo snapper? & $\begin{array}{l}\text { GiIlet } \\
\text { carcass }\end{array}$ & $\begin{array}{l}\text { common and tropically } \\
\text { dependent on structure }\end{array}$ & YES, fillets \\
\hline Redish (ned orum) & MIIet & not structure associated & YES, fillets \\
\hline Sereass & $\begin{array}{l}\text { mulet } \\
\text { carcass }\end{array}$ & common near structures & YES, whole and fillet \\
\hline Sperafl Trout? & $\begin{array}{l}\text { Gilet } \\
\text { carcass }\end{array}$ & incidental & YES, fillets \\
\hline Trouts. & whole & incidental & YES, whole and fillet \\
\hline Wernitilions shapper. & $\begin{array}{l}\text { fillet } \\
\text { carcass }\end{array}$ & $\begin{array}{l}\text { common and tropically } \\
\text { dependent on structure }\end{array}$ & YES, fillets \\
\hline Wencirian & Whole: & $\begin{array}{l}\text { common and tropically } \\
\text { dependent on structure }\end{array}$ & $\begin{array}{l}\text { YES, whole and fillets } \\
\text { Not a target species }\end{array}$ \\
\hline
\end{tabular}

\section{Radionuclides in Fishes: Comparisons Between Locations and Species}

The radionuclides of concern in this analysis $\left({ }^{210} \mathrm{~Pb},{ }^{226} \mathrm{Ra}\right.$, and ${ }^{228} \mathrm{Ra}$ ) occur naturally in fish in the Gulf of Mexico, and concentrations will vary with location, fish species, fish size, and other unknown factors. This analysis used One- and Two-way Analysis of Variance and the Duncan's Multiple Range Test (SAS statistical package) to try to identify differences in radionuclide concentrations in fish among platforms, and among species. 
Significant differences were found between platforms for ${ }^{210} \mathrm{~Pb}$ and ${ }^{226} \mathrm{Ra}$ in fish, but these differences were not consistently between the two reference locations (Sonnier Bank and SMI229) and the discharging platforms.

Porgy had the highest and most variable concentrations of ${ }^{210} \mathrm{~Pb}$, and for porgy only, there were significant differences between locations. In general, most of the ${ }^{210} \mathrm{~Pb},{ }^{226} \mathrm{Ra}$ and ${ }^{228} \mathrm{Ra}$ found in fish at the platforms could be attributed mostly or completely to background levels. The exception to this result is for porgy - in this fish species, ${ }^{210} \mathrm{~Pb}$ is probably platform associated at some locations.

These results suggest that use of porgy in the risk analysis will probably result in an overestimate of dose and risk to recreational fishermen, because porgy: had the highest and most variable ${ }^{210} \mathrm{~Pb}$ concentrations; were analyzed whole; and is not a target species for fishermen in the Gulf of Mexico.

\section{Dose-Response and Dose Conversion Factors}

Current practice in radiation protection assumes there is a cancer risk associated with even small doses of radiation. To describe cancer risks associated with small exposures, human epidemiological data for high dose exposures are extrapolated down to low doses. This approach probably overestimates risks at low doses.

There are two methods available to estimate the risk associated with exposure to radionuclides ingested in food. The first estimates cancer incidence per $\mathrm{pCi}$ of lifetime intake using USEPA's slope factor. The other method uses dose conversion factors to calculate the effective dose ( $\mathrm{Sv}$ or mrem) per intake. This dose can be converted to a lifetime cancer risk estimate using risk factors developed by ICRP (1991).

\section{Screening Risk Assessment}

A screening assessment was done for ${ }^{210} \mathrm{~Pb},{ }^{226} \mathrm{Ra}$ and ${ }^{228} \mathrm{Ra}$ in fish caught near the offshore study sites. This analysis followed the USEPA approach to estimating risks from carcinogens, by applying slope factors to conservative estimates of intake rates (USEPA, 1989). The screening assessment was done to determine the need for a more realistic probabilistic analysis.

Exposure assumptions used in the screening analyses were conservative (90 and 95th percentile upper bound values), as described in USEPA (1989). Concentrations in fish were the maximum measured in any species, in any part of the fish. These intake estimates are extremely conservative and were used here in a screening assessment to determine if an additional, more realistic and labor intensive effort is needed, not to estimate human health risks. 
Incremental lifetime cancer incidence risk (IR) was calculated by multiplying the estimated intake $(\mathrm{pCi})$ by the slope factor (risk per $\mathrm{pCi}$ ). Screening IR values greater than $1 \times 10^{-6}$ suggest a need for further quantitative assessment of carcinogenic risk. All screening risks for the eight discharging platforms were greater than $1 \times 10^{-4}\left(2.2 \times 10^{-4}\right.$ to $\left.1.3 \times 10^{-3}\right)$ and suggested the need for further analysis. The screening risk estimates for the two reference locations were also greater than $1 \times 10^{-4}\left(1.2 \times 10^{-4}, 6.4 \times 10^{-4}\right)$.

\section{Quantitative Risk Assessment}

A more realistic and quantitative assessment was done to estimate distributions of effective dose and cancer incidence risk, for adult recreational fishermen who eat fish caught near produced water discharging platforms in the Gulf of Mexico. The analysis used measured concentrations of ${ }^{210} \mathrm{~Pb},{ }^{226} \mathrm{Ra}$ and ${ }^{228} \mathrm{Ra}$ in edible flesh and in whole fish for species likely to be eaten by fishermen.

Over an extended period, a fisherman is expected to catch and eat a range of fishes with contaminant concentrations that would approach a central tendency. Therefore, normal distributions of concentrations were assumed, and in each distribution the standard error of the mean was substituted for the standard deviation of the data (Seiler and Alvarez, 1996) in the Monte Carlo calculations.

Exposure duration was assumed to be the adult life of recreational fishermen, from age 19 to age 70 (52 years). This is a conservative assumption, and in reality exposure duration may range from several years to a lifetime. Annual doses were also calculated.

The analysis used the distributions $(\mathrm{g} / \mathrm{d}$ ) derived using the data collected in the survey of recreational fishermen for intake of self-caught fish. The analyses conservatively assumed that $100 \%(F=1)$ of a recreational fisherman's intakes are from fishing near a discharge. Intake distributions of contaminants were calculated using the USEPA method (USEPA, 1989) in a Monte Carlo analysis.

Dose conversion factors used were those for adults given in the Recommendations of the ICRP (1991). Effective doses for ${ }^{210} \mathrm{~Pb},{ }^{226} \mathrm{Ra}$ and ${ }^{228} \mathrm{Ra}$ were summed for each platform. Cancer incidence risk was estimated from the estimated effective dose distributions (Sv) and the ICRP (1991) risk factor for the public.

Estimated annual dose and lifetime cancer risk distributions for ${ }^{210} \mathrm{~Pb},{ }^{226} \mathrm{Ra}$ and ${ }^{228} \mathrm{Ra}$ are shown in Figures E-2 and E-3. Doses and risks for the eight discharging platforms are similar to those for the two reference sites. Estimated annual doses are all well below the ICRP(1991) and NCRP (1993) suggested 1 $\mathrm{mSv} / \mathrm{y}$ for the public. 
Figure E-2. Mean, minimum and maximum annual estimated doses (mSv/y) to recreational fishermen from ingestion of ${ }^{210} \mathrm{~Pb},{ }^{226} \mathrm{Ra}$ and ${ }^{228} \mathrm{Ra}$ in fish caught near eight discharging platforms and two reference sites in the Gulf of Mexico.

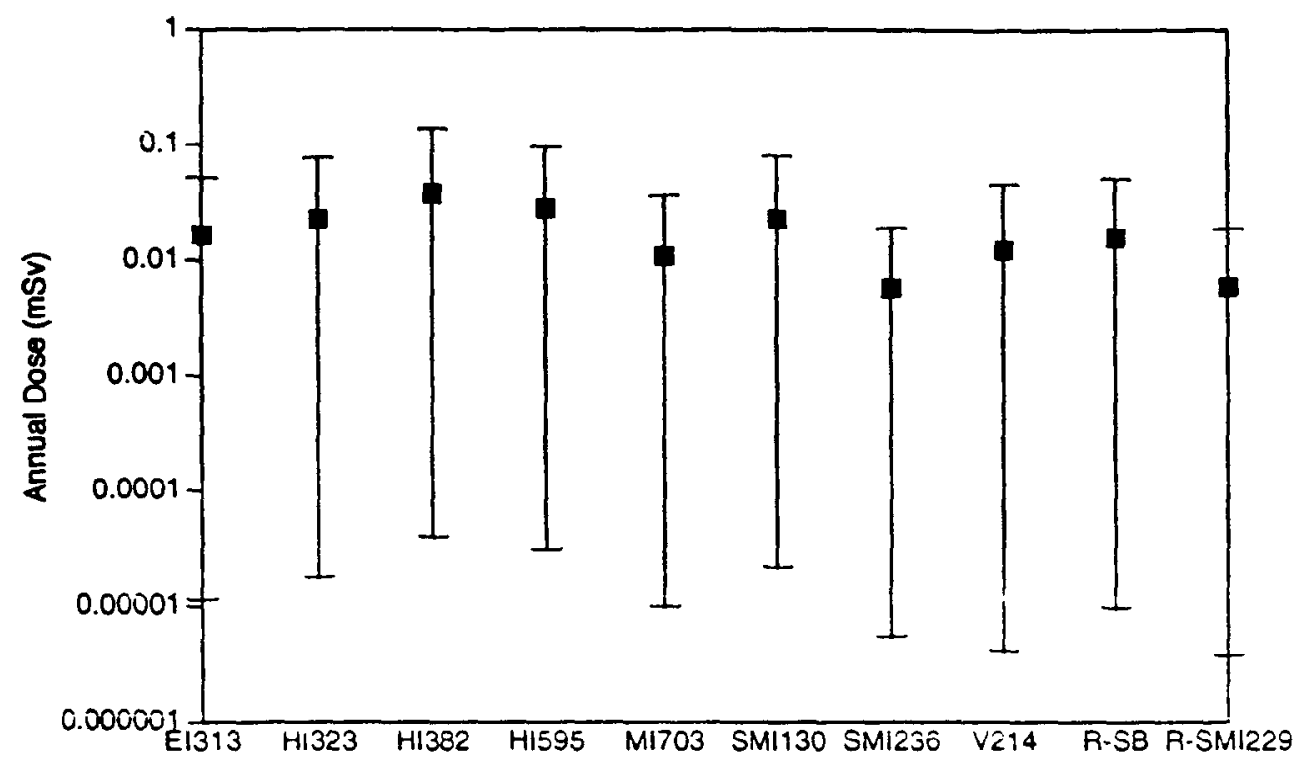

Figure E-3. Mean, minimum and maximum estimated lifetime cancer incidence risk to recreational fishermen from ingestion of ${ }^{210} \mathrm{~Pb},{ }^{226} \mathrm{Ra}$ and ${ }^{228} \mathrm{Ra}$ in fish caught near eight discharging platforms and two reference sites in the Gulf of Mexico.

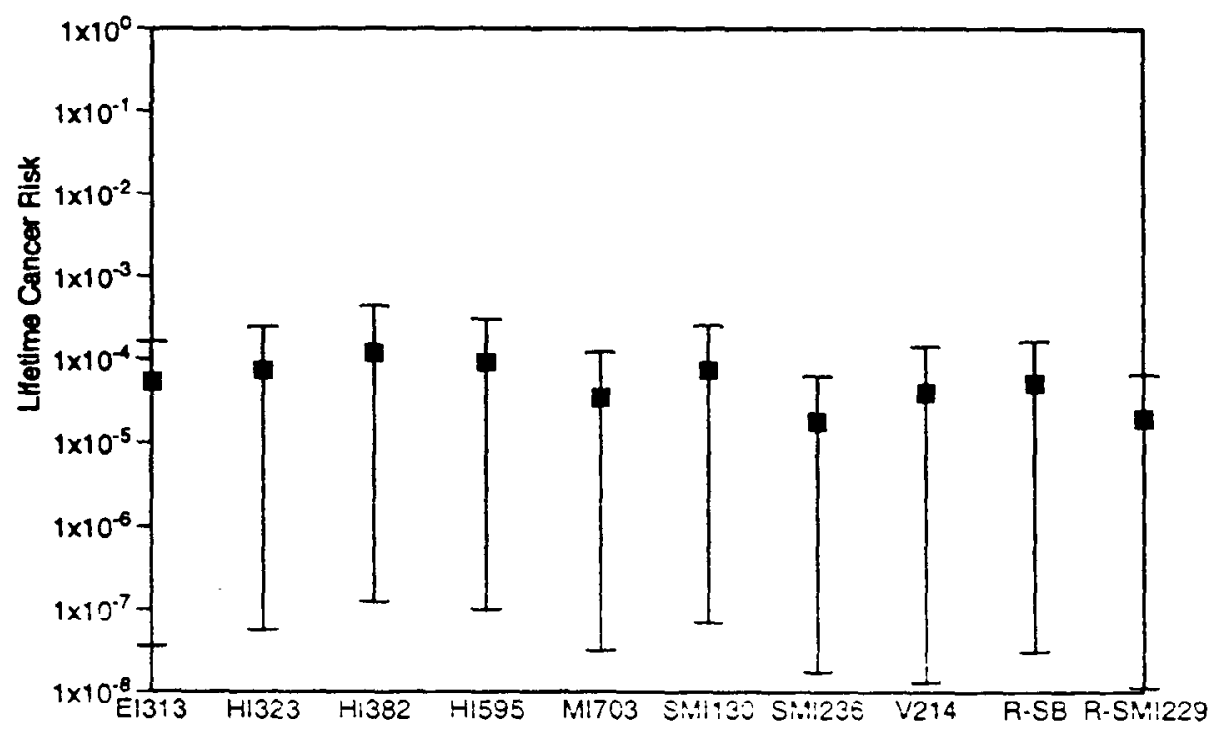


Mean individual lifetime cancer incidence risks for all platforms except $\mathrm{HI} 382$ are less than the $1 \times 10^{-4}$ level commonly considered acceptable by USEPA. The risks associated with ingestion of fish caught at the two reference sites are within the range for seven of the eight discharging sites (H1382 is larger). This suggests that some or all of the radionuclides in fish at the produced water discharging platforms is associated with background. The mean risk for $\mathrm{HI} 382$ just exceeds the $1 \times 10^{-4}$ level. The estimated annual dose at $\mathrm{HI} 382$ is $4 \%$ of the ICRP recommended dose limit for the public.

\section{Uncertainty Analysis}

Uncertainties associated with the assumptions used in this analysis include the intakes of contaminants by recreational fishermen, exposure duration, and the dose-response relationships used to calculate risks.

Uncertainties in annual intake were included in the assessment by describing concentrations in fish and fish intake rates as distributions in the Monte Carlo analysis. Because of a lack of knowledge or data, a number of assumptions were not treated probabilistically. These assumptions are those for which deterministic, single value assumptions were made, including exposure duration and radionuclide dose conversion and risk factors.

\section{Uncertainties in Concentrations in Fish and Fish Species Eaten by Fishermen}

The concentrations of radionuclides in fishes caught near the platforms are uncertain. A small number of samples (12-30) were used to establish the distributions of radionuclide concentrations in fish at each location. Measured concentrations were often close to or less than MDLs, as well as being close to average background levels. Small sample sizes and incorrect weighting of the species in terms of which are most likely to actually be eaten, could lead to major under-or overestimates of radionuclide concentrations in fish.

The species caught at each platform include species likely to be trophically associated with the platform structure (grey triggerfish), species that are resident near platforms but not completely trophically dependent on them (red snapper, vermillion snapper) and species that are probably not residents (croaker, trout). It was assumed that the fish that were sampled are representative of what recreational fishermen catch at each location.

Since the trophically dependent fish species and other fish with high concentrations of radionuclides are generally not the preferred target fish species for recreational fishermen, intake and risk was probably overestimated. Another conservative assumption embedded in the analysis was the assumption that recreational fishermen ate whole porgy and croakers caught near the platforms. Porgy was the dominant species in terms of radionuclide 
concentrations, but these fish are not preferred target species in the Gulf of Mexico.

Risks associated with ingestion of radionuclides in porgy were always higher, by approximately an order of magnitude. The assumption that fishermen eat whole porgy probably results in an overestimate of risk because porgy has high concentrations of NORM and is not a target species.

\section{Quantity of Self Caught Fish Ingested by Recreational Fishermen}

The estimate of meal size yielded a contribution to the variance of the overall risk estimates that was approximately twice that of all other distributions combined. These data were based on an analysis of the 1977-1978 survey (Pao et al., 1982) and are probably representative of the US population, and of the range of fish meal sizes eaten by adult men.

Most of the remaining variance (approximately $40 \%$ of total) comes from the distribution of meals/week derived from data collected in the survey of recreational fishermen done as part of the USDOE field study. Since these data are based on a survey of fishermen in the Gulf of Mexico, and because the results were very similar for all groups considered (i.e. Texas and Louisiana; offshore and coastal fishermen), most of the variance in the estimate is probably due to the true variability in the number of self-caught fish meals eaten by recreational fishermen.

\section{Duration of Exposure}

Because of the lack of available data on exposure period, adult recreational fishermen were assumed to eat self-caught fish for their entire adult lives (age 19-70; 52 years). This assumption is a conservative one, but is within reasonable bounds - fishermen have reported fishing for $1-5$ to $66-70$ years. Most fishermen probably fish and eat their catch for a shorter period of time. There is a linear relationship between increased risk with increasing duration of recreational fishing activity; up to an order of magnitude of difference between 5 and 52 years of fishing.

\section{Uncertainties in Identifying Produced Water Impacts}

Identifying the impacts of produced water discharges on fishes living close to the platforms, and therefore on recreational fishermen eating those fish was difficult because there are background concentrations of radionuclides in the water, sediments and fishes of the Gulf of Mexico that have nothing to do with a particular discharge. These background concentrations are variable and vary in space and time. 
Significant differences were found between platforms for ${ }^{210} \mathrm{~Pb}$ and ${ }^{226} \mathrm{Ra}$ concentrations in fish, but these differences were not consistently between the two reference locations (Sonnier Bank and SMI229) and the discharging platforms.

Porgy had the highest and most variable concentrations of ${ }^{210} \mathrm{~Pb}$, and for porgy only, there were significant differences between locations. In general, most of the ${ }^{210} \mathrm{~Pb},{ }^{226} \mathrm{Ra}$ and ${ }^{228} \mathrm{Ra}$ found in fish at the platforms could be attributed mostly or completely to background levels. The exception to this result is for porgy - in this fish species, ${ }^{210} \mathrm{~Pb}$ is likely platform associated at some locations.

The cancer risks of interest are incremental risks - that is the risks associated with the discharges alone. Because the risk assessment included all ${ }^{210} \mathrm{~Pb}$ and radium measured in fish caught near these platforms, the results over-estimate the contribution from the platforms. In some cases, all of the estimated risks could be from background concentrations of these naturally occurring radionuclides.

\section{Uncertainties in Dose Response}

There is uncertainty associated with both the dose conversion factors and the risk factors used to relate intake to dose and cancer risk. Uncertainties in dose conversion factors result from the natural variation in human beings in the way radioactive materials move through the body, and in uncertainties in the individual's age at exposure and length of exposure. This assessment used standard, deterministic values for dose conversion factors developed for the average population. These dose conversion factors commit the dose from bone seekers like radium and lead beyond the length of a human life, and so probably slightly overestimate dose. They are well documented and widely used.

The risk factors used are also standard, internationally accepted values (ICRP, 1991). NCRP (1997) concluded that the values of lifetime risk per Sv can range from about one-fourth to about twice the nominal value, with a mean that is lower than the nominal value.

One way to deal with these uncertainties in dose and risk is to use the same values to estimate risks associated with background concentrations of radionuclides in fishes, which are similar to those for fish caught near discharging platforms. 


\section{Conclusions}

Fish caught near most platforms had concentrations of radionuclides that were very similar to concentrations in fish caught at two reference sites in the Gulf of Mexico. The platform with the highest predicted dose and risk had a mean annual dose that was $4 \%$ of the recommended pubic exposure from all sources. This platform had a predicted mean lifetime cancer incidence risk of $1.2 \times 10^{-4}$. Most or all of this risk could be associated with background concentrations of radionuclides, and ingestion of fish species that are not commonly caught or eaten by recreational fishermen.

Assumptions used in this risk assessment may contribute to an overestimate of risk. These include inclusion of whole porgy in the analysis and the assumption of lifetime exposure.

Concentrations of radium measured in fish caught near platforms are probably not platform associated. Lead-210, particularly in porgy (or other whole fish) may be partially associated with the produced water discharges at some locations.

Recreational fishermen and their families are expected to face a negligible risk of carcinogenic effects from ingesting radionuclides in fishes caught near the sampled produced water discharges.

\section{References}

CSA, 1997, Radionuclides, Metals and Hydrocarbons in Oil and Gas Operational Discharges And Environmental Samples Associated with Offshore Production Facilities on the Texas/Louisiana Continental Shelf with an Environmental Assessment of Metals and Hydrocarbons, prepared by Continental Shelf Associates, Inc., Jupiter Florida, for the United States Department of Energy.

Federal Register, 1991, National Primary Drinking Water Regulations; Radionuclides, United States Environmental Protection Agency, 40 CFR Parts 141,142, 56:138:33050.

ICRP, 1991, "1990 Recommendations of the International Commission on Radiological Protection", Publication 60, Annals of the ICRP, 21:1-3, Pergamon Press, Oxford. 
ICRP, 1994, "Age Dependent Doses to Members of the Public From Ingestion of Radionuclides", Recommendations of the International Commission on Radiological Protection", Publication 67, Annals of the ICRP, 23 Pergamon Press, Oxford.

NCRP, 1997, Uncertainties in Fatal Cancer Risk Estimates Used in Radiation Protection, National Council on Radiation Protection and Measurements, Bethesda, MD., NCRP Report No. 126.

NCRP, 1993, Limitation of Exposure to lonizing Radiation, National Council on Radiation Protection and Measurements, Bethesda, MD., NCRP Report No. 116.

Pao, E.M., K.H. Fleming. P.M. Guenther and S.J. Mickle, 1982, Foods Commonly Eaten by Individuals: Amount Per Day and Per Eating Occasion, United States Department of Agriculture, Home Economics Report No. 44.

Price, P.S., Su, S.H., and M.N. Gray, 1994, "The Effect of Sampling Bias on Estimates of Angler Consumption Rates in Creel Surveys", J. Exposure Analysis and Environmental Epidemiology, 4:3 355-372.

Seiler, F., and Alvarez, J.L., 1996, "On the Selection of Distributions for Stochastic Variables", Risk Analysis 16: 5-18.

Steimle \& Associates, Inc., 1995, Synthesis of Seafood Catch, Distribution, And Consumption Patterns in the Gulf of Mexico Region, report prepared for the United States Department of Energy, New Orleans, LA.

USDA, 1983, Food Intakes: Individuals in 48 States, Year 1977-1978, United States Department of Agriculture, Hyattsville, MD., Nationwide Food Consumption Survey 1977-78, Report No. 1-1.

USEPA, 1997, Exposure Factors Handbook, Office of Health and Environmental Assessment, United States Environmental Protection Agency, Washington, D.C., EPA $600 / P-95 / 002 F a$

USEPA, 1989, Risk Assessment Guidance for Superfund, Volume I, Human Health Evaluation Manual (Part A) Interim Final, Office of Emergency and Remedial Response, EPA 540/1-89/002, United States Environmental Protection Agency, Washington, D.C. 


\section{INTRODUCTION}

\subsection{Problem}

Offshore production of oil and gas is accompanied by a saline wastewater, called "produced water". Produced water clischarges to the Gulf of Mexico often contain elevated concentrations of radionuclides that occur naturally in the geologic reservoir along with the oil and gas. These radionuclides may accumulate in organisms that live near offshore oil and gas structures. Because recreational fishing in the Gulf of Mexico is concentrated near oil and gas platforms, there is the potential for increased risks to recreational fishermen from the ingestion of radionuclides in fish caught near produced water discharges.

\subsection{This Report}

This report is part of a series of studies of the health and ecological risks from discharges of produced water to the Gulf of Mexico, supported by the United States Department of Energy (USDOE). These assessments provide input to regulators in the development of guidelines and permits, and to industry in the development of appropriate discharge practices.

This analysis investigated the potential risk to recreational fishermen from radium and lead-210 in offshore produced water discharges. The assessment used data collected at eight discharging offshore platforms and two reference locations in the Gulf of Mexico. These data were collected in a USDOE funded project titled "Environmental and Economic Assessment of Discharges from Gulf of Mexico Region Oil and Gas Operations", here called the USDOE Field Study. The risk assessments were done to support: risk managers in developing regulations and permits for offshore discharges of produced water.

Section 2 gives an overview of human health risk assessment and helps put the analyses and results in perspective. Section 3 presents the hazard identification step of the risk assessment, and identifies the important exposure pathways and receptors for radionuclides discharged in produced water. Section 4 derives fish ingestion rates for recreational fishermen. Section 5 describes the sampled stations and methods used in the USDOE Field Study, and a more detailed analysis of the data for concentrations of radionuclides in edible fish is given in

Section 6. Section 7 describes the dose conversion and risk factors for ${ }^{210} \mathrm{~Pb}$, ${ }^{226} \mathrm{Ra}$ and ${ }^{228} \mathrm{Ra}$. Section 8 presents the screening risk assessment and Section 9 the quantitative probabilistic analysis. An uncertainty analysis is presented in Section 10, and conclusions in Section 11. 


\section{RISK ASSESSMENT}

\subsection{Risk Assessment and Risk Management}

Risk assessment can be defined as the process of estimating magnitudes and probabilities of potential adverse effects on human health or the environment. Risk management involves the political, economic and social decisions and actions taken to accept, mitigate, or control potential risks.

Risk assessments provide risk managers with the scientific information needed to balance the degree of risk permitted against competing risks and the cost of risk reduction. A risk assessment should also frame the results of the analysis in terms of current dose limits, acceptable risk ranges and background exposures.

It is important that the needs and concerns of risk managers be considered in the design of the risk assessment to ensure that the results are relevant, useable, and understandable to risk managers.

\subsection{Human Health Risk Assessment}

The most commonly used framework for human health risk assessment includes the following four phases (NRC, 1983):

- Hazard identification;

- Dose-response assessment;

- Exposure assessment; and

- Risk characterization.

Hazard identification involves the use of exposure and effects data from the laboratory and the field to determine whether the agent of concern can cause health effects, and to identify what those effects are (NRC, 1983).

Dose-response assessment characterizes the relationship between administered dose and the incidence of an adverse effect. Dose-response information is usually derived from animal toxicology studies, clinical studies, or epidemiology studies of people exposed at high levels. Assumptions must be made about the comparability of the response in laboratory animals to that of humans. Statistical methods are usually used to extrapolate the dose-response function from high experimental doses to the generally much lower doses in the human population.

Exposure assessment estimates the magnitude, frequency and duration of exposure, and characterizes subgroups of the human populations subject to different levels of exposure. This phase includes estimating the source term, fate and transport of the contaminant(s) of concern, and subsequent human exposure. 
Risk characterization integrates the results of the previous phases, estimates the incidence of an adverse human health effect, and describes the uncertainties in the data and assumptions. Human health risks are described as the probability of an adverse health effect (e.g., cancer death or toxic effect) in an individual of an exposed population (individual risk), or the number of health effects expected in the population (population risk) for a given time interval.

\subsection{Dose Limits and Acceptable Risk}

Publications of the International Commission on Radiation Protection (ICRP) are cited as the basis for most dose limits promulgated in the United States. ICRP (1991) presents a framework for radiological protection as well as specific recommendations for the control of both public and occupational exposures.

The ICRP system for controlling exposure of the general public to radiation from practices (as opposed to remediation) is based on the following assumptions: the practice causing exposure should be adopted only if sufficient benefit is produced to offset any detriment; exposure should be kept as low as reasonably achievable, economic and social factors being taken into account; and exposures should be subject to dose limits.

ICRP (1991) recommends a dose limit for public exposure of $1 \mathrm{mSv} / \mathrm{y}$ (100 $\mathrm{mrem} / \mathrm{y})$. This value was chosen based on an assessment of the risks associated with radiation exposure and the variation in exposure from natural background (average is approximately $1 \mathrm{mSv} / \mathrm{y}$, excluding radon). One $\mathrm{mSv} / \mathrm{y}$ received over a 70 year lifetime is associated with a risk for fatal cancer of about $4 \times 10^{-3}$.

The National Council on Radiation Protection and Measurements (NCRP,1993) also recommends a dose limit to the general public for exposures to man-made sources other than medical and natural background of $1 \mathrm{mSv} / \mathrm{y}(100 \mathrm{mrem} / \mathrm{yr})$ (Table 2-1). NCRP also recommends that no single source or set of sources under one control should result in an individual being exposed to more than 0.25 $\mathrm{mSv} / \mathrm{y}$ (25 mrem/yr). Following these recommendations, USEPA is proposing radiation protection guidance for federal agencies that would require a dose limit of $100 \mathrm{mrem} / \mathrm{yr}(1 \mathrm{mSv} / \mathrm{y})$. 
Table 2-1. ICRP and NCRP recommendations for exposures to the public.

\begin{tabular}{|c|l|}
\hline & \multicolumn{1}{|c|}{ Recommendation } \\
ICRP (1991) & $1 \mathrm{mSv} / \mathrm{y}(100 \mathrm{mrem} / \mathrm{y}) ;$ ALARA assumed \\
NCRP (1993) & $1 \mathrm{mSv} / \mathrm{y}(100 \mathrm{mrem} / \mathrm{y}) ; 5 \mathrm{mSv} / \mathrm{y}$ for infrequent exposures \\
NCRP (1993) & $0.25 \mathrm{mSv} / \mathrm{y}(25 \mathrm{mrem} / \mathrm{y})$ from a single source \\
\hline
\end{tabular}

ALARA (As Low as Reasonably Achievable) is part of the system of radiation protection suggested by ICRP and NCRP and adopted by USDOE (USDOE, 1991), the United States Environmental Protection Agency (USEPA) and the Nuclear Regulatory Commission (NRC). ALARA is a process for reducing exposures to radiation taking into account the societal, environmental, technological, economic and practical and public policy considerations to make a judgment concerning the optimum level of public health protection. ALARA refers to reducing exposures to reasonably achievable levels after a dose limit has been met.

The United States Environmental Protection Agency (USEPA) considers excess individual lifetime cancer risks less than $1 \times 10^{-6}$ (one in one million) to $1 \times 10^{-4}$ (one in ten thousand) to be acceptable (Federal Register, 1991). USEPA recently proposed standards for radionuclides in drinking water the agency considers to be associated with an individual lifetime cancer risk of approximately $1 \times 10^{-4}$ (Federal Register, 1991). This risk range is also used to determine if action is required at a Superfund site, and to derive cleanup goals when standards are not available (National Contingency Plan, Federal Register 8686, March 8, 1990). These risk levels are lower than the risks associated with the proposed public dose limits. This comparison is presented in the following section.

\subsection{Dose and Risk in Perspective}

The dose from natural background excluding radon is made up of exposures from cosmic radiation $(27 \mathrm{mrem} / \mathrm{y})$, terrestrial radiation $(28 \mathrm{mrem} / \mathrm{y})$, radionuclides in the body $(40 \mathrm{mrem} / \mathrm{y})$, the nuclear fuel cycle $(0.4 \mathrm{mrem} / \mathrm{y})$ and fallout (1.1 mrem/y) (average values for the United States; NCRP, 1993). The primary determinant of outdoor adsorbed dose in air from terrestrial radiation is the soil concentration of naturally occurring radionuclides. Naturally occurring potassium-40 is the biggest contributor to the dose from terrestrial radiation.

Background exposures fluctuate due to seasonal cycles and variation in cosmic radiation. The variation in exposure to cosmic radiation is about $10 \%$ over the 
11 year solar cycle. Doses from exposure to background radiation also vary spatially, and the dose from cosmic radiation is a function of latitude and altitude.

Assessing the importance of potential exposures to naturally occurring radioactive materials (NORM) discharged in produced water should be done with reference to dose limits suggested by NCRP and ICRP and variations in background exposures. Table 2-2 shows average background doses in the United States and selected dose limits.

Table 2-2. Selected average exposures and dose limits.

\begin{tabular}{|c|c|c|}
\hline Dose & $\begin{array}{c}\text { Source of Exposure } \\
\text { or } \\
\text { Dose Limit }\end{array}$ & $\begin{array}{c}\text { Cancer } \\
\text { Incidence Risk }\end{array}$ \\
\hline $3 \mathrm{mSv} / \mathrm{y}(300 \mathrm{mrem} / \mathrm{y})$ & EXPOSURE: average total background in US & $1.3 \times 10^{-2}$ \\
\hline $2 \mathrm{mSv} / \mathrm{y}(200 \mathrm{mrem} / \mathrm{y})$ & EXPOSURE: average from radon & $8.4 \times 10^{-3}$ \\
\hline $1 \mathrm{mSv} / \mathrm{y}(100 \mathrm{mrem} / \mathrm{y})$ & $\begin{array}{c}\text { EXPOSURE: average background } \\
\text { (excluding radon) }\end{array}$ & $4.2 \times 10^{-3}$ \\
\hline & $\begin{array}{l}\text { DOSE LIMIT: ICRP /NCRP recommendations, } \\
\text { all sources (excluding } \\
\text { background and medical) }\end{array}$ & $1.8 \times 10$ \\
\hline & $\begin{array}{l}\text { DOSE LIMIT: USEPA proposed all sources } \\
\text { (excluding background and medical) }\end{array}$ & $1.8 \times 10^{-3}$ \\
\hline & DOSE LIMIT: NRC licensed operations & $1.8 \times 10$ \\
\hline $0.25 \mathrm{mSv} / \mathrm{y}(25 \mathrm{mrem} / \mathrm{y})$ & $\begin{array}{c}\text { DOSE LIMIT: NCRP recommendation, } \\
\text { single source }\end{array}$ & $4.5 \times 10^{-4}$ \\
\hline $0.10 \mathrm{mSv} / \mathrm{y}(10 \mathrm{mrem} / \mathrm{y})$ & $\begin{array}{c}\text { DOSE LIMIT: USEPA NESHAPS, routine } \\
\text { air emissions }\end{array}$ & $1.8 \times 10^{-4}$ \\
\hline $0.04 \mathrm{mSv} / \mathrm{y}(4 \mathrm{mrem} / \mathrm{y})$ & DOSE LIMIT: USEPA drinking water standards & $7.2 \times 10^{-2}$ \\
\hline
\end{tabular}

risk factor: $6 \times 10^{-2}$ incidence/Sv, 70-year exposure for background exposures, 30 years for dose limits 


\subsection{Tiered Approach}

A tiered approach to risk assessment is logical and cost-effective. In a tiered approach, the initial analysis is a conservative (i.e. worst-case) screening step, designed to eliminate from further analyses contaminants and pathways that are not of concern in terms of potential impacts to human health or ecological values. Further analyses are unnecessary when conservative models and assumptions yield estimated risks that are small (i.e. individual lifetime cancer incidence risk less than $1 \times 10^{-6}$ ). If a conservative analysis suggests that risks may be high, a more detailed, comprehensive, and realistic assessment is done.

A commonly used tool in probabilistic, quantitative risk assessment is Monte Carlo analysis. In a Monte Carlo analysis, a sample from the distribution of an input parameter is placed into a simulation to interact in a model with samples from other input parameters.

In this analysis, the steps in a human health risk assessment outlined by NRC (1983) were applied in a tiered approach to estimate the human health risks posed by radionuclides in offshore produced water discharges. A screening analysis using worst case assumptions was used to determine the need for a more detailed, quantitative analysis. A quantitative, probabilistic risk assessment that considers uncertainties and probabilities of effects was then done.

Both the screening analysis and the probabilistic analysis required data describing the population of concern, the amount of fish eaten by this population, and the potential concentrations of radionuclides in fish caught near the platforms. These data were developed from results of the USDOE Field Study (CSA, 1997; Hart et al., 1996; Trefry et al., 1996). 


\section{HAZARD AND RECEPTOR IDENTIFICATION}

\subsection{Hazard Identification}

Hazard identification uses exposure and effects data from the laboratory and field, to determine whether the agent of concern can cause health effects, and to identify those effects (NRC, 1983).

Many contaminants in produced water have known or suspected human health and or ecological effects at high exposures. This analysis focuses on the human health risks of radionuclides discharged in produced water. Risks associated with the discharge of metals and PAHs at these sites are addressed in a separate report.

Radionuclides known to occur above background surface water concentrations in produced water include ${ }^{226} \mathrm{Ra},{ }^{228} \mathrm{Ra}$, and ${ }^{210} \mathrm{~Pb}$. Other decay products of radium $\left({ }^{210} \mathrm{Po},{ }^{228} \mathrm{Th},{ }^{222} \mathrm{Ra}\right.$ ) may also be expected in produced water.

Health effects of radionuclides can be attributed to their radioactive emissions. Alpha, beta and gamma radiation released by the decay of radionuclides cause ionization of cellular components that may result in the mutation or death of affected cells.

Current practice in radiation protection assumes that there is a cancer risk associated with even very small doses of radiation. For cancer risk from small exposures, risk factors are derived from epidemiological data and extrapolated down to low doses. This practice may overestimate the risks from small doses of radiation.

\subsection{Exposure Pathways and Receptors}

Sportfishing off the coast of Louisiana is concentrated around oil and gas platforms (Witzig, 1986; Reggio, 1987). A survey by Ditton and Auyong (1984) in the Gulf of Mexico found heavy use of offshore platforms by private recreational fishing boats.

Stanley and Wilson (1990) surveyed recreational fishermen in Louisiana. Fiftyfive private vessel owners and 10 charter boat operators from fishing clubs in Louisiana maintained logbooks from March 1987 through December 1988. In this study (Stanley and Wilson, 1990), the most common fishing method for both private and charter boat operators was offshore bottom fishing. Participants most often fished at large multiwell production platforms, although all platform sizes were used. 
Ingestion of contaminated fish is expected to be the most important exposure route for people, because many of the contaminants found in produced water are known to accumulate in finfish and shellfish. The important receptors for contaminants discharged in produced water are recreational fishermen and their families. Recreational fishermen are important receptors because they may fish close to a platform, return often to the same fishing spot, and ingest a large percentage of the fish they catch. Although mollusks and crustaceans are commercially important in the Gulf of Mexico, most of the seafood caught near platforms by recreational fishermen are finfish.

Commercial fishermen may fish near platform structures, but usually at a greater distance than recreational fishermen. Commercially caught fishes are marketed widely, making the prediction of an individual's consumption from a single source difficult (USEPA, 1990). Because the catch of sports fishermen is not diluted in this way, they represent the population most vulnerable to exposure by consumption of contaminated fishes from one location (USEPA, 1990). Some sports fishermen may sell or give away the fish they catch, but an analysis of their consumption and risk will result in a more conservative estimate of risk than an assessment of risk for the general public. Recreational fishermen may also include commercial fishermen who fish near offshore platforms, and eat some of their catch.

This analysis will focus on adult recreational fishermen. Most recreational fishermen are adult men, who tend to eat more fish than women and children. Adult male recreational fishermen were assumed to catch and eat fish their entire adult lives (age 19-70). 


\section{FISH INGESTION RATES AND TARGET SPECIES FOR RECREATIONAL FISHERMEN}

The rate of ingestion of self-caught fish by recreational fishermen is a critical parameter in assessing risk from ingestion of radionuclides in fish caught near platforms. There are a few available surveys that can be used to estimate the amount of fish caught and eaten by recreational fishermen. These surveys were done in water bodies other than the Gulf of Mexico and did not address the relationship between offshore structures and recreational fishing. To address this relationship, and to provide data specifically for the Gulf of Mexico, a new survey of fishermen in Louisiana and Texas was done as part of the USDOE Field Study (Steimle \& Associates, 1995; Sichultz et al., 1996).

\subsection{Gulf Coast Studies}

Sportfishing off the coast of Louisiana is concentrated around oil and gas platforms. It has been estimated that over $70 \%$ of all recreational trips beyond three miles from shore occur around platforms (Witzig, 1986; Reggio, 1987).

Stanley and Wilson (1990) performed a survey of recreational fishermen in Louisiana. The most common fishing method for both private and charter boat operators was offshore bottom fishing. Participants most often fished at large multiwell production platforms, although all platform sizes were used. The five most frequently caught species (or groups of species) in 1987 were (descending order): red snapper, spotted seatrout, silver/sand seatrout, other snapper and greater amberjack. In 1988, the five most frequently caught species were (descending order): red snapper, spotted seatrout, other snapper, silver/sand seatrout and grey triggerfish.

Fisheries landing data for 1991 (NMFS, 1992) show that marine recreational anglers in the Gulf of Mexico caught spotted seatrout $15 \%$ of the time. Other frequently caught fish include white grunt, gray snapper, yellowtail snapper, black seabass, Spanish mackerel and sheepshead.

Kelso et al., (1991) used a mail survey to determine the preferences, expenditures and demographics of fresh and saltwater anglers in Louisiana. The survey instrument asked respondents what species they targeted, their age, and how many years they had been fishing (Tables 4-1, 4-2, 4-3). 
Table 4-1. Preferences of anglers in Louisiana who target specific species of saltwater fish and shellfish. Number of times a fish was listed as $1^{\text {st }}, 2^{\text {nd }}$ or $3^{\text {rd }}$ choice; (-) indicates less than $0.05 \%$. From Kelso et al., (1991).

\begin{tabular}{|c|c|c|c|c|c|c|}
\hline \multirow[t]{2}{*}{ Species } & \multicolumn{2}{|c|}{ First Choice } & \multirow{2}{*}{$\begin{array}{l}\text { Second } \\
\text { Choice } \\
\text { No. }\end{array}$} & \multirow{2}{*}{$\begin{array}{l}\text { Third } \\
\text { Choice } \\
\text { No. }\end{array}$} & \multicolumn{2}{|c|}{$\begin{array}{l}\text { No. of times } 1^{\text {st }}, 2^{\text {nd }} \\
\text { or } 3^{\text {ro }} \text { choice }\end{array}$} \\
\hline & No. & $\%$ & & & No. & $\%$ \\
\hline Red Drum & 881 & 42 & 967 & 91 & 1.939 & 35 \\
\hline $\begin{array}{l}\text { Speckled } \\
\text { Seatrout }\end{array}$ & 1,067 & 50 & 751 & 106 & 1,924 & 34 \\
\hline Flounder & 38 & 2 & 129 & 621 & 788 & 14 \\
\hline Black Drum & 6 & - & 41 & 219 & 266 & 5 \\
\hline Red Snapper & 66 & 2 & 33 & 80 & 179 & 3 \\
\hline Sand Seatrout & 3 & - & 12 & 79 & 94 & 2 \\
\hline Atlantic Croaker & 8 & - & 9 & 57 & 74 & $\overline{1}$ \\
\hline Cobia & 6 & - & 20 & 36 & 62 & 1 \\
\hline Sheepshead & 4 & - & 4 & 38 & 46 & 1 \\
\hline King Mackerel & 7 & - & 17 & 22 & 36 & 1 \\
\hline Tuna & 4 & - & 5 & 19 & 28 & 1 \\
\hline Catfish & 6 & - & 5 & 15 & 26 & - \\
\hline Shark & 3 & - & 5 & 15 & 23 & - \\
\hline Grouper & 2 & - & 4 & 10 & 16 & - \\
\hline Blue Crab & 8 & - & 3 & 5 & 16 & - \\
\hline $\begin{array}{l}\text { Spanish } \\
\text { Mackerel }\end{array}$ & 1 & - & 1 & 14 & 16 & - \\
\hline Marlin & 8 & - & 2 & 5 & 15 & - \\
\hline Tarpon & 8 & - & $\overline{1}$ & $\overline{4}$ & 13 & - \\
\hline Amberjack & . & & 6 & 7 & 13 & - \\
\hline Dolphin & 4 & - & 3 & 3 & 10 & - \\
\hline Shrimp & 4 & - & 1 & 3 & 8 & - \\
\hline Striped Bass & 1 & - & 2 & 4 & 7 & - \\
\hline Gar & 3 & - & 1 & 2 & 6 & - \\
\hline Wahoo & . & & 3 & 2 & 5 & - \\
\hline Pompano & 1 & - & 1 & 3 & 5 & - \\
\hline Catfish & 2 & - &. & . & 2 & - \\
\hline Sailfish & 1 & - & 1 & & 2 & - \\
\hline Mullet & . & & 1 & 1 & 2 & - \\
\hline Triggerfish & . & & . & 2 & 2 & - \\
\hline $\begin{array}{l}\text { Largemouth } \\
\text { Bass }\end{array}$ & 1 & - & . & . & 1 & - \\
\hline White Perch & . & & . & 1 & 1 & - \\
\hline Totals & 2,143 & & 2.028 & 1464 & 5635 & \\
\hline
\end{tabular}


Table 4-2. Age distribution of Louisiana anglers; - indicates less than $0.05 \%$; 3,814 anglers reporting. From Kelso et al., (1991).

\begin{tabular}{|c|c|c|c|c|c|}
\hline Age & Number & $\begin{array}{c}\text { Percentage of } \\
\text { Anglers Reporting }\end{array}$ & Age & Number & $\begin{array}{c}\text { Percentage of } \\
\text { Anglers Reporting }\end{array}$ \\
\hline 13 & 3 & $0.1 \%$ & 47 & 85 & $2.2 \%$ \\
\hline 14 &. & & 48 & 86 & $2.3 \%$ \\
\hline 15 & 2 & $0.1 \%$ & 49 & 78 & $2.0 \%$ \\
\hline 16 & 1 & - & 50 & 76 & $2.0 \%$ \\
\hline 17 & 4 & $0.1 \%$ & 51 & 64 & $1.7 \%$ \\
\hline 18 & 18 & $0.5 \%$ & 52 & 74 & $1.9 \%$ \\
\hline 19 & 33 & $0.9 \%$ & 53 & 65 & $1.7 \%$ \\
\hline 20 & 38 & $1.0 \%$ & 54 & 51 & $1.3 \%$ \\
\hline 21 & 47 & $1.2 \%$ & 55 & 64 & $1.7 \%$ \\
\hline 22 & 32 & $0.8 \%$ & 56 & 49 & $1.3 \%$ \\
\hline 23 & 45 & $1.2 \%$ & 57 & 57 & $1.5 \%$ \\
\hline 24 & 72 & $1.9 \%$ & 58 & 55 & $1.4 \%$ \\
\hline 25 & 80 & $2.1 \%$ & 59 & 61 & $1.6 \%$ \\
\hline 26 & 84 & $2.2 \%$ & 60 & 77 & $2.0 \%$ \\
\hline 27 & 97 & $2.5 \%$ & 61 & 42 & $1.1 \%$ \\
\hline 28 & 98 & $2.6 \%$ & 62 & 40 & $1.0 \%$ \\
\hline 29 & 97 & $2.5 \%$ & 63 & 15 & $0.4 \%$ \\
\hline 30 & 137 & $3.6 \%$ & 64 & 6 & $0.2 \%$ \\
\hline 31 & 116 & $3.0 \%$ & 65 & 4 & $0.1 \%$ \\
\hline 32 & 132 & $3.5 \%$ & 66 & 4 & $0.1 \%$ \\
\hline 33 & 145 & $3.8 \%$ & 67 & 5 & $0.1 \%$ \\
\hline 34 & 121 & $3.2 \%$ & 68 & 2 & $0.1 \%$ \\
\hline 35 & 127 & $3.3 \%$ & 69 & 2 & $0.1 \%$ \\
\hline 36 & 114 & $3.0 \%$ & 70 &. &. \\
\hline 37 & 123 & $3.2 \%$ & 71 &. &. \\
\hline 38 & 119 & $3.1 \%$ & 72 &. & . \\
\hline 39 & 111 & $2.9 \%$ & 73 & 1 & - \\
\hline 40 & 143 & $3.7 \%$ & 74 &. & . \\
\hline 41 & 102 & $2.7 \%$ & 75 & 1 & - \\
\hline 42 & 136 & $3.6 \%$ & 76 & 1 & - \\
\hline 43 & 114 & $3.0 \%$ & 77 & 1 & - \\
\hline 44 & 74 & $1.9 \%$ & 78 & 1 & - \\
\hline 45 & 91 & $2.4 \%$ & 79 & 1 & - \\
\hline 46 & 90 & $2.4 \%$ & & & \\
\hline & & & & & \\
\hline
\end{tabular}


Table 4-3. Number of years spent fishing by saltwater anglers; not adjusted by fishermen's age; (-) indicates less than 0.5\%. From Kelso et al., (1991).

\begin{tabular}{|c|c|c|}
\hline Number of years & Number of anglers & $\begin{array}{c}\text { Percentage of those } \\
\text { responding }\end{array}$ \\
\hline & & $15 \%$ \\
\hline $1-5$ & 412 & $18 \%$ \\
\hline $6-10$ & 502 & $14 \%$ \\
\hline $11-15$ & 398 & $16 \%$ \\
\hline $16-20$ & 449 & $11 \%$ \\
\hline $21-25$ & 322 & $11 \%$ \\
\hline $26-30$ & 316 & $6 \%$ \\
\hline $31-35$ & 160 & $6 \%$ \\
\hline $36-40$ & 164 & $2 \%$ \\
\hline $41-45$ & 53 & $2 \%$ \\
\hline $46-50$ & 54 & - \\
\hline $51-55$ & 4 & - \\
\hline $56-60$ & 5 & - \\
\hline $61-65$ & 0 & - \\
\hline $66-70$ & 1 & \\
\hline & & \\
\hline Total responding & 2,840 & \\
\hline
\end{tabular}

There have been two surveys in Louisiana to determine fish and shellfish consumption patterns. Dellenbarger et al. (1993) surveyed residents in south Louisiana over 5 days in the Lenten period in 1993. Seventy percent of the respondents consumed seafood during this period. Crawfish and shrimp were the most commonly consumed shellfish, catfish and bass the most common freshwater fish eaten, and speckled trout the most popular saltwater fish consumed. The authors concluded that for the five-day period of the survey, respondents consumed an average of $16 \mathrm{~g}$ of freshwater finfish, $13 \mathrm{~g}$ of saltwater finfish, and $31 \mathrm{~g}$ of shellfish. The study concluded that income, family size and recreational fishing positively influenced seafood consumption.

Anderson and Rice (1992) surveyed seafood consumption patterns for the greater New Orleans area. A random sample of the general population was interviewed by telephone about their seafood consumption habits for the week prior to the interview. Among the 405 respondents to the survey, $5 \%$ reported never eating seafood, and $34 \%$ reported eating fish or shellfish but not in the last week. Sixty-one percent of the respondents ate seafood during the previous week. Table 4-4 shows the number of times the respondents who ate seafood in the previous week had a fish meal during the week. Shrimp was the most popular seafood with catfish, speckled trout crab and other saltwater fish next in order. The study reported that respondents who ate one serving of seafood the week before the interview consumed between 10.4 and $30.8 \mathrm{~g}$ of fish and between 13.6 and $32.6 \mathrm{~g}$ of shellfish, while respondents who reported consuming two meals per week ate 20.9 to $61.5 \mathrm{~g}$ of fish and 26 to $65.1 \mathrm{~g}$ of shellfish. 
Table 4-4. Frequency and percent of the number of seafood meals consumed by respondents who ate fish during the week prior to interview

(Anderson and Rice, 1992).

\begin{tabular}{|c|c|c|}
\hline $\begin{array}{c}\text { Number of Meals } \\
\text { per Week }\end{array}$ & Number & Percent \\
\hline 1 & 150 & 60.5 \\
2 & 62 & 25.0 \\
3 & 27 & 10.8 \\
4 & 5 & 2.0 \\
$\geq 5$ & 4 & 1.0 \\
\hline
\end{tabular}

\subsection{Published Consumption Rates for Marine Recreational Fishermen}

Available estimates of fish consumption rates vary because of differences in survey methods, water bodies, and the kinds of consumers surveyed (Ebert et al. 1994). A number of surveys of fish consumption in the United States have demonstrated that fish consumption rates differ regionally and within specific subpopulations (NMFS, 1992).

The United States Environmental Protection Agency (USEPA, 1997) suggests values for fish consumption by recreational fishermen based on field interviews performed by the National Marine Fisheries Service (NMFS, 1993) (Table 4-5). The surveys used field interviews with marine anglers on area and mode of fishing, fishing frequency, species caught, weight of fish caught, and whether the fish were intended for consumption. USEPA derived intake rates by assuming that 2.5 consumers would eat each fisherman's catch, and that half of the weight of the catch was edible. The amount of fish caught during the day of the interview was multiplied by the fisherman's self-reported fishing frequency to estimate the total amount of fish caught intended for consumption by each fisherman's family and friends.

These values are recommended by USEPA to represent consumption rates for recreational fishermen in an area with widespread contamination. No specific values are recommended for small water bodies or for areas of localized contamination, because the amount of fish consumed from small areas is likely to be only a percentage of the total amount of self-caught fish eaten by a recreational fishermen. 
Table 4-5. Recommendations for ingestion rates of self-caught marine finfish by marine recreational fishermen (USEPA, 1997).

\begin{tabular}{|l|c|c|}
\hline Study Location & Mean Intake (g/day) & $9^{\text {th }}$ Percentile (g/day) \\
\hline Gulf & 7.2 & 26.0 \\
Atlantic & 5.6 & 18.0 \\
Pacific & 2.0 & 6.8 \\
\hline
\end{tabular}

\subsection{USDOE Survey}

\subsubsection{Need}

Previous risk assessments for radium discharged in produced water found that the variability of fish ingestion rates for recreational fishermen in the Gulf of Mexico contributed a large amount of uncertainty to the final risk estimates (Meinhold et al., 1995).

The USDOE Field Study included a task to describe the catch, consumption, and human use patterns by fishermen and their families of seafood species collected from coastal and offshore waters of the Gulf of Mexico. In the current risk assessment, these survey data were used to derive an intake distribution for ingestion by recreational fishermen of fish caught near oil and gas structures in the Gulf of Mexico.

\subsubsection{Survey Method and Data Filter}

The USDOE survey methods and results are described in Steimle \& Associates, Inc. (1995) and in Shultz et al. (1996). Recreational and commercial fishermen were surveyed by personal interview from May through November 1993 to determine: categories of seafood taken over the previous three months; types of license(s) held; and information on the number, gender and ages of individuals in the household and their seafood consumption habits. Respondents were also interviewed about locations fished, estimated distances from oilfield structures, and species caught. Intercept surveys were done at docking areas located in 9 zones along the Louisiana and Texas Gulf Coast. The recreational fishermen survey instrument is reproduced in Appendix A. 
Fishermen were asked to estimate by species the percentage sold, the percentage given away to others, and the percentage kept for personal consumption. Fishermen were also asked to estimate the frequency of seafood consumption and to name the cooking methods used.

Data collected by the survey (Steimle \& Associates, Inc., 1995) included the following:

- amount of fish caught per trip

- number of trips near and at varying distances from oil and gas structures

- number of trips inshore vs. offshore

- fraction of catch kept

- number of days since last seafood meal

- number of times per week self-caught fish served

- fishing frequency

A total of 894 surveys were completed for Texas and Louisiana. Ninety percent of these were based on the intercept method (fishermen were interviewed at the dock, multiple visits were made to each location, and fishermen were reinterviewed if encountered more than once). Five percent of the surveys were done at Sports Club meetings, and $5 \%$ were re-interviews by telephone of fishermen who had previously been surveyed by the intercept method.

The second two survey methods (Sports Club and telephone surveys) were done to increase the sample size when weather made additional intercept interviews difficult. Re-interviews were done to provide a quality check on the rest of the collected data.

Each of the survey methods used presents its own biases and problems in interpretation. Telephone surveys ordinarily have the advantage that the sampling probability is equal for all members of the target population. In this case, however, telephone surveys were re-interviews of fishermen who had previously been surveyed, introducing an additional bias.

Sports Club interviews allowed a large number of recreational fishermen to be surveyed with minimal effort. These responses may not be typical of the average recreational fishermen in the area, and are likely to be biased toward the more avid fishermen.

Most of the interviews reported in the survey' were intercept surveys of fishermen at the dock. These data are biased in the sense that the probability of being sampled in an intercept survey is not the same for all members of the target population (i.e. marine recreational fishermen in Louisiana and Texas). Fishermen who fish frequently will be oversampled (Price et al., 1994). To 
correct for this bias, the individual survey responses were weighted by the inverse of the individual's fishing frequency.

The following data summaries and intake rates are based only on the intercept survey results, weighted as described above. An additional 77 records were eliminated from this data set because of incomplete responses, and a single record reporting 22 meals/week was rejected as an outlier. A total of 725 responses passed all of the above quality screens and were retained in the analysis.

\subsubsection{Fishing Location and Target Species}

Forty-six percent of respondents reported fishing offshore (3-10 miles) at least some of the time; $33 \%$ fish offshore exclusively. Twenty-nine percent of respondents fish exclusively near structures ( $\leq 1000 \mathrm{ft}$ ), $53 \%$ fish exclusively away from structures (>1000 ft), and $18 \%$ fish in both locations.

Tables 4-6 and 4-7 show the reported species caught by location. There are significant differences in the species caught in Louisiana and in Texas, and near and far from platforms in both states. Of the species reported by $20 \%$ or more of respondents in both states, only Red Snapper is caught more frequently exclusively near platforms.

\subsubsection{Intake Rates}

As described above, individual survey responses for the number of times per week self-caught fish were eaten were weighted by the inverse of the individual's fishing frequency. The resulting distribution for meals/week is given in Table 4-8.

This distribution was based on responses for fishermen who reported fishing inshore, offshore, and both inshore and offshore; close to and away from structures; and in Texas and Louisiana. Estimates based on these groups were not significantly different from the distribution for all fishermen in the data set.

Data that describes the size of a fish meal are needed, in combination with these data on meals per week, to estimate intake rates. Table 4-9 gives the distribution of fish meal sizes by age and sex as derived by Pao et al. (1982) from the USDA Nationwide Food Consumption Survey 1977-78 (USDA, 1983) . The distributions for all three categories of adult males (ages 19-34, 35-65, 6574) are very similar. This analysis used the distribution of meal sizes for adult males, age 19-34 to represent the meal size distribution for adult recreational fishermen. 
Table 4-6. Percent of Louisiana respondents reporting catch of target species. ${ }^{1}$

\begin{tabular}{|lcccc|}
\hline \multicolumn{1}{r}{ Species } & All & $\begin{array}{c}\text { Only Near } \\
\text { Platforms }\end{array}$ & $\begin{array}{c}\text { Only Far } \\
\text { from } \\
\text { Platforms }\end{array}$ & $\begin{array}{c}\text { Near and Far } \\
\text { from } \\
\text { Platforms }\end{array}$ \\
\cline { 2 - 5 } & 80 & 20 & 45 & 15 \\
\hline Redfish & 72 & 19 & 40 & 13 \\
Speckled Trout & 42 & 8 & 27 & 7 \\
Flounder & 25 & 8 & 13 & 13 \\
Black Drum & 22 & 4 & 14 & 4 \\
Sheepshead & 20 & 13 & 2 & 4 \\
Red Snapper & 16 & 6 & 5 & 5 \\
Other & 13 & 4 & 6 & 3 \\
Croaker & 12 & 6 & 3 & 3 \\
Spanish Mackerel & 9 & 5 & 1 & 3 \\
Amberjack & 8 & 5 & 1 & 2 \\
King Mackerel & 7 & 3 & 1 & 4 \\
Shark & 6 & 3 & 1 & 2 \\
Dolphin & 4 & 3 & 0 & 1 \\
Grouper & 4 & 2 & 0 & 2 \\
Tuna & 2 & 1 & 0 & 1 \\
Vermilion Snapper & 1 & 1 & 0 & 0 \\
Kingfish & & & & \\
\hline
\end{tabular}

Corrected for frequency of fishing

Table 4-7. Percent of Texas respondents reporting catch of target species. ${ }^{1}$

\begin{tabular}{|lcccc|}
\hline Species & All & $\begin{array}{c}\text { Only Near } \\
\text { Platforms }\end{array}$ & $\begin{array}{c}\text { Only Far } \\
\text { from } \\
\text { Platforms }\end{array}$ & $\begin{array}{c}\text { Near and Far } \\
\text { from } \\
\text { Platforms }\end{array}$ \\
\cline { 2 - 5 } & 40 & 5 & 30 & 5 \\
Speckled Trout & 38 & 6 & 28 & 4 \\
Redfish & 33 & 19 & 5 & 9 \\
Red Snapper & 24 & 8 & 7 & 9 \\
Dolphin & 24 & 4 & 13 & 7 \\
Other & 23 & 2 & 18 & 3 \\
Flounder & 22 & 11 & 5 & 6 \\
Kingfish & 16 & 4 & 6 & 6 \\
Shark & 15 & 5 & 6 & 4 \\
King Mackerel & 12 & 5 & 4 & 4 \\
Amberjack & 9 & 3 & 5 & 1 \\
Black Drum & 9 & 1 & 6 & 2 \\
Tuna & 7 & 1 & 5 & 1 \\
Croaker & 3 & 1 & 1 & 1 \\
Spanish Mackerel & 3 & 1 & 0 & 1 \\
Vermilion Snapper & 2 & 0 & 2 & 0 \\
Sheepshead & 2 & 1 & 1 & 0 \\
Grouper & 2 & & & \\
\hline
\end{tabular}

Corrected for frequency of fishing. 
Table 4-8. Number of times per week recreationally caught fish served.

\begin{tabular}{|c|c|}
\hline $\begin{array}{c}\text { Number of Meals per } \\
\text { Week }\end{array}$ & Percent \\
\hline 0 & 5.42 \\
\hline 0.25 & 47.30 \\
\hline 0.33 & 0.39 \\
\hline 0.50 & 6.00 \\
\hline 0.60 & 0.19 \\
\hline 0.75 & 0.32 \\
\hline 1.00 & 49.19 \\
\hline 1.50 & 0.10 \\
\hline 2.00 & 21.00 \\
\hline 3.00 & 8.33 \\
\hline 3.50 & 0.01 \\
\hline 4.00 & - \\
\hline 5.00 & 3.96 \\
\hline 6.00 & 0.16 \\
\hline 7.00 & 0.11 \\
\hline 8.00 & 0.04 \\
\hline 9.00 & 0.02 \\
\hline 10.00 & 0.03 \\
\hline 11.00 & 0.01 \\
\hline 12.00 & - \\
\hline 13.00 & - \\
\hline 14.00 & - \\
\hline 15.00 & 0.01 \\
\hline
\end{tabular}

Table 4-9. Distribution of quantity of fish consumed per eating occasion (g) by age and sex (from Pao et al., 1982).

\begin{tabular}{|l|l|l|l|l|l|l|l|l|l|}
\hline & & & \multicolumn{7}{|c|}{ Percentiles } \\
\hline Age (years) sex & Mean & SD & 5th & 25th & 50th & 75th & 90th & 95th & 99th \\
\hline & & & & & & & & & \\
\hline $1-2$ male-female & 52 & 38 & 8 & 28 & 43 & 58 & 112 & 125 & 168 \\
\hline $3-5$ male-female & 70 & 51 & 12 & 36 & 57 & 85 & 113 & 170 & 240 \\
\hline $6-8$ male-female & 81 & 58 & 19 & 40 & 72 & 112 & 160 & 170 & 288 \\
\hline $9-14$ male & 101 & 78 & 28 & 56 & 84 & 113 & 170 & 255 & 425 \\
\hline $9-14$ female & 86 & 62 & 19 & 45 & 79 & 112 & 168 & 206 & 288 \\
\hline $15-18$ male & 117 & 115 & 20 & 57 & 85 & 142 & 200 & 252 & 454 \\
\hline $15-18$ female & 111 & 102 & 24 & 56 & 85 & 130 & 225 & 270 & 568 \\
\hline $19-34$ male & 149 & 125 & 28 & 64 & 113 & 196 & 284 & 362 & 643 \\
\hline $19-34$ female & 104 & 74 & 20 & 57 & 85 & 135 & 184 & 227 & 394 \\
\hline $35-64$ male & 147 & 116 & 28 & 80 & 113 & 180 & 258 & 360 & 577 \\
\hline $35-64$ female & 119 & 98 & 20 & 57 & 85 & 152 & 227 & 280 & 480 \\
\hline $65-74$ male & 145 & 109 & 35 & 75 & 113 & 180 & 270 & 392 & 480 \\
\hline $65-74$ female & 123 & 87 & 24 & 61 & 103 & 168 & 227 & 304 & 448 \\
\hline $75+$ male & 124 & 68 & 36 & 80 & 106 & 170 & 227 & 227 & 336 \\
\hline $75+$ female & 112 & 69 & 20 & 61 & 112 & 151 & 196 & 225 & 360 \\
\hline Overall & 117 & 98 & 20 & 57 & 85 & 152 & 227 & 284 & 456 \\
\hline
\end{tabular}


The ingestion rate distribution for recreational fishermen was derived as follows:

$$
I_{\text {fish }}=\frac{M \times M S}{7 d \times w e e k^{-1}}
$$

where:

$I_{\text {fish }}=$ ingestion rate $(\mathrm{g} / \mathrm{d})$

$M=$ meals per week

$M S=$ meal size $(g)$

The ingestion rate $(\mathrm{g} / \mathrm{d})$ was calculated using the distributions described above for meals/week and meal size, in a Monte Carlo analysis. The resulting distribution of intake $(\mathrm{g} / \mathrm{d})$ is shown in Table 4-10 and Figure 4-2.

This distribution suggests approximately 3 times higher for adult male recreational fishermen in the Gulf of Mexico than recommended by EPA (USEPA, 1997) for all people consuming a recreational fisherman's catch.

Table 4-10. Summary statistics, ingestion rate distribution for adult recreational fishermen in the Gulf of Mexico.

\begin{tabular}{|l|c|}
\hline & Ingestion rate (g/d) \\
\hline Mean & 29 \\
Median & 20 \\
Standard deviation & 33 \\
$5^{\text {th }}$ percentile & 0 \\
$95^{\text {th }}$ percentile & 87 \\
\hline
\end{tabular}

Figure 4-2. Ingestion rate distribution for adult recreational fishermen in the Gulf of Mexico.

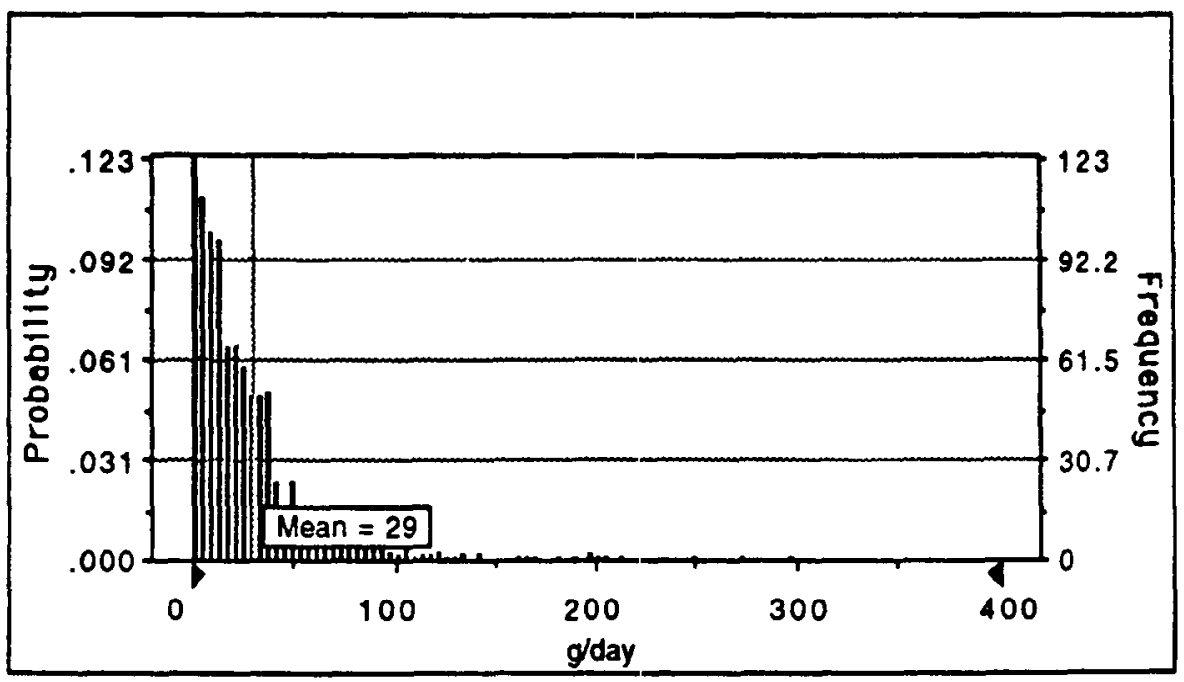




\section{OFFSHORE STUDY SITES AND RADIONUCLIDE CONCENTRATIONS IN SURFACE WATER}

\subsection{USDOE Field Study}

This risk assessment was coordinated with a USDOE project titled "Environmental and Economic Assessment of Discharges from Gulf of Mexico Region Oil and Gas Operations" (referred to as the "USDOE Field Study").

Continental Shelf Associates, Inc. (CSA) conducted the field study. The objective of the project was to increase the base of scientific knowledge concerning the following topics:

- The fate and environmental effects of contaminants found in produced water;

- the economic impacts of proposed regulations on offshore oil and gas producers of the Gulf of Mexico region; and

- the catch, consumption, and human use patterns of seafood species collected from coastal and offshore waters of the Gulf of Mexico.

The risk assessment presented here uses data collected in the USDOE field study of offshore study sites in Louisiana and Texas. This Section describes the sampling locations and methods, and summarizes ${ }^{210} \mathrm{~Pb},{ }^{226} \mathrm{Ra}$ and ${ }^{228} \mathrm{Ra}$ concentrations measured in water samples. Concentrations of radionuclides measured in edible finfish are described and analyzed in Section 6.

\subsection{Offshore Sampling Locations}

Samples were collected at eight discharging and 6 reference sites in the Gulf of Mexico (Figure 5-1; Table 5-1). Concentrations of metals, PAHs, and naturally occurring radioactive materials (NORM) were measured in the discharges, ambient water, sediments and organisms (Hart et al., 1996; Trefrey et al., 1996; CSA, 1997).

Discharging platforms were identified as primary and secondary sites. Primary sites represented platforms with produced water discharges with higher than average radionuclide loadings, and were sampled more intensely than the secondary sites.

Two sets of reference sites were included in the study. The first set of reference stations included a platform structure where produced water has never been discharged (SMI-229), and a natural reef (Sonnier Bank). The second set of reference sites are ambient reference sites selected to be representative of ambient conditions in the central and western Gulf of Mexico. 


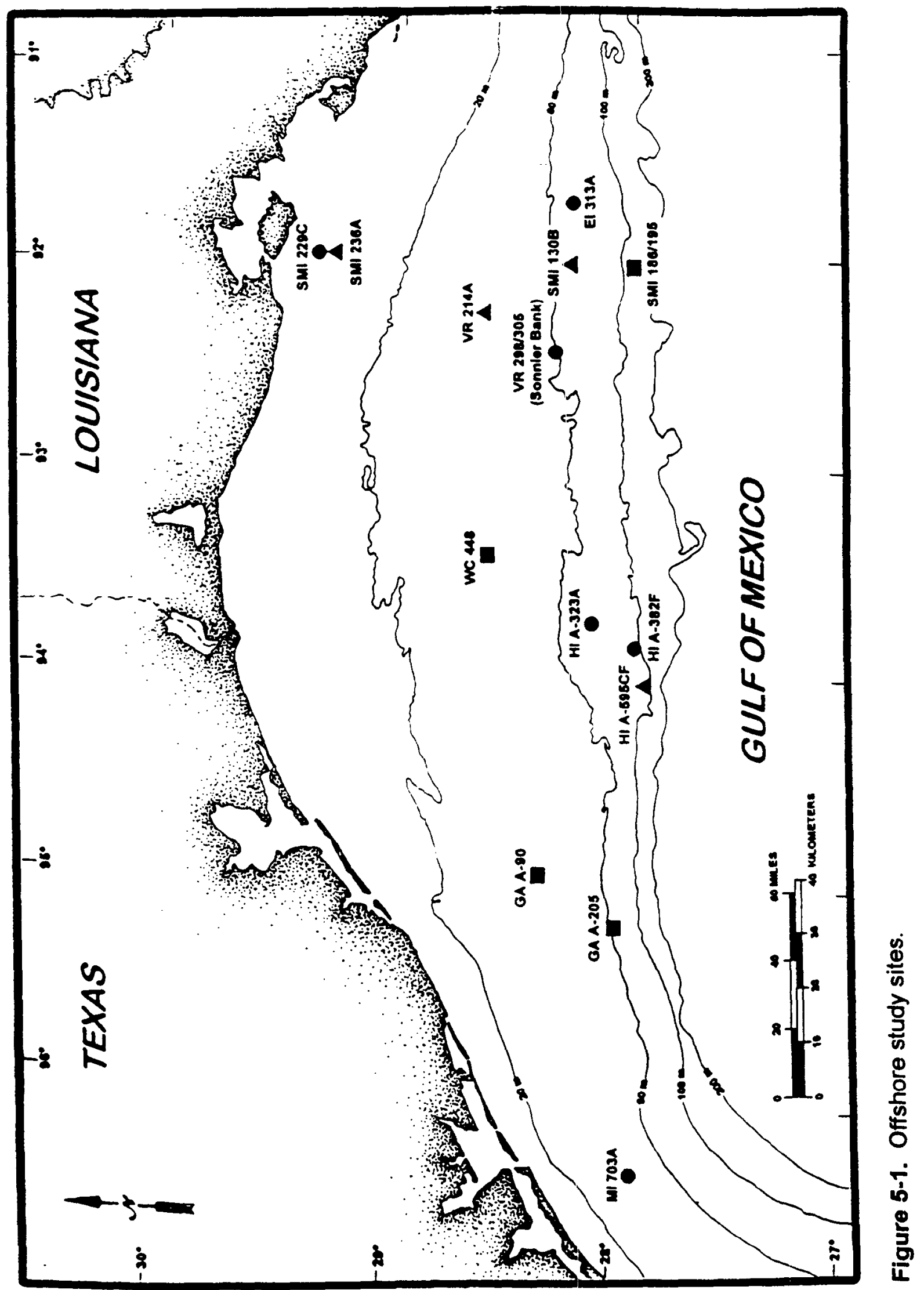


Table 5-1. Study site descriptions (modified from Hart et al., 1996).

\begin{tabular}{|c|c|c|c|}
\hline Study Site & Depth (m) & $\begin{array}{c}\text { Discharge } \\
\text { Rate } \\
\text { (bbl/d) }\end{array}$ & Oceanographic Conditions \\
\hline \multicolumn{4}{|l|}{ PRIMARY DISCHARGING } \\
\hline South Marsh Island 236A (SMI236) & 6.1 & 14800 & $\begin{array}{l}\text { Offshore Louisiana; } \\
\text { nearshore }\end{array}$ \\
\hline Vermillion 214A (VN214) & 38.7 & 8500 & $\begin{array}{l}\text { Offshore Louisiana; } \\
\text { mid-continental shelf }\end{array}$ \\
\hline South Marsh Island 130B (SMI130) & 65.5 & 22880 & $\begin{array}{l}\text { Offshore Louisiana; } \\
\text { mid-outer continental shelf }\end{array}$ \\
\hline High Island 595CF (HI595) & 121.9 & 5269 & $\begin{array}{l}\text { Offshore Texas; } \\
\text { outer continental shelf }\end{array}$ \\
\hline \multicolumn{4}{|l|}{ SECONDARY DISCHARGING } \\
\hline Matagorda Island 703 (M1703) & 50.9 & 250 & $\begin{array}{l}\text { Offshore Texas; } \\
\text { mid-continental shelf }\end{array}$ \\
\hline High Island 323A (HI323) & 71.6 & 621 & $\begin{array}{l}\text { Offshore Texas; } \\
\text { mid-outer continental shelf }\end{array}$ \\
\hline Eugene Island 313A (EI313) & 71.9 & 833 & $\begin{array}{l}\text { Offshore Louisiana; } \\
\text { mid-outer continental shelf }\end{array}$ \\
\hline High Island 382F (HI382) & 103.9 & 8818 & $\begin{array}{l}\text { Offshore Texas; } \\
\text { outer continental shelf }\end{array}$ \\
\hline \multicolumn{4}{|l|}{ NON-DISCHARGING STRUCTURES } \\
\hline South Marsh Island 229C (SMI229) & 5.5 & NA & $\begin{array}{l}\text { Offshore Louisiana, } \\
\text { nearshore }\end{array}$ \\
\hline $\begin{array}{l}\text { Vermillion } 298 \text { and } 305 \\
\text { (Sonnier Bank, SB) }\end{array}$ & 20.1 & NA & $\begin{array}{l}\text { Offshore Louisiana; } \\
\text { mid-continental shelf }\end{array}$ \\
\hline \multicolumn{4}{|l|}{ AMBIENT REFERENCE } \\
\hline West Cameron 448 (WC448) & 36.6 & NA & $\begin{array}{l}\text { Offshore Louisiana; } \\
\text { mid-continental shelf }\end{array}$ \\
\hline Galveston 90 (G90) & 40.2 & NA & $\begin{array}{l}\text { Offshore Texas; } \\
\text { mid-continental shelf }\end{array}$ \\
\hline $\begin{array}{l}\text { South Marsh Island 186/195 } \\
\text { (SMI186) }\end{array}$ & 64.0 & NA & $\begin{array}{l}\text { Offshore Louisiana; } \\
\text { mid-outer continental shelf }\end{array}$ \\
\hline Galveston 205 (G205) & 64.0 & NA & $\begin{array}{l}\text { Offshore Texas; } \\
\text { mid-outer continental shelf }\end{array}$ \\
\hline
\end{tabular}

NA: not applicable 
Radionuclides were measured only in organisms captured near the eight discharging sites and the two non-discharging reference structures (SMI229, Sonnier Bank). Because recreational fishermen routinely seek and eat piscivorous species, this assessment used concentrations of radionuclides measured in finfish only. Data describing concentrations of radionuclides measured in other organisms are reported in CSA (1997).

The data and descriptions of the study sites were abstracted from material provided by Continental Shelf Associates, Inc., and from published descriptions (Trefry et al., 1996; Hart et al., 1996; CSA, 1997).

\subsection{Sampling and Analytical Methods}

Samples were collected during June through August 1993. Produced water was sampled directly from the platform, and ambient water samples were collected $2000 \mathrm{~m}$ from the discharge.

To collect samples of plume water, rhodamine WT dye was injected into the produced water prior to discharge, and the center line of the plume was identified by fluorometric measurement. Plume samples were collected along the centerline of the plume, at 5, 10,30,50 and $100 \mathrm{~m}$ from the discharge point.

Finfish were collected using hook and line, traps and trawls. All trawling was conducted within $1,000 \mathrm{~m}$ of the discharge outfalls. Finfish species captured and analyzed for radionuclides at each study site are listed in Table 5-2.

Concentrations of radionuclides measured in finfish are presented in Section 6.

All tissue samples were stored frozen onboard the survey vessel. Where possible, finfish specimens were filleted to remove edible muscle tissue. CSA (1997), and Trefry et al., (1996) describe protocols for radionuclide analysis of water samples and biological tissues. 
Table 5-2. Finfish species sampled and analyzed for radionuclides.

\begin{tabular}{|l|l|}
\hline \multicolumn{2}{|c|}{ Finfish Species } \\
\hline Atlantic Croaker (whole) & Micropogonias undulatus \\
Atlantic Cutlassfish (whole) & Trichiurus lepturus \\
Black Drum (fillet, carcass) & Pogonias cromis \\
Flounders (fillet) & Bothidae \\
Gray Triggerfish (fillet, carcass) & Balistes capriscus \\
Greater Amberjack (fillet, carcass) & Seriola dumerili \\
Great Barracuda (fillet) & Sphyraena barracuda \\
Grunts (fillet) & Haemulidae \\
Hardhead Catfish (whole) & Arius felix \\
Lane Snapper (fillet, carcass) & Lutjanus synagris \\
Longspine Porgy (whole) & Stenotomus caprinus \\
Longtail Bass (fillet) & Hemanthias leptus \\
Pinfish (fillet) & Lagodon rhomboides \\
Red Snapper (fillet, carcass) & Lutjanus campechanus \\
Redfish (Red drum) (fillet) & Sciaenops ocellatus \\
Sea Bass (fillet, carcass) & Centropristis spp. \\
Speckled Trout (fillet, carcass) & Cynoscion neblosus \\
Trouts (whole) & Rhomboplites aurorubens \\
Vermillion Snapper (fillet, carcass) & Pristipomoides aqulonaris \\
Wenchman (whole) & Hemanthias leptus \\
\hline
\end{tabular}

\subsection{Concentrations of Radionuclides in Water}

Table 5-3 shows mean concentrations of ${ }^{226} \mathrm{Ra},{ }^{228} \mathrm{Ra}$ and ${ }^{210} \mathrm{~Pb}$ in the produced water discharges, the plume at $5 \mathrm{~m}$ from the discharge, and in ambient water $2000 \mathrm{~m}$ from the platforms.

Radionuclides discharged at these platforms disperse quickly, and are within or close to ambient levels 5 meters from the discharge. Background concentrations are variable and may be close to detection limits at some locations and at easily measurable levels at others. 
Table 5-3. Mean concentrations ( $\mathrm{pCi} / \mathrm{l}$ ) of radionuclides in produced water, the plume, and ambient water at the eight discharging sites.

\begin{tabular}{|c|c|c|c|c|c|c|c|c|c|}
\hline STATION & \multicolumn{3}{|c|}{ PRODUCED WATER } & \multicolumn{3}{|c|}{ PLUME (5m) } & \multicolumn{3}{|c|}{ AMBIENT WATER } \\
\hline & ${ }^{226} \mathrm{Ra}$ & ${ }^{228} \mathbf{R a}$ & ${ }^{210} \mathrm{~Pb}$ & ${ }^{226} \mathbf{R a}$ & ${ }^{228} \mathrm{Ra}$ & ${ }^{270} \mathrm{~Pb}$ & ${ }^{226} \mathrm{Ra}$ & ${ }^{228} \mathrm{Ra}$ & ${ }^{210} \mathbf{P b}$ \\
\hline \multicolumn{10}{|c|}{ Primary Discharging } \\
\hline SM1236 & 91 & 239 & 12.3 & 0.4 & 0.83 & 0.17 & $0.07-0.23$ & $0.1-3.2$ & $0.13-0.33$ \\
\hline V214 & 300 & 228 & 7.7 & 0.18 & 0.30 & 0.10 & $0.07-0.10$ & $0.3-1.0$ & $0.13-0.53$ \\
\hline SMI130 & 362 & 164 & 5.6 & 0.53 & 0.63 & 0.07 & $0.07-0.10$ & $0.13-1.67$ & $0.03-0.13$ \\
\hline HI595 & 1,494 & 356 & 12.5 & 0.93 & 2.20 & 0.53 & 0.03 & $0.53-1.20$ & $<0.20$ \\
\hline \multicolumn{10}{|c|}{ Secondary Discharging } \\
\hline M1703 & 56 & 69 & 2.6 & NS & NS & NS & NS & NS & NS \\
\hline HI323 & 112 & 162 & 5.2 & NS & NS & NS & NS & NS & NS \\
\hline$E / 313$ & 270 & 388 & 13.8 & NS & NS & NS & NS & NS & NS \\
\hline HI382 & 255 & 600 & 16.7 & NS & NS & NS & NS & NS & NS \\
\hline
\end{tabular}

NS: not sampled 


\section{RADIONUCLIDES IN EDIBLE FISH}

\subsection{Introduction}

Two issues must be addressed in assessing the human health risk associated with the ingestion of radionuclides in fish caught near platforms in the Gulf of Mexico. The first issue is the fish species used in the analysis, and whether they represent fish species that are actually caught and eaten by recreational fishermen. This is addressed in Section 6.2.

The second issue is the extent to which naturally occurring radionuclides measured in edible fish caught near the platforms are associated with produced water discharged from the platform as opposed to background levels. This is discussed in Section 6.3.

\subsection{Fish Species Used in the Analysis}

Fish species caught and analyzed during the DOE survey included species that are desirable target species, such as red snapper; species that may sometimes be eaten by fishermen (porgy); and species that are rarely or never eaten (e.g. cutlassfish). Most species were partitioned into edible and non-edible portions for analysis, while smaller specimens were analyzed whole (i.e. porgy, grunt). Table 6-1 shows the species caught and analyzed for radionuclides at each of the eight discharging platforms and two reference sites.

The fish species caught vary because the platforms are at different depths and experience different oceanographic conditions (Table 5-1). Species with different life histories and degree of association with the platform structure are also represented. Table $6-2$ lists the species sampled and the portions analyzed; describes their association with structures, and whether fishermen commonly eat them. Species used in the quantitative risk assessment (Section 9) are identified in Table 6-2. All species and portions were used in the conservative screening analysis (Section 8 ).

Only fish species and portions of fish assumed to be eaten by recreational fishermen were included in the quantitative risk assessment. The analysis assumed that the mix of fish caught during the DOE survey represents the mix of fish a recreational fishermen would eat at each platform. This assumption is uncertain, and probably leads to an overestimate of radionuclide intake for fishermen, because the more desirable fish species (snapper) have generally lower concentrations of radionuclides than do less desirable species (e.g. porgy). Porgy and croaker were also assumed to be eaten whole, because some fishermen do eat these species whole or use them in soup, but including these whole fish in the analysis is probably conservative because radium and lead tend to concentrate in bone and other inedible portions of fish. 
Table 6-1. Finfish species sampled at discharging and reference sites.

\begin{tabular}{|c|c|c|c|c|c|c|c|c|c|c|}
\hline \multirow[t]{2}{*}{ Species } & \multicolumn{8}{|c|}{ Produced Water Discharging Sites } & \multicolumn{2}{|c|}{$\begin{array}{c}\begin{array}{c}\text { Non-Discharging } \\
\text { Reference }\end{array} \\
\end{array}$} \\
\hline & $\mathrm{E} \mid 313$ & $\mathrm{H} 1323$ & HI382 & $\mathrm{HI595}$ & M1703 & SMI130 & SMI236 & V214 & SB & SMI229 \\
\hline \multicolumn{11}{|l|}{ Atlantic Croaker } \\
\hline \multicolumn{11}{|l|}{ Atlantic Cutlassfish } \\
\hline \multicolumn{11}{|l|}{ Black Drum } \\
\hline \multicolumn{11}{|l|}{ Flounders } \\
\hline Gray Triggerfish & 0 & - & O & O & ? & O & & 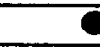 & & \\
\hline \multicolumn{11}{|l|}{ Greater Amberjack } \\
\hline \multicolumn{11}{|l|}{ Great Barracuda } \\
\hline \multicolumn{11}{|l|}{ Grunts } \\
\hline \multicolumn{11}{|l|}{ Hardhead Catfish } \\
\hline \multicolumn{11}{|l|}{ Lane Snapper } \\
\hline Longspine Porgy & 0 & 0 & O & 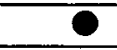 & & 0 & & 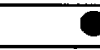 & & O \\
\hline \multicolumn{11}{|l|}{ Longtail Bass } \\
\hline Pinfish & O & O & O & 0 & P & O & & $\bar{C}$ & & \\
\hline Redfish & & & & & & & O & & & 0 \\
\hline Red Snapper & O & 2 & & & 0 & 0 & & 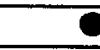 & & \\
\hline Sea Bass & 0 & $\overline{0}$ & 0 & 0 & O & 0 & & E & & \\
\hline Speckled Trout & & & & & & & 0 & & & 0 \\
\hline Trouts & & & & & & & 0 & & & 0 \\
\hline Vermillion Snapper & & 0 & & 0 & & 0 & & & & \\
\hline Wenchman & & & 0 & 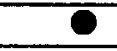 & & & O & & & 0 \\
\hline
\end{tabular}


Table 6-2. Fish species sampled and analyzed for radionuclides, shaded species and portions were used in the quantitative risk assessment.

\begin{tabular}{|c|c|c|c|c|}
\hline Finfish Species & Portion & Code $^{1}$ & Ecology & Eaten \\
\hline Aliantic croake- & Whole & 1 & not platform associated & YES, whole and fillets \\
\hline Atlantic Cutlassfish & whole & & not platform associated & NO \\
\hline 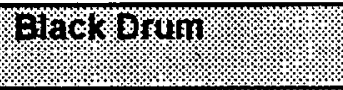 & $\begin{array}{l}\text { ffllet } \\
\text { carcass }\end{array}$ & 2 & not platform associated & YES, fillets \\
\hline Ffounds & mine & 3 & not platform associated & YES, fillets \\
\hline Gry Tiggerish & $\begin{array}{l}\text { Jllot } \\
\text { carcass }\end{array}$ & 4 & $\begin{array}{l}\text { common and tropically } \\
\text { dependent on platform }\end{array}$ & YES, fillets \\
\hline Srreater Mriberack & $\begin{array}{l}\text { Oillet } \\
\text { carcass }\end{array}$ & 5 & may be platform associated & YES, fillets \\
\hline Great Barracuda & fillet & & tropically dependent & NO \\
\hline Guthts & filles: & 6 & not platform associated & YES, fillets \\
\hline Hardhead Catfish & whole & & may be platform associated & NO \\
\hline Wne Snapper 1 , & $\begin{array}{l}\text { fillet: } \\
\text { carcass }\end{array}$ & 7 & $\begin{array}{l}\text { tropically dependent on } \\
\text { platform }\end{array}$ & YES, fillets \\
\hline Rongspinesorgy & Wholo & 8 & $\begin{array}{l}\text { not common or tropically } \\
\text { dependent }\end{array}$ & $\begin{array}{l}\text { YES, whole and fillets } \\
\text { Not a target species }\end{array}$ \\
\hline Yonglail/Bass & fillet & 9 & $\begin{array}{l}\text { associated with structure, } \\
\text { tropically dependent }\end{array}$ & YES, fillets \\
\hline Pinfish & fillet & & not associated with structure & NO \\
\hline Red Snapper & $\begin{array}{l}\text { fillet } \\
\text { carcass }\end{array}$ & 10 & $\begin{array}{l}\text { common and tropically } \\
\text { dependent }\end{array}$ & YES, fillets \\
\hline Redfísh (Red Drum) & frillet & 11 & not platform associated & YES, fillets \\
\hline Seabass .1 .1 .9$. & $\begin{array}{l}\text { fillet } \\
\text { carcass }\end{array}$ & 12 & common near structures & YES, whole and fillet \\
\hline Spoited Trouts & $\begin{array}{l}\text { Tillet:- } \\
\text { carcass }\end{array}$ & 13 & incidental & YES, fillets \\
\hline Trouts & whole & 14 & incidental & YES, whole and fillet \\
\hline Verminions snapper & $\begin{array}{l}\text { Finet } \\
\text { carcass }\end{array}$ & 15 & $\begin{array}{l}\text { common and tropically } \\
\text { dependent on structure }\end{array}$ & YES, fillets \\
\hline Wenchingn & Wholo & 16 & $\begin{array}{l}\text { common and tropically } \\
\text { dependent on structure }\end{array}$ & $\begin{array}{l}\text { YES, whole and fillets } \\
\text { Not a target species }\end{array}$ \\
\hline
\end{tabular}

'Code for statistical analyses and graphs, see section 6.3. 
A sensitivity analysis was run as part of an overall uncertainty analysis (section 10) to determine the extent to which these marginal species (porgy) influence the predicted cancer risks.

\subsection{Comparisons Among Sampling Locations and Fish Species}

Table 6-3 shows the mean concentrations of ${ }^{210} \mathrm{~Pb},{ }^{226} \mathrm{Ra},{ }^{228} \mathrm{Ra}$ in fish species used in the quantitative risk assessment.

Table 6-3. Concentrations of radionuclides in fish species used in the quantitative risk assessment.

\begin{tabular}{|c|c|c|c|}
\hline \multirow[t]{2}{*}{ STATION } & \multicolumn{3}{|c|}{$\begin{array}{c}\text { Concentration in Fish (pCi/g) } \\
\text { Mean (SD) }\end{array}$} \\
\hline & ${ }^{210} \mathbf{P b}$ & ${ }^{226} \mathrm{Ra}$ & ${ }^{228} \mathbf{R a}$ \\
\hline \multicolumn{4}{|l|}{ Discharging } \\
\hline$E \mid 313$ & $0.029(0.046)$ & $0.008(0.011)$ & $0.023(0.018)$ \\
\hline $\mathrm{HI} 323$ & $0.050(0.098)$ & $0.006(0.008)$ & $0.027(0.038)$ \\
\hline $\mathrm{HI} 382$ & $0.091(0.104)$ & $0.007(0.009)$ & $0.042(0.047)$ \\
\hline $\mathrm{HIS95}$ & $0.042(0.055)$ & $0.011(0.014)$ & $0.053(0.106)$ \\
\hline M1703 & $0.008(0.011)$ & $0.003(0.004)$ & $0.029(0.047)$ \\
\hline SMI130 & $0.035(0.051)$ & $0.006(0.007)$ & $0.043(0.046)$ \\
\hline SMI236 & $0.009(0.008)$ & $0.003(0.003)$ & $0.009(0.014)$ \\
\hline V214 & $0.017(0.012)$ & $0.005(0.005)$ & $0.018(0.029)$ \\
\hline \multicolumn{4}{|l|}{ Reference } \\
\hline Sonnier Bank & $0.029(0.035)$ & $0.012(0.015)$ & $0.018(0.036)$ \\
\hline SM1229 & $0.004(0.006)$ & $0.008(0.007)$ & $0.010(0.013)$ \\
\hline
\end{tabular}

Determining the impact from produced water discharges on the radionuclide concentrations measured in fish species near the platforms is a difficult task. Each platform discharges radionuclides into the Gulf of Mexico at different rates, and the receiving environment varies considerably (e.g. depths from 6 to $122 \mathrm{~m}$ ). This study has the advantage of having samples from two reference sites that include structures (platform and natural reef), so the fish species and oceanographic conditions will be at least comparable.

The radionuclides of concern in this analysis $\left({ }^{210} \mathrm{~Pb},{ }^{226} \mathrm{Ra}\right.$, and $\left.{ }^{228} \mathrm{Ra}\right)$ occur naturally in fish in the Gulf of Mexico, and concentrations will vary among locations, fish species, and fish sizes, with contributions to the variations from other unknown factors. The challenge is to apply statistical techniques to try and discern a difference between the concentrations of radionuclides in fish caught at the discharging platforms and those caught at the two reference stations. 
One problem encountered in the analysis is that large variations in radionuclide concentrations make it difficult to distinguish a difference between platforms. This large variation may be due mostly to the variation in radionuclide concentrations in one or two species, or reflect the fact that different species were caught at different platforms. Some species, particularly porgy, had consistently higher and more variable concentrations of radionuclides than did other species.

This analysis used One- and Two-way Analysis of Variance (ANOVA) and the Duncan's Multiple Range Test (SAS statistical package) to try to identify differences in radionuclide concentrations in fish between platforms, and between species.

\section{Differences Between Platforms}

Figure 6-1 shows a plot of the average ${ }^{210} \mathrm{~Pb},{ }^{226} \mathrm{Ra}$, and ${ }^{228} \mathrm{Ra}$ concentrations in fish species used in the risk assessment (see section 9). Concentrations at the reference stations (Sonnier Bank, SMI229) are at the low end of the range for the discharging platforms.

In this one-way ANOVA, the null hypothesis was that the average concentration of ${ }^{210} \mathrm{~Pb},{ }^{226} \mathrm{Ra}$ and ${ }^{228} \mathrm{Ra}$ for all fish species included in the quantitative risk assessment (see section 9) was equal at all 8 discharging platforms and two reference stations (SMI-229; Sonnier Bank).

For ${ }^{210} \mathrm{~Pb}$, the null hypothesis was rejected with confidence 0.05 ( $F$ value is 2.99 , and $p=0.0024$ ). For ${ }^{226} \mathrm{Ra}$, the null hypothesis was rejected with confidence 0.05 ( $F$ value is 2.04 , and $p=0.0370$. The null hypothesis was not rejected for ${ }^{228} \mathrm{Ra}$, with confidence 0.05 , but was rejected with confidence 0.1 ( $F$ value is 1.73 , and $p=0.0840$ ). 
Figure 6-1 Average concentrations of ${ }^{210} \mathrm{Fb},{ }^{226} \mathrm{Ra}$, and ${ }^{228} \mathrm{Ra}$ in fish species used in the quantitative risk analysis at two reference stations and eight discharging platforms.

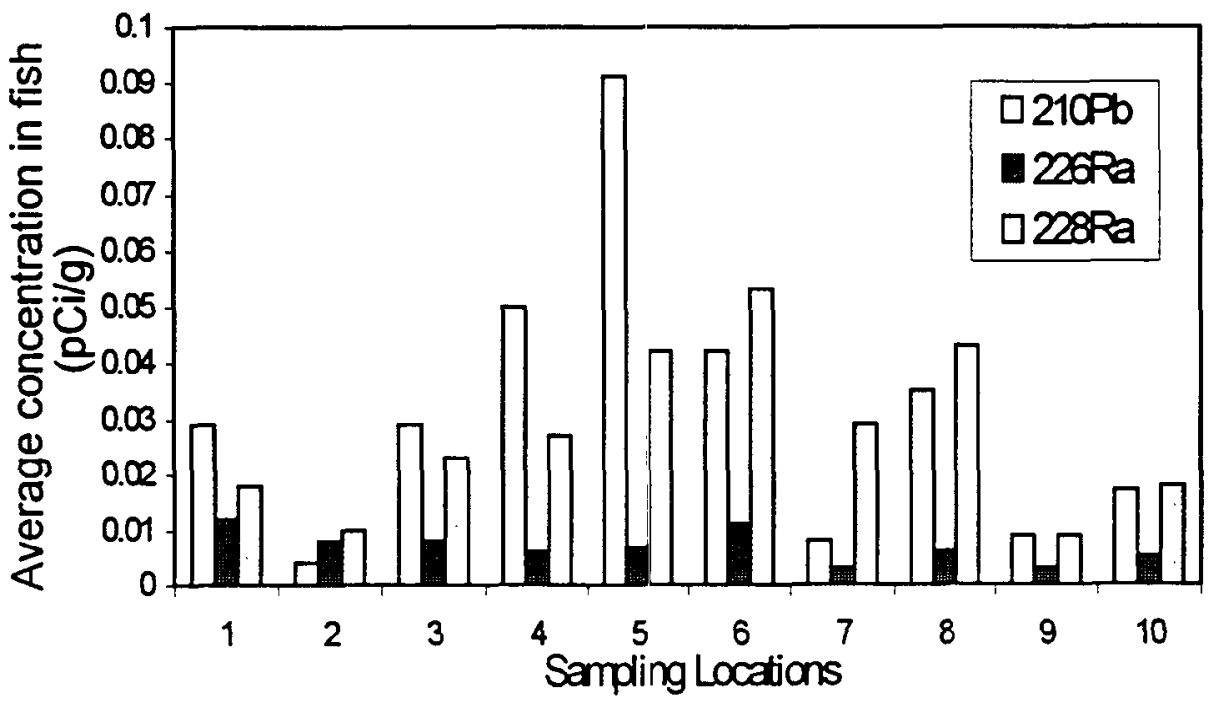

\begin{tabular}{|l|l|}
\hline \multicolumn{1}{|c|}{ Platform } & Code \\
\hline Sonnier Bank (REFERENCE) & 1 \\
\hline SM1229 (REFERENCE) & 2 \\
\hline E1313 & 3 \\
\hline$H 1323$ & 4 \\
\hline$H 1382$ & 5 \\
\hline$H 1595$ & 6 \\
\hline MI703 & 7 \\
\hline SMI130 & 8 \\
\hline SM1236 & 9 \\
\hline V214 & 10 \\
\hline
\end{tabular}


For the radionuclides for which the null hypothesis was rejected $\left({ }^{210} \mathrm{~Pb},{ }^{226} \mathrm{Ra}\right)$, the Duncan's multiple range test $(p=0.05)$ was used to group stations with relatively similar concentrations of contaminants in fishes. This post hoc test found that for ${ }^{210} \mathrm{~Pb}$, the concentration in fishes at platform HI382 was significantly higher than at the two reference locations (SMI229, Sonnier Bank). Concentrations of ${ }^{226} \mathrm{Ra}$ in Sonnier Bank fish were significantly different from those in fishes at platforms MI703 and SMI236, but concentrations in fish at reference platform SMI229 were not significantly different from any other platform.

\section{Differences Between Platforms and Species}

Inspection of the data suggests major variations in the ${ }^{210} \mathrm{~Pb}$ and ${ }^{226} \mathrm{Ra}$ concentrations between fish species (Figure 6-2). In particular, concentrations of ${ }^{210} \mathrm{~Pb}$ and ${ }^{226} \mathrm{Ra}$ in porgy are about an order of magnitude higher than in other fishes. ${ }^{228} \mathrm{Ra}$ concentrations do not appear to vary much between species (Figure 6-2). Plots of average concentrations in porgy and "all other fish" for the two reference locations and eight discharging platforms show that ${ }^{210} \mathrm{~Pb}$ and ${ }^{226} \mathrm{Ra}$ contamination in fishes is dominated by porgy, if porgy is present at a particular platform (Figure 6-3). This gives the basis of investigating the simultaneous impact of location and fish grouping (i.e. porgy and "all other fish") on ${ }^{210} \mathrm{~Pb}$ and ${ }^{226} \mathrm{Ra}$ concentrations.

A two-way ANOVA was used to test two hypotheses:

- Average ${ }^{210} \mathrm{~Pb}$ and ${ }^{226} \mathrm{Ra}$ concentrations in fish at all locations are equal; and

- Average contaminant concentrations in the two groups of fish (porgy and all other species) are equal.

Both hypotheses were rejected with confidence $0.05(p=0.0001)$ for ${ }^{210} \mathrm{~Pb}$ and ${ }^{226} \mathrm{Ra}$.

The Duncan multiple range test $(p=0.05)$ was used to group stations with relatively similar concentrations of contaminants in fishes for the radionuclides for which the null hypothesis was rejected $\left({ }^{210} \mathrm{~Pb},{ }^{226} \mathrm{Ra}\right)$. This post hoc test found that for ${ }^{210} \mathrm{~Pb}$, the concentrations in fishes at platforms $\mathrm{HI} 323$ and $\mathrm{HI} 382$ were significantly higher than at the two reference locations (SMI229, Sonnier Bank). Concentrations of ${ }^{210} \mathrm{~Pb}$ in porgy were significantly higher than in the "all other fish" group.

For ${ }^{226} \mathrm{Ra}$, the Duncan's multiple range test found that concentrations in fishes at Sonnier Bank were significantly higher than at all other locations except HI595. Concentrations of ${ }^{226} \mathrm{Ra}$ in fishes caught at reference station SMI229 were significantly different from (and higher than) concentrations at MI703 and SMI236. Concentrations of ${ }^{226} \mathrm{Ra}$ were significantly higher in porgy than in the "all other fish" group. 
Figure 6-2. Average concentrations of ${ }^{211} \mathrm{~Pb},{ }^{226} \mathrm{Ra}$, and ${ }^{228} \mathrm{Ra}$ in different fish species used in the quantitative risk analysis. Porgy is species number 8 , see Table 6-2 for number codes for other species.
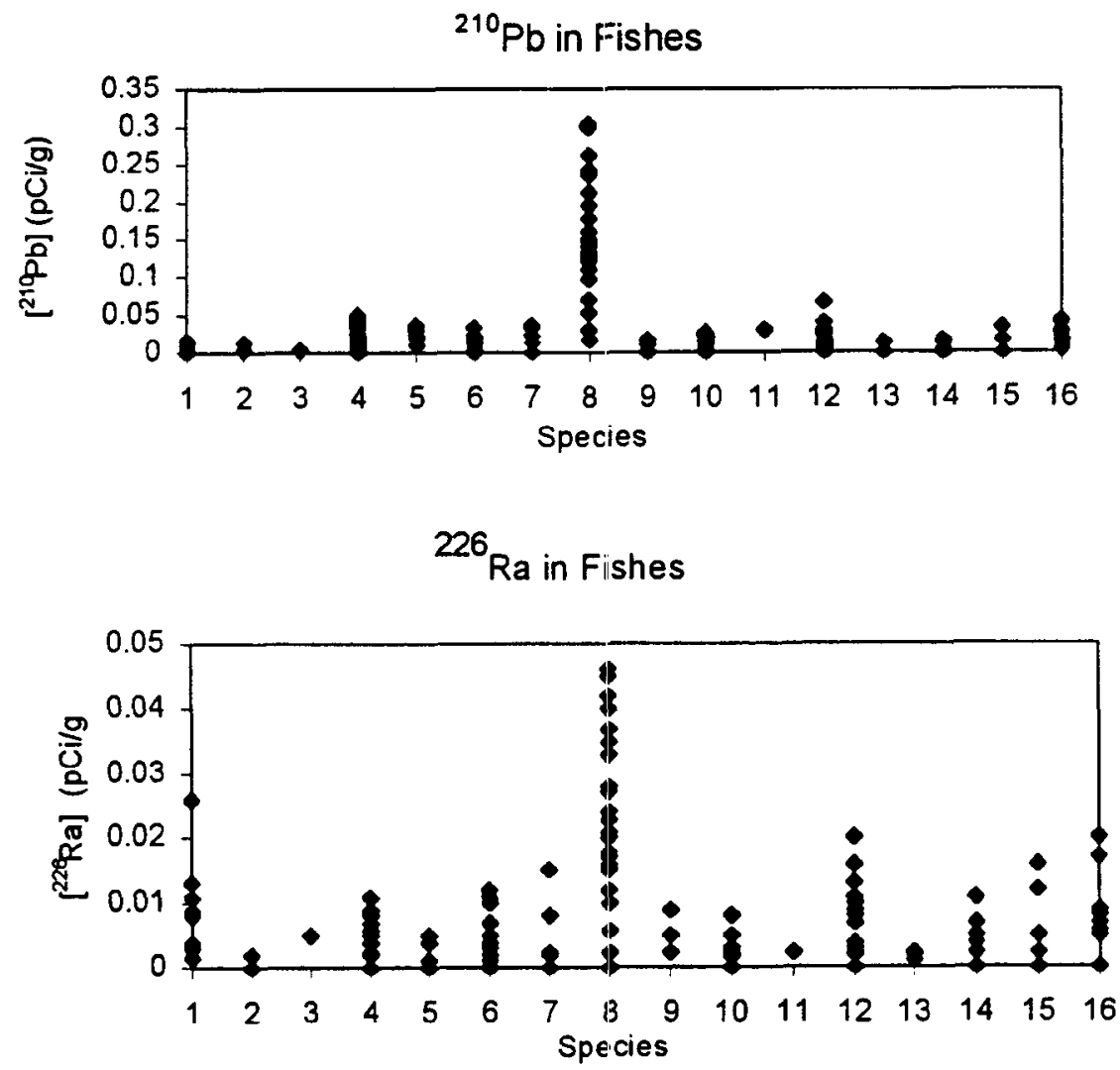

${ }^{228} \mathrm{Ra}$ in Fishes

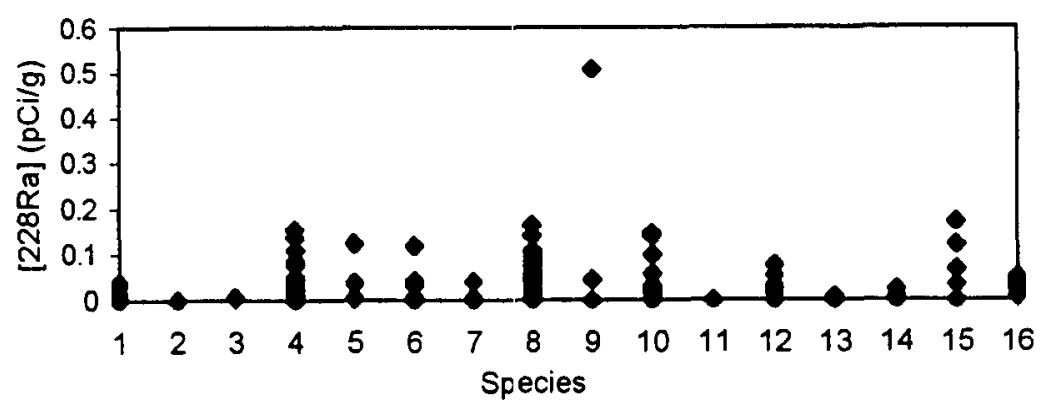


Figure 6-3. Average concentrations of ${ }^{210} \mathrm{~Pb}$, and ${ }^{226} \mathrm{Ra}$ in two groups of fishes (porgy and all other species used in the quantitative risk analysis).

${ }^{210} \mathrm{~Pb}$ in Porgy and Other Fishes

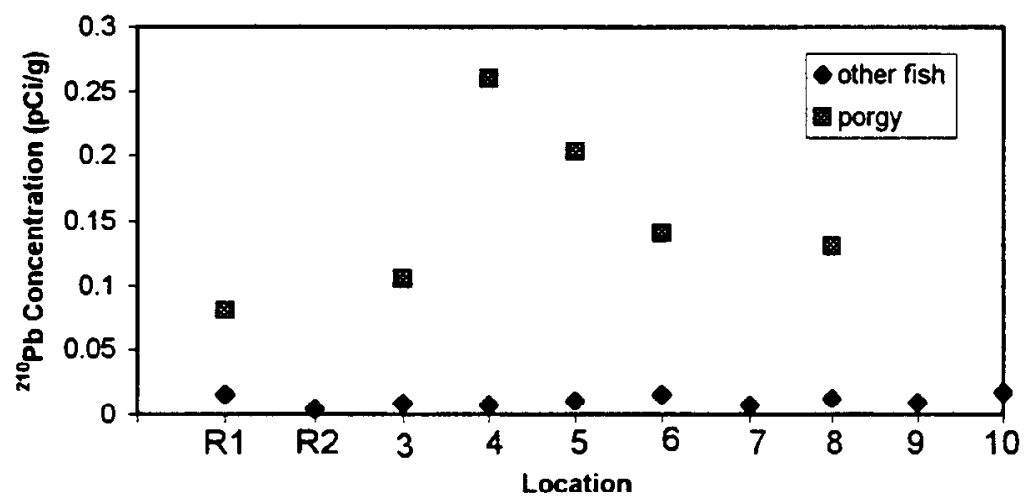

${ }^{226} \mathrm{Ra}$ in Porgy and Other Fish

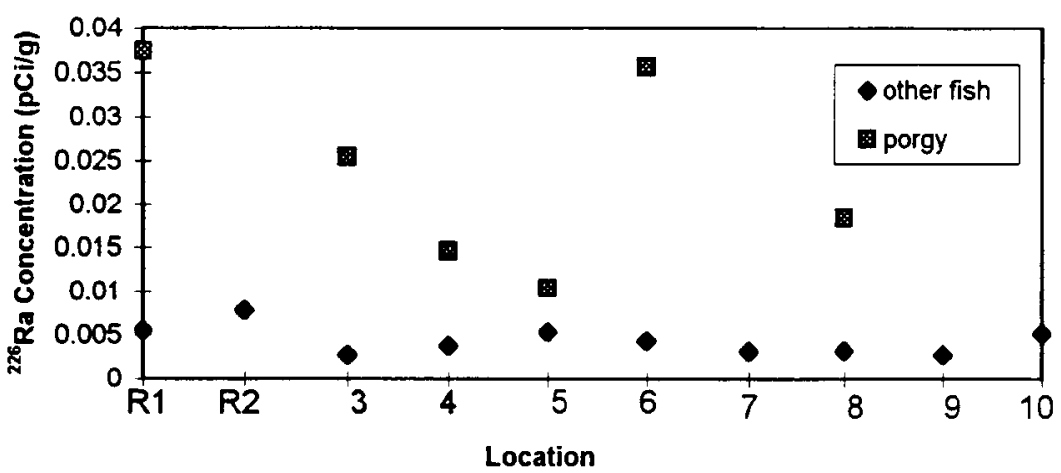

\begin{tabular}{|l|l|}
\hline \multicolumn{1}{|c|}{ Platform } & \multicolumn{1}{c|}{ Code } \\
\hline Sonnier Bank (REFERENCE) & 1 \\
\hline SMI229 (REFERENCE) & 2 \\
\hline EI313 & 3 \\
\hline H1323 & 4 \\
\hline HI382 & 5 \\
\hline H1595 & 6 \\
\hline M1703 & 7 \\
\hline SMI130 & 8 \\
\hline SMI236 & 9 \\
\hline V214 & 10 \\
\hline
\end{tabular}




\section{Differences Between Platforms for Lead in Porgy}

The graph for the average concentration of ${ }^{210} \mathrm{~Pb}$ (Figure 6-3) shows that the lowest concentrations of lead in porgy were in the fish collected at Sonnier Bank. A one-way ANOVA was done to identify whether the mean concentration at Sonnier Bank is significantly lower than at other sampling locations. The null hypothesis was that the average concentrations of ${ }^{210} \mathrm{~Pb}$ in porgy are equal at all sampling locations. The null hypothesis was rejected with confidence 0.05 (F value $13.28, p=0.0001$ ).

The Duncan's multiple-range test found that ${ }^{210} \mathrm{~Pb}$ concentrations in porgy at HI323, HI382 and HI595 are significantly higher than concentrations at Sonnier Bank (no porgy were sampled from reference platform SM1229).

\section{Discussion}

Significant differences were found between platforms for ${ }^{210} \mathrm{~Pb}$ and ${ }^{226} \mathrm{Ra}$, but these differences were not consistently between the two reference locations (Sonnier Bank and SMI229) and the discharging platforms.

Porgy had the highest and most variable concentrations of ${ }^{210} \mathrm{~Pb}$, and for porgy only, there were significant differences between locations. In general, most of the ${ }^{210} \mathrm{~Pb},{ }^{226} \mathrm{Ra}$ and ${ }^{228} \mathrm{Ra}$ found in fish at the platforms could be attributed mostly or completely to background levels. The exception to this result is for porgy - in this fish species, ${ }^{210} \mathrm{~Pb}$ is probably associated with the discharges at some locations.

This result for porgy is not unexpected given what is known about the bioconcentration of ${ }^{210} \mathrm{~Pb}$ in marine fishes. Reported bioconcentration factors for ${ }^{210} \mathrm{~Pb}$ are higher than for radium (IAEA, 1985). ${ }^{210} \mathrm{~Pb}$, like radium, concentrates in the bone, and the porgy analyzed were whole specimens.

These results suggest that use of porgy in the risk analysis will result in an overestimate of dose and risk to recreational fishermen, because porgy: had the highest and most variable ${ }^{210} \mathrm{~Pb}$ concentrations, were analyzed whole, and is not a target species for fishermen in the Gulf of Mexico. 


\section{DOSE-RESPONSE AND DOSE CONVERSION FACTORS}

\subsection{Introduction}

Current practice in radiation protection assumes there is a cancer risk associated with even small doses of radiation. To describe cancer risks associated with small exposures, epidemiological data associated with high doses and acute exposures are extrapolated down to low doses. This approach probably over-estimates risks at low doses.

Two methods are commonly used to estimate the risk associated with exposure to radionuclides ingested in food. The first estimates cancer incidence per $\mathrm{pCi}$ of lifetime intake using USEPA's slope factor. The other method uses dose conversion factors to calculate the effective dose (Sv or mrem) per intake. This dose can be converted to a lifetime risk estimate (fatal cancer, lifetime incidence or total detriment) using risk factors developed by ICRP (1991).

\subsection{Radiation Dose}

Traditional units in radiation dose measurements (i.e. $\mathrm{Ci}$, rad, rem) are being replaced by the International System (SI) of units (Bq, Gy, Sv). The names and units (traditional and $\mathrm{SI}$ ) for activity, absorbed dose and dose equivalent are given in Table 7-1. Prefixes commonly applied to these units are given in Table 7-2.

Table 7-1. Radiological names and units.

\begin{tabular}{|l|l|l|l|l|l|}
\hline \multicolumn{1}{|c|}{ Quantity } & \multicolumn{2}{c|}{ Traditional } & \multicolumn{2}{c|}{ SI } & Conversion \\
\hline & Name & \multicolumn{1}{c|}{ Unit } & Name & \multicolumn{1}{c|}{} \\
\hline & & & & & \\
\hline activity & curie (Ci) & $3.7 \times 10^{10} \mathrm{dis} / \mathrm{sec}$ & becquerel $(\mathrm{Bq})$ & $1 \mathrm{dis} / \mathrm{sec}$ & $1 \mathrm{~Bq}=2.7 \times 10^{-11} \mathrm{Ci}$ \\
\hline absorbed dose & $\mathrm{rad}(\mathrm{rad})$ & $100 \mathrm{erg} / \mathrm{gm}$ & gray $(\mathrm{Gy})$ & $1 \mathrm{~J} / \mathrm{kg}$ & $1 \mathrm{~Gy}=100 \mathrm{rad}$ \\
\hline $\begin{array}{l}\text { equivalent dose } \\
\text { effective dose }\end{array}$ & rem (rem) & $100 \mathrm{erg} / \mathrm{gm}$ & sievert $(\mathrm{Sv})$ & $1 \mathrm{~J} / \mathrm{kg}$ & $1 \mathrm{~Sv}=100 \mathrm{rem}$ \\
\hline
\end{tabular}

Table 7-2. Prefixes used in radiation protection.

\begin{tabular}{|c|c|}
\hline pico $(p)$ & $10^{-12}$ \\
\hline nano $(\mathrm{n})$ & $10^{-9}$ \\
\hline micro $(\mu)$ & $10^{-5}$ \\
\hline milli $(\mathrm{m})$ & $10^{-3}$ \\
\hline kilo $(\mathrm{k})$ & $10^{3}$ \\
\hline mega $(\mathrm{M})$ & $10^{6}$ \\
\hline giga $(\mathrm{G})$ & $10^{9}$ \\
\hline tera $(\mathrm{T})$ & $10^{12}$ \\
\hline
\end{tabular}


Radioactivity is quantified in terms of the number of spontaneous energy emitting transformations per unit time -- a quantity known as activity. An example of a transformation is the decay of a radium-226 nucleus into a radon222 nucleus, an alpha particle and gamma rays. The unit of activity has historically been the curie ( $\mathrm{Ci}$ ). One curie is equal to $3.7 \times 10^{10}$ disintegrations per second. In the SI system, the basic unit of activity has been redefined as one disintegration per second, known as the becquerel $(\mathrm{Bq})$. One curie is equal to $3.7 \times 10^{10} \mathrm{~Bq}$.

The biological effects of exposure to a radionuclide are related to the absorbed dose and dose rate. The absorbed dose is a measure of the energy imparted to matter. An absorbed dose of $100 \mathrm{erg} / \mathrm{grarn}$ is called $1 \mathrm{rad}$. In the SI system of units, the unit of absorbed dose is the Gray (Gy, 1 Joule/kilogram). An absorbed dose of $1 \mathrm{rad}$ is equal to $0.01 \mathrm{~Gy}$ ( $1 \mathrm{~Gy}=100$ rads).

The probability of stochastic effects (i.e. cancer and genetic effects) depends on the absorbed dose, the type and energy of the radiation causing the dose and the organs and tissues irradiated. Factors were developed by the International Commission on Radiological Protection (ICRP, 1991) to account for these relationships in humans.

Radiation weighting factors are used to account for the differences in relative biological effectiveness (RBE) of different radiations. The radiation weighting factor for gamma radiation $(\gamma)$ and beta $(\beta)$ particles has been assigned a value of 1 . The weighting factor for alpha $(\alpha)$ particles is set to 20 . The absorbed dose modified by the weighting factor is called the equivalent dose and is expressed in units of Joules per kilogram with the name Sievert (SV) given to 1 Joule/kg. The traditional unit is the rem (see Table 7-1). One Sievert is equal to $100 \mathrm{rem}$.

Tissue weighting factors are used to account for differences in the sensitivity to cancer induction of different human tissues and organs. A tissue weighting factor represents the relative contribution of that organ or tissue to the total effects resulting from uniform irradiation of the whole body. These factors are given in ICRP (1991). The equivalent dose weighted by these tissue weighting factors is referred to as the effective dose. For a uniform, whole body exposure, the equivalent and effective doses have the same value, and are both expressed in units of Sieverts (Sv).

For radionuclides that remain in the body (including radium and lead), the dose associated with a single intake is committed over a lifetime, because the radionuclides continue to cause an exposure. 


\subsection{Dose Conversion Factors}

Dose conversion factors relate intake ( $\mathrm{pCi}$ or $\mathrm{Bq}$ ) to dose (mrem or Sv) for a given radionuclide. This assessment used the dose conversion factors recommended by the ICRP (1994). These factors reflect new tissue and radiation weighting factors, and are available for specific age ranges (Table 7-3).

These dose conversion factors cause slight overestimates of dose and associated risk they commit doses beyond age 70 .

Table 7-3. Age-dependent dose conversion factors (equivalent dose to age 70 years, Sv/Bq; ICRP 1994).

\begin{tabular}{|c|c|c|c|}
\hline age at intake & ${ }^{210} \mathrm{~Pb}$ & ${ }^{226} \mathrm{Ra}$ & ${ }^{228} \mathrm{Ra}$ \\
\hline 3 months & $8.1 \times 10^{-6}$ & $4.7 \times 10^{-6}$ & $3.1 \times 10^{-5}$ \\
1 year & $3.6 \times 10^{-6}$ & $9.7 \times 10^{-7}$ & $6.0 \times 10^{-6}$ \\
5 years & $2.1 \times 10^{-6}$ & $6.2 \times 10^{-7}$ & $3.7 \times 10^{-6}$ \\
10 years & $1.9 \times 10^{-6}$ & $8.1 \times 10^{-7}$ & $4.1 \times 10^{-6}$ \\
15 years & $1.9 \times 10^{-6}$ & $1.5 \times 10^{-6}$ & $5.3 \times 10^{-6}$ \\
adult & $7.0 \times 10^{-7}$ & $2.8 \times 10^{-7}$ & $6.6 \times 10^{-7}$ \\
\hline
\end{tabular}

\subsection{Radiation Effects and Risk Factors}

The health effects of radionuclides can be attributed to their radioactive emissions. The alpha, beta and gamma radiation released by the decay of radionuclides cause ionization of cellular components, which may result in the mutation or death of affected cells. Environmental concentrations of radionuclides are expected to be associated with stochastic effects (cancer and genetic effects) rather than deterministic effects.

The major sources of data on stochastic effects are studies of the survivors of Hiroshima and Nagasaki, of patients exposed to radiation for medical treatment or diagnosis, and of groups of workers exposed to radiation at work (ICRP, 1991).

These studies are complex, and present many problems in analysis and interpretation. Exposures based on high doses and acute exposure must be applied to low level environmental exposures. The simplest relationship between an increment in dose and the probability of a stochastic effect is that of a straight line. There is evidence in simple organisms and for some animal tumors that the dose-effect relationship is curvilinear, and that the linear assumption may overestimate risk. 


\section{ICRP Risk Coefficients}

ICRP (1991) has, using the linear assumption, derived risk factors for cancer incidence and cancer mortality (Table 7-4). ICRP distinguishes between the risk coefficient for a worker and the general population.

Table 7-4. ICRP (1991) probability coefficients for stochastic effects.

\begin{tabular}{|l|c|c|}
\hline & Worker risk/Sv & Public risk/Sv \\
\hline Fatal cancer & $4.0 \times 10^{-2}$ & $5.0 \times 10^{-2}$ \\
Non-fatal cancer & $0.8 \times 10^{-2}$ & $1.0 \times 10^{-2}$ \\
Total cancer incidence & $4.8 \times 10^{-2}$ & $6.0 \times 10^{-2}$ \\
Severe hereditary effects & $0.8 \times 10^{-2}$ & $1.3 \times 10^{-2}$ \\
Total detriment & $5.6 \times 10^{-2}$ & $7.3 \times 10^{-2}$ \\
\hline
\end{tabular}

USEPA Slope Factors

Slope factors are derived using the USEPA RADRISK model and are "ageaveraged lifetime total incidence per unit intake" (Table 7-5; HEAST, 1995). Slope factors do not assume lifetime exposure. RADRISK incorporates a toxicokinetic model based upon alkaline earth intake, retention and excretion. RADRISK is a linear, no-threshold model that uses the sum of weighted organ doses to arrive at a single dose coefficient used to predict either the risk of getting a cancer or the risk of dying from cancer. RADRISK incorporates a lifetable analysis to adjust for age- and sex specific mortality from competing risks.

Table 7-5. USEPA slope factors.

\begin{tabular}{|c|c|}
\hline radionuclide & $\begin{array}{c}\text { slope factor } \\
\text { (incidence/pCi) }\end{array}$ \\
\hline & \\
\hline${ }^{210} \mathrm{~Pb}$ & $1.01 \times 10^{-9}$ \\
\hline${ }^{226} \mathrm{Ra}$ & $2.96 \times 10^{-10}$ \\
\hline${ }^{226} \mathrm{Ra}$ & $2.48 \times 10^{-10}$ \\
\hline
\end{tabular}




\section{SCREENING RISK ASSESSMENT}

\subsection{Introduction and Approach}

A screening assessment for human health risks from ingestion of ${ }^{210} \mathrm{~Pb},{ }^{226} \mathrm{Ra}$, and ${ }^{228} \mathrm{Ra}$ in fish caught near offshore study sites was done. This analysis followed the USEPA approach to estimating risks from carcinogens, by applying slope factors to conservative estimates of intake rates (USEPA, 1989).

Radium and ${ }^{210} \mathrm{~Pb}$ are naturally occurring radionuclides, and are present in background levels in water, sediment and organisms in the Gulf of Mexico. The screening assessment did not consider that some or all of the radionuclide measured in fish at a given site may reflect background levels.

The screening assessment was done to determine the need for a more accurate probabilistic analysis, and does not provide reasonable estimates of risk associated with radionuclides discharged in produced water.

\subsection{Screening Analysis}

\subsubsection{Screening Concentrations in Fish}

The methods used to obtain samples from fishes and the analyses of contaminant concentrations in those samples are described in Section 5. Concentrations of radium and ${ }^{210} \mathrm{~Pb}$ found in all finfish samples are given in Appendix B.

Table 8-1 summarizes the maximum radionuclide concentrations in finfish at each of the eight discharging platforms and two reference stations. These maximum concentrations in either whole fish, carcass, or edible flesh of the species sampled at each site were used in the screening assessment.

\subsubsection{Exposure Assessment}

USEPA methods for assessing Superfund sites were used to calculate screening intake rates for radionuclides in finfish caught near offshore produced water discharges (USEPA, 1989). 
Table 8-1. Maximum radionuclide concentrations ( $\mathrm{pCi} / \mathrm{g}$ wet weight) and screening cancer incidence risk for radionuclides in any fish species and parts of fishes at eight discharging platforms and two reference locations.

\begin{tabular}{|c|c|c|c|c|}
\hline STATION & \multicolumn{3}{|c|}{$\begin{array}{c}\text { Maximum Concentration in Fish } \\
\text { (pCi/g) }\end{array}$} & Screening Risk $^{\top}$ \\
\hline & ${ }^{210} \mathrm{~Pb}$ & ${ }^{226} \mathrm{Ra}$ & ${ }^{228} \mathrm{Ra}$ & \\
\hline Discharging & & & & \\
\hline El313 & 0.134 & 0.037 & 0.058 & $5.8 \times 10^{-4}$ \\
\hline HI323 & 0.303 & 0.040 & 0.146 & $1.3 \times 10^{-3}$ \\
\hline HI382 & 0.261 & 0.028 & 0.163 & $1.1 \times 10^{-3}$ \\
\hline HI595 & 0.162 & 0.042 & 0.507 & $1.1 \times 10^{-3}$ \\
\hline MI703 & 0.030 & 0.016 & 0.173 & $2.8 \times 10^{-4}$ \\
\hline SMI130 & 0.160 & 0.021 & 0.140 & $7.2 \times 10^{-4}$ \\
\hline SMI 236 & 0.036 & 0.011 & 0.092 & $2.2 \times 10^{-4}$ \\
\hline V214 & 0.040 & 0.015 & 0.119 & $2.7 \times 10^{-4}$ \\
\hline Reference & & & & \\
\hline Sonnier Bank & 0.126 & 0.046 & 0.154 & $6.4 \times 10^{-4}$ \\
\hline SMI229 & 0.018 & 0.026 & 0.036 & $1.2 \times 10^{-4}$ \\
\hline
\end{tabular}

${ }^{1}$ individual lifetime cancer incidence

Screening intakes of ${ }^{210} \mathrm{~Pb},{ }^{226} \mathrm{Ra}$ and ${ }^{228} \mathrm{Ra}$ were calculated as:

$$
I=C_{\text {fish }} \times I_{\text {fish }} \times F \times E F \times E D
$$

where:

$I=$ intake $(p C i)$

$\mathrm{C}_{\text {fish }}=$ concentration in finfish $(\mathrm{pCi} / \mathrm{g})$

$\mathrm{I}_{\text {fish }}=$ ingestion rate of self-caught fish (132. $\mathrm{g} / \mathrm{d}$; USEPA, 1989)

$F=$ fraction of fish from contaminated source (1.0)

$E F=$ exposure frequency ( $365 \mathrm{~d} /$ year; USEPA, 1989)

$E D=$ exposure duration (70 years; USEPA, 1989)

Exposure assumptions used in the screening analyses are conservative (90 and 95th percentile upper bound values), as described in USEPA (1989).

Concentrations in fish were the maximum measured in any species, in any part of the fish. These intake estimates are extremely conservative and are used here in a screening assessment to determine if an additional, more realistic and labor intensive effort is needed, not to estimate human health risks. 


\subsubsection{Risk Characterization}

Incremental lifetime cancer incidence risk (IR) was calculated by multiplying the estimated intake (I, pCi) by the USEPA slope factor (SF, risk per $\mathrm{pCi}$, Table 7-5). Screening IR values greater than $1 \times 10^{-6}$ suggest a need for further quantitative assessment of carcinogenic risk.

$$
I R=I \times S F
$$

\subsection{Screening Results}

Table 8-1 shows the screening lifetime cancer risks for the eight discharging platforms and the two reference locations. All screening risks were greater than $1 \times 10^{-4}$ and suggest the need for further analysis. Note that the screening risk estimates for the reference locations were also greater than $1 \times 10^{-4}$. These screening risks were used to determine the need for additional, more realistic and labor intensive analyses, and not to estimate human health risks. 


\section{QUANTITATIVE RISK ASSESSMENT}

A more realistic and quantitative assessment was done to estimate the distributions of committed dose and cancer incidence risk, for adult recreational fishermen who eat fish caught near produced water discharging platforms in the Gulf of Mexico.

\subsection{Intake}

\subsubsection{Concentrations in Edible Fish}

The analysis used measured concentrations of ${ }^{210} \mathrm{~Pb},{ }^{226} \mathrm{Ra}$ and ${ }^{228} \mathrm{Ra}$ in edible flesh and in whole fish of species likely to be eaten by fishermen. Fish species and parts of fish used in the analysis are described in Section 6.

Over an extended period a fisherman is expected to catch and eat a range of fishes with contaminant concentrations that would approach a central tendency. Therefore, normal distributions of concentrations were assumed, and in each distribution the standard error of the mean was substituted for the standard deviation of the data (Seiler and Alvarez, 1996) in the Monte Carlo calculations. Where necessary, the lower limits of the distributions were truncated at zero. Table 9-1 summarizes these distributions. This approach is more realistic than assuming that some fishermen always eat the maximum or minimum concentrations of a contaminant measured in fish at a particular platform. The original data are given in Appendix B.

Concentrations reported as qualitative because they were near or below the method detection limit (MDL) were included in the analysis at one-half the value of the reported MDL. Because these small values near or below the MDL were reported, other concentrations reported as non-detected (ND) were treated as zero in the distributions.

In most cases fish concentrations of individual radionuclides were not highly correlated (Table 9-2). In the Monte Carlo analysis used to calculate exposure and risk, these concentration distributions were assumed to be independent. 
Table 9-1. Normal distributions of radionuclide concentrations in fish used in the quantitative risk assessment.

\begin{tabular}{|l|l|l|l|}
\hline STATION & \multicolumn{3}{|c|}{$\begin{array}{c}\text { Concentration in Fish (pCi/g) } \\
\text { Mean (SEM) }\end{array}$} \\
\hline & \multicolumn{1}{|c|}{${ }^{210} \mathrm{~Pb}$} & ${ }^{226} \mathrm{Ra}$ & ${ }^{228} \mathrm{Ra}$ \\
\hline & & & \\
\hline Discharging & & & \\
\hline El313 & $0.029(0.009)$ & $0.008(0.002)$ & $0.023(0.004)$ \\
\hline HI323 & $0.050(0.018)$ & $0.006(0.001)$ & $0.027(0.007)$ \\
\hline HI382 & $0.091(0.030)$ & $0.007(0.003)$ & $0.042(0.013)$ \\
\hline HI595 & $0.042(0.011)$ & $0.011(0.003)$ & $0.053(0.022)$ \\
\hline MI703 & $0.008(0.003)$ & $0.003(0.001)$ & $0.029(0.012)$ \\
\hline SMI130 & $0.035(0.010)$ & $0.006(0.001)$ & $0.043(0.009)$ \\
\hline SMI236 & $0.009(0.002)$ & $0.003(0.001)$ & $0.009(0.004)$ \\
\hline V214 & $0.017(0.017)$ & $0.005(0.001)$ & $0.018(0.006)$ \\
\hline Reference & & & \\
\hline Sonnier Bank & $0.029(0.007)$ & $0.008(0.002)$ & $0.018(0.007)$ \\
\hline SMI229 & $0.004(0.002)$ & $0.012(0.003)$ & $0.010(0.004)$ \\
\hline
\end{tabular}

SEM: standard error of the mean

Table 9-2. Correlation coefficients between radionuclide concentrations in fishes.

\begin{tabular}{|c|c|c|c|}
\hline \multirow[t]{2}{*}{ STATION } & \multicolumn{3}{|c|}{ Correlation Coefficient } \\
\hline & ${ }^{226} \mathrm{Ra}:{ }^{210} \mathrm{~Pb}$ & ${ }^{228} \mathrm{Ra}:{ }^{210} \mathrm{~Pb}$ & ${ }^{228} \mathrm{Ra}:{ }^{226} \mathrm{Ra}$ \\
\hline \multicolumn{4}{|l|}{ Discharging } \\
\hline $\mathrm{E} / 313$ & 0.82 & 0.07 & 0.23 \\
\hline $\mathrm{H} 1323$ & 0.45 & 0.50 & 0.19 \\
\hline $\mathrm{H} 1382$ & 0.36 & 0.49 & 0.87 \\
\hline $\mathrm{H} 1595$ & 0.91 & 0.03 & 0.10 \\
\hline M1703 & 0.52 & 0.08 & 0.11 \\
\hline SMI130 & 0.87 & 0.35 & 0.44 \\
\hline SMI236 & 0.06 & 0.24 & 0.37 \\
\hline V214 & 0.21 & 0.14 & 0.18 \\
\hline \multicolumn{4}{|l|}{ Reference } \\
\hline Sonnier Bank & 0.82 & 0.35 & 0.20 \\
\hline SM1229 & 0.79 & 0.67 & 0.48 \\
\hline
\end{tabular}




\subsubsection{Intake Calculation}

Exposure duration (ED) was assumed to be the adult life of recreational fishermen, from age 19 to age 70 (52 years). This is a conservative assumption, and in reality exposure duration may range from several years to a lifetime. One alternative is to use data describing the length of time a person spends living at one place. This approach, however, is likely to underestimate exposure duration, because most people are likely to move to an area close by, and are likely to continue their fishing habits.

A sensitivity analysis was done (Section 10) to determine the importance of this assumption to the final results. An analysis was also done assuming exposure for a single year, to calculate annual doses.

The analysis used the distributions ( $g / d$ ) derived in Section 4 , for intake of selfcaught fish by adult recreational fishermen. The analysis conservatively assumed that $100 \%(F=1)$ of a recreational fisherman's intakes are from fishing near a discharge.

Intake distributions of contaminants were calculated using the USEPA method as described in Section 8, Equation 2, with exposure parameters as shown in Table 9-3. The calculations were done using a Monte Carlo analysis.

Calculated intake distributions are summarized in Table 9-4.

Table 9-3. Parameters used to calculate intake distributions.

\begin{tabular}{|l|l|}
\hline \multicolumn{1}{|c|}{ Parameter } & \multicolumn{1}{c|}{ Value or Distribution } \\
\hline Cfish: concentration in fish (pCi/g) & Table 9-1 \\
Ifish: ingestion rate of self-caught fish $(\mathrm{g} / \mathrm{d})$ & Table 4-10 \\
F: fraction of fish from contaminated source & 1.0 \\
ED: exposure duration $(\mathrm{y})$ & adult lifetime: 52 years; \\
annual dose:1 year & $365 \mathrm{~d} / \mathrm{y}$ (USEPA, 1989) \\
\hline
\end{tabular}


Table 9-4. Lifetime intake ( $\mathrm{pCi}$ ) distributions of radionuclides in fish caught near eight discharging platforms and two reference structures.

\begin{tabular}{|l|l|l|l|l|l|l|}
\hline STATION & \multicolumn{7}{|c|}{$\begin{array}{c}\text { Total Lifetime Intake (pCi) } \\
\text { Mean (SD) }\end{array}$} \\
\hline & \multicolumn{2}{|c|}{${ }^{210} \mathrm{~Pb}$} & \multicolumn{2}{c|}{${ }^{228}$ Ra } & ${ }^{228}$ Ra \\
\hline & mean & $95 \%$ & mean & $95 \%$ & mean & $95 \%$ \\
\hline Discharging & & & & & & \\
\hline El313 & $1.6 \times 10^{4}$ & $5.5 \times 10^{4}$ & $4.6 \times 10^{3}$ & $1.5 \times 10^{4}$ & $1.3 \times 10^{4}$ & $4.2 \times 10^{4}$ \\
\hline HI323 & $2.9 \times 10^{4}$ & $9.7 \times 10^{4}$ & $3.4 \times 10^{3}$ & $1.2 \times 10^{4}$ & $1.6 \times 10^{4}$ & $5.4 \times 10^{4}$ \\
\hline HI382 & $5.1 \times 10^{4}$ & $1.8 \times 10^{5}$ & $4.0 \times 10^{3}$ & $1.5 \times 10^{4}$ & $2.4 \times 10^{4}$ & $8.0 \times 10^{4}$ \\
\hline HI595 & $1.4 \times 10^{4}$ & $8.2 \times 10^{4}$ & $6.3 \times 10^{3}$ & $2.2 \times 10^{4}$ & $3.1 \times 10^{4}$ & $1.0 \times 10^{5}$ \\
\hline MI703 & $4.6 \times 10^{3}$ & $1.5 \times 10^{4}$ & $1.7 \times 10^{3}$ & $6.0 \times 10^{3}$ & $1.7 \times 10^{4}$ & $5.5 \times 10^{4}$ \\
\hline SMI130 & $2.0 \times 10^{4}$ & $7.3 \times 10^{4}$ & $2.2 \times 10^{3}$ & $1.1 \times 10^{4}$ & $2.5 \times 10^{4}$ & $8.3 \times 10^{4}$ \\
\hline SMI236 & $5.1 \times 10^{3}$ & $1.7 \times 10^{4}$ & $1.7 \times 10^{3}$ & $5.9 \times 10^{3}$ & $5.2 \times 10^{3}$ & $1.7 \times 10^{4}$ \\
\hline V214 & $1.3 \times 10^{4}$ & $4.9 \times 10^{4}$ & $2.9 \times 10^{3}$ & $9.9 \times 10^{3}$ & $1.0 \times 10^{4}$ & $3.7 \times 10^{4}$ \\
\hline Reference & & & & & & \\
\hline Sonnier Bank & $1.6 \times 10^{4}$ & $5.4 \times 10^{4}$ & $6.8 \times 10^{3}$ & $2.3 \times 10^{4}$ & $1.0 \times 10^{4}$ & $3.6 \times 10^{4}$ \\
\hline SMI229 & $2.0 \times 10^{3}$ & $8.3 \times 10^{3}$ & $4.5 \times 10^{3}$ & $1.5 \times 10^{4}$ & $5.8 \times 10^{3}$ & $2.1 \times 10^{4}$ \\
\hline
\end{tabular}

SD: standard deviation

\subsection{Effective Dose}

Intakes from ingestion of fish, expressed in $\mathrm{pCi}$, were converted to $\mathrm{Bq}$ by multiplying the values by 0.037 . Distributions of effective dose (Sv) were calculated by multiplying the dose conversion factor ( $\mathrm{Sv} / \mathrm{Bq}$ ) by the distributions of radionuclide intakes in units of $\mathrm{Bq}$.

Dose conversion factors used were those for adults given in ICRP (1994), (Table $7-3$ ). Effective doses for ${ }^{210} \mathrm{~Pb},{ }^{226} \mathrm{Ra}$ and ${ }^{228} \mathrm{Ra}$ were summed for each platform.

\subsection{Cancer Risk}

Cancer incidence risk was estimated from the estimated effective dose distributions (Sv) and the ICRP (1991) cancer incidence risk factor for the public (Table 7-4).

$$
I R=D \times R F
$$

where:

$\mathrm{IR}=$ individual incremental lifetime cancer incidence risk

$D=$ effective dose (Sv)

$\mathrm{RF}=\mathrm{ICRP}$ cancer incidence risk factor (risk per Sv) 


\subsection{Results}

Estimated annual and lifetime dose distributions for ${ }^{210} \mathrm{~Pb},{ }^{226} \mathrm{Ra}$ and ${ }^{228} \mathrm{Ra}$ are given in Table 9-5. Summary figures, showing mean, minimum and maximum doses for each platform are presented in Figures 9-1 and 9-2. The mean, minimum and maximum lifetime cancer risk incidence is shown in Figure 9-3.

The percent probability that total lifetime cancer incidence risk exceeds specified values $\left(1 \times 10^{-}, 1 \times 10^{-5}, 1 \times 10^{-4}\right)$ is shown for each platform in Table 9-7.

Table 9-5. Estimated annual and lifetime effective dose (mSv) distributions for adult recreational fishermen from ${ }^{210} \mathrm{~Pb},{ }^{226} \mathrm{Ra}$ and ${ }^{228} \mathrm{Ra}$.

\begin{tabular}{|l|l|l|l|l|}
\hline \multirow{2}{*}{ STATION } & \multicolumn{2}{|c|}{$\begin{array}{c}\text { ANNUAL DOSE } \\
\text { (mSv) }\end{array}$} & \multicolumn{2}{c|}{$\begin{array}{c}\text { LIFETIME DOSE } \\
\text { (mSv) }\end{array}$} \\
\cline { 2 - 5 } & mean & $95 \%$ & mean & $95 \%$ \\
\hline Discharging & & & & \\
\hline El313 & 0.02 & 0.05 & 0.86 & 2.7 \\
\hline HI323 & 0.02 & 0.08 & 1.2 & 4.0 \\
\hline HI382 & 0.04 & 0.13 & 2.0 & 7.2 \\
\hline H1595 & 0.03 & 0.10 & 1.5 & 5.8 \\
\hline M1703 & 0.01 & 0.04 & 0.57 & 1.9 \\
\hline SMI130 & 0.02 & 0.08 & 1.2 & 4.1 \\
\hline SMI236 & 0.01 & 0.02 & 0.30 & 1.0 \\
\hline V214 & 0.01 & 0.05 & 0.65 & 2.4 \\
\hline Reference & & & & \\
\hline Sonnier Bank & 0.02 & 0.05 & 0.84 & 2.7 \\
\hline SMI229 & 0.01 & 0.02 & 0.31 & 1.0 \\
\hline
\end{tabular}

${ }^{1}$ to get dose in units of mrem, multiply by 100 .

${ }^{2}$ ICRP(1991) and NCRP (1993) suggested annual dose limit for the public is $1 \mathrm{msv} / \mathrm{y}$.

${ }^{3} \mathrm{NCRP}$ (1993) suggested annual dose limit for the public for a single source is $0.25 \mathrm{msv} / \mathrm{y}$. 
Table 9-6. Individual lifetime cancer incidence risk for adult recreational fishermen from ${ }^{210} \mathrm{~Pb},{ }^{226} \mathrm{Ra}$ and ${ }^{228} \mathrm{Ra}$ in fish.

\begin{tabular}{|c|l|l|}
\hline \multirow{2}{*}{ STATION } & \multicolumn{2}{|c|}{ RISK: } \\
& \multicolumn{2}{|c|}{ CANCER INCIDENCE } \\
\hline Discharging & & $95^{1 \mathrm{n}}$ percentile \\
\hline EI313 & $5.2 \times 10^{-5}$ & \\
\hline HI323 & $7.2 \times 10^{-5}$ & $1.6 \times 10^{-4}$ \\
\hline HI382 & $1.2 \times 10^{-4}$ & $2.4 \times 10^{-4}$ \\
\hline HI595 & $9.2 \times 10^{-5}$ & $4.3 \times 10^{-4}$ \\
\hline MI703 & $3.4 \times 10^{-5}$ & $3.0 \times 10^{-4}$ \\
\hline SMI130 & $7.3 \times 10^{-5}$ & $1.2 \times 10^{-4}$ \\
\hline SM1236 & $1.8 \times 10^{-5}$ & $2.5 \times 10^{-4}$ \\
\hline V214 & $3.9 \times 10^{-5}$ & $6.1 \times 10^{-4}$ \\
\hline Reference & & $1.4 \times 10^{-4}$ \\
\hline Sonnier Bank & $5.0 \times 10^{-5}$ & \\
\hline SMI229 & $1.9 \times 10^{-5}$ & $1.6 \times 10^{-4}$ \\
\hline
\end{tabular}

Table 9-7 Percent probability that lifetime cancer risk incidence from ${ }^{210} \mathrm{~Pb}$, ${ }^{226} \mathrm{Ra}$ and ${ }^{228} \mathrm{Ra}$ in fish is greater than or equal to specified risk values $\left(1 \times 10^{-6}\right.$, $\left.1 \times 10^{-5}, 1 \times 10^{-4}\right)$.

\begin{tabular}{|l|c|c|c|}
\hline & \multicolumn{3}{|c|}{ Percent Probability } \\
\hline \hline Discharging & $\geq 1 \times 10^{-6}$ & $\geq 1 \times 10^{-5}$ & $\geq 1 \times 10^{-4}$ \\
\hline El313 & & & 13 \\
\hline HI323 & 93 & 82 & 21 \\
\hline HI382 & 100 & 87 & 40 \\
\hline HI595 & 100 & 89 & 31 \\
\hline MI703 & 100 & 73 & 6 \\
\hline SMI130 & 93 & 87 & 22 \\
\hline SMI 236 & 100 & 53 & 1 \\
\hline V214 & 92 & 75 & 9 \\
\hline Reference & 93 & & 14 \\
\hline Sonnier Bank & & 82 & 2 \\
\hline SMI229 & 94 & 55 & \\
\hline
\end{tabular}


Figure 9-1. Mean, minimum and maximum annual estimated doses (mSv/y) to adult recreational fishermen from ingestion of ${ }^{210} \mathrm{~Pb},{ }^{226} \mathrm{Ra}$ and ${ }^{228} \mathrm{Ra}$ in fish caught near eight discharging platforms and two reference sites in the Gulf of Mexico.

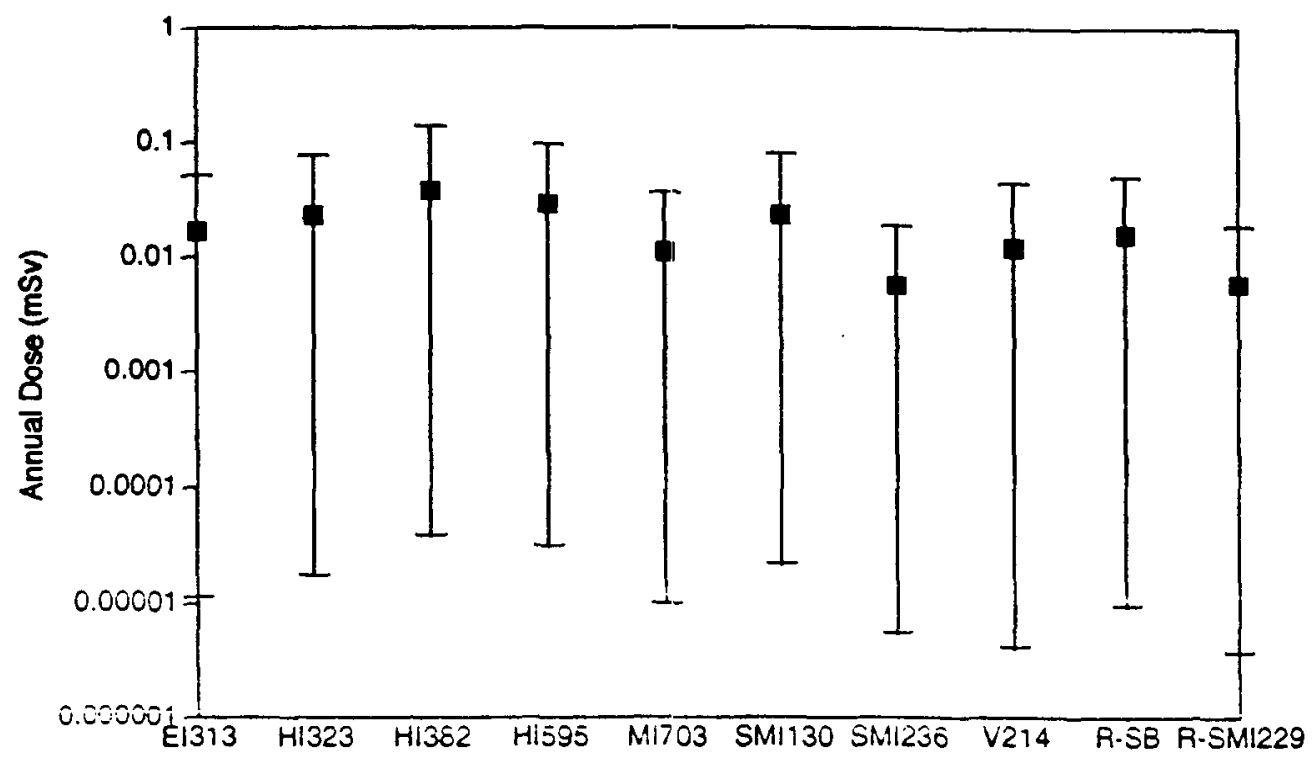

Figure 9-2. Mean, minimum and maximum lifetime estimated doses (mSv) to adult recreational fishermen from ingestion of ${ }^{210} \mathrm{~Pb},{ }^{226} \mathrm{Ra}$ and ${ }^{228} \mathrm{Ra}$ in fish caught near eight discharging platforms and two reference sites in the Gulf of Mexico.

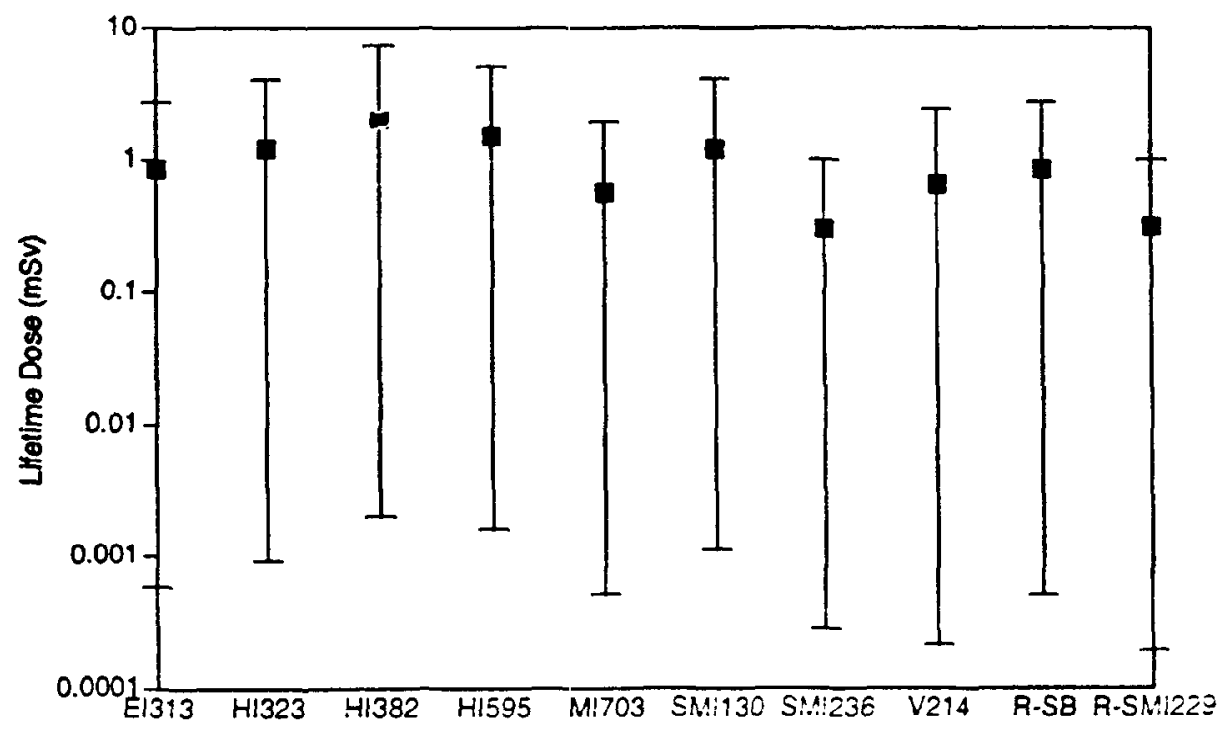


Figure 9-3. Mean, minimum and maximum estimated lifetime cancer incidence risk to adult recreational fishermen from ingestion of ${ }^{210} \mathrm{~Pb},{ }^{226} \mathrm{Ra}$ and ${ }^{228} \mathrm{Ra}$ in fish caught near eight discharging platforms and two reference sites in the Gulf of Mexico.

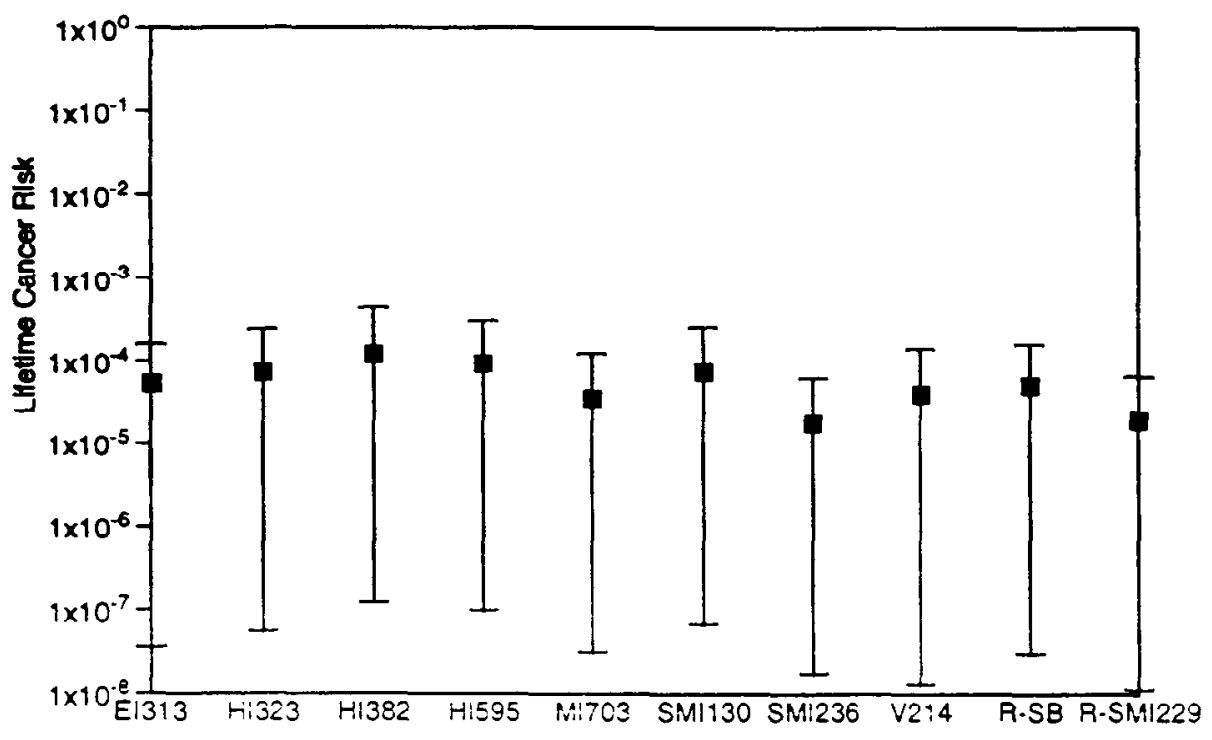

Doses and risks for the eight discharging platforms are similar to those for the two reference sites. Estimated annual doses are all well below the ICRP (1991) and NCRP suggested $1 \mathrm{mSv} / \mathrm{y}$ for the public and the $0.25 \mathrm{mSv} / \mathrm{y}$ from a single source suggested by NCRP (1993).

Mean individual lifetime cancer incidence risks for all platforms except $\mathrm{H} 1382$ are less than the $1 \times 10^{-4}$ level commonly considered acceptable by USEPA. The risks associated with ingestion of fish caught at the two reference sites are within the range for seven of the eight discharging sites (HI382 is larger). This suggests that some or all of the radionuclides in fish at the produced water discharging platforms are associated with background.

The mean risk for HI382 just exceeds the $1 \times 10^{-4}$ level, and if some radionuclides in fish at $\mathrm{HI} 382$ are assumed to be associated with background sources rather than the produced water discharge, (i.e. the levels at Sonnier Bank or SMI 229) risks at $\mathrm{HI} 382$ are also within acceptable risk range. Risks at HI382 are dominated by ${ }^{210} \mathrm{~Pb}$ in porgy, a species that is eaten by recreational fishermen but is not a target species. The estimated annual dose at $\mathrm{HI} 382$ is 
only $4 \%$ of the ICRP recommended limit for the public, and $16 \%$ recommended by NCRP for a single source.

The analysis assumed that recreational fishermen caught all of their fish near oil and gas platforms and that the population at risk is fishermen that fish exclusively near structures. Fishermen who fish both close to and away from oil and gas structures will have smaller risks associated with produced water discharges. It was also assumed that all of the intake of these fishermen was from fish caught near these platforms. 


\section{UNCERTAINTY ANALYSIS}

\subsection{Introduction}

Two major sources contribute to the uncertainty in the final dose and risk estimates presented in Section 9. The first is the natural variability or heterogeneity associated with some parameters, particularly those which relate to human behavior or characteristics (e.g. amount of seafood ingested). This kind of uncertainty can be better described through data collection and data analysis, but cannot be eliminated. The second source of uncertainty in the final dose and risk estimates results from a lack of knowledge concerning a parameter (e.g. dose conversion factor, risk factor). These sources of uncertainty can also be reduced through data collection and analysis.

Uncertainties associated with the assumptions used in this analysis include the intake of contaminants by recreational fishermen, exposure duration, and the dose-response relationships used in calculating risks.

Uncertainties in annual intake were included in the assessment by describing concentrations in fish and fish intake rates, as distributions in the Monte Carlo analysis. A sensitivity analysis for these probabilistic assumptions (size of a fish meal, number of fish meals per week, concentrations of radionuclides in fishes) shows that these assumptions are major contributors to the variance of the overall risk estimates (Figure 10-1).

Because of a lack of knowledge or data, a number of assumptions were not treated probabilistically. These assumptions are those for which deterministic, single value assumptions were made, including exposure duration and radionuclide dose conversion and risk factors. These uncertainties have varying effects on the results of the risk assessment, and it is important to specifically identify and discuss the impacts of these uncertainties and conservative assumptions on the results.

\subsection{Uncertainties in Exposure Estimates}

A major uncertainty in the risk assessment is in the assumptions used in the exposure analysis, including:

- concentrations of radionuclides in fishes caught near platforms;

- the amount of self-caught fish a recreational fishermen ingests;

- the mix of species a recreational fisherman catches and eats; and

- the duration of exposure. 
Figure10-1. Example of major contributions to the variance of the overall risk assessment $\left({ }^{210} \mathrm{~Pb}\right.$ in fishes at $\mathrm{HI} 382$, as determined by Crystal Ball $\left.{ }^{\mathrm{TM}}\right)$.

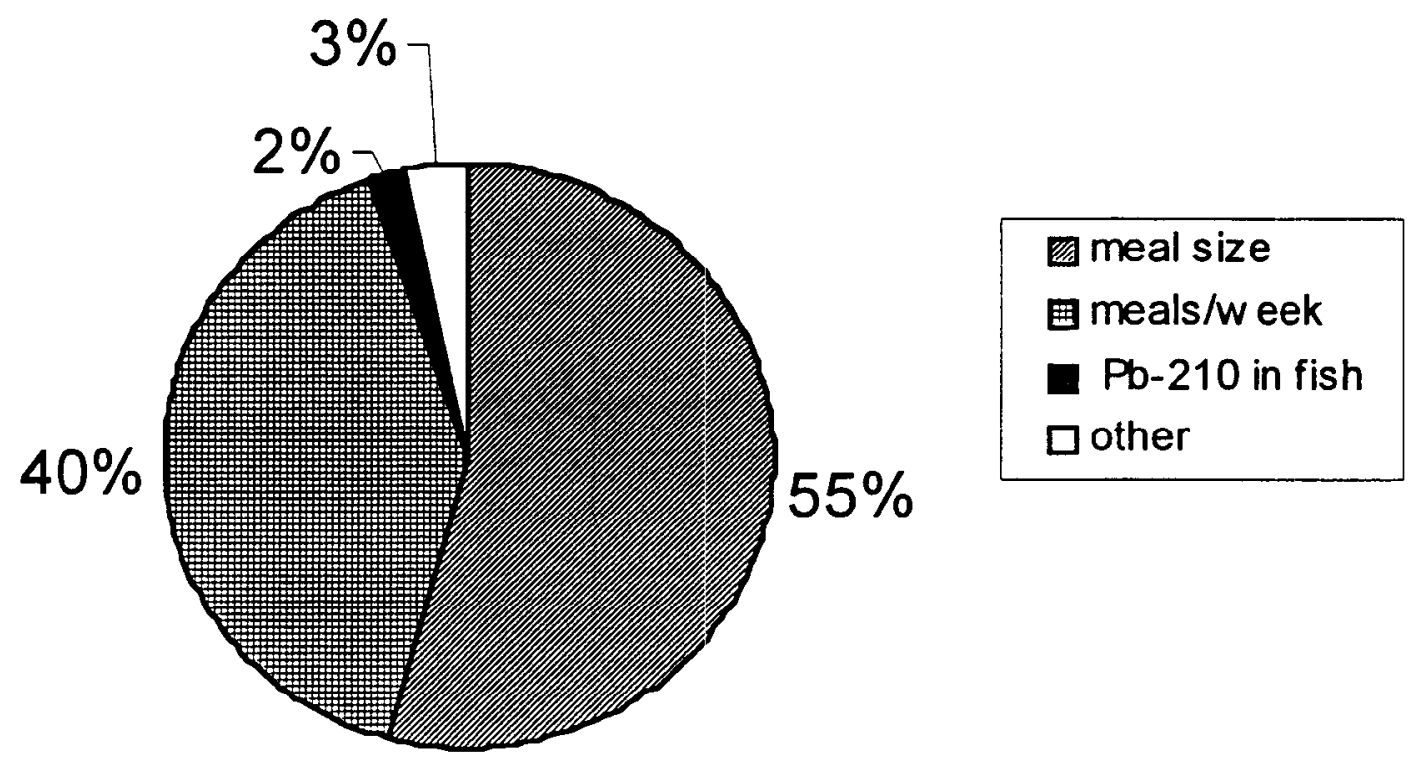

\subsubsection{Uncertainties in Concentrations in Fish and Fish Species Eaten by Fishermen}

The concentrations of radionuclides in fishes caught near the platforms are uncertain. A small number of samples (12-30) were used to establish the distributions of radionuclide concentrations in fish at each location. The DOE field program reduced the detection limits for radionuclides in fishes below the levels reported in other studies, but measured concentrations were often close to or less than MDLs, as well as being close to average background levels.

Small sample sizes and incorrect weighting of the species in terms of which are most likely to actually be eaten, could lead to major under- or overestimates of radionuclide concentrations in fish.

The species caught at each platform (Table 6-2) include species likely to be trophically associated with the platform structure (grey triggerfish), species that are resident near platforms but not completely trophically dependent on them (red snapper, vermillion snapper) and species that are probably not residents (croaker, trout). It was assumed that the fish that were sampled are representative of what recreational fishermen catch at each location. 
If a fisherman preferentially ate fish that are resident or trophically associated with the platform, the amount of contaminant ingested could be higher than estimated in the risk assessment. Since the trophically dependent fish species and other fish with high concentrations of radionuclides are generally not the preferred target fish species for recreational fishermen, intake and risk was probably overestimated. Another conservative assumption embedded in the analysis was the assumption that recreational fishermen ate whole porgy and croakers caught near the platforms. Porgy was the dominant species in terms of radionuclide concentrations (see section 6 ), but these fish are not preferred target species in the Gulf of Mexico.

A sensitivity analysis was done to compare the risks estimated using preferred target species to the risks estimated when whole porgy was included. This sensitivity analysis was done using platforms that had data for the same set of species: fillets of gray triggerfish, red snapper, sea bass (all identified as "target species") and whole porgy.

Table 10-1 shows the risk estimates for these platforms using all fish species sampled at each platform, the identified species common to this subset of platforms (gray triggerfish, red snapper, sea bass, whole porgy), the target species common to this subset (i.e. porgy excluded) and porgy alone.

Table 10-1. Sensitivity analysis, for species used in calculation of risk; mean individual lifetime cancer incidence risk to adult recreational fishermen from ingestion of ${ }^{210} \mathrm{~Pb},{ }^{226} \mathrm{Ra}$ and ${ }^{228} \mathrm{Ra}$ in self-caught fish.

\begin{tabular}{|l|c|c|c|c|}
\hline & El313 & HI323 & SMl130 & Sonnier Bank \\
\hline $\begin{array}{l}\text { All species used in } \\
\text { the risk assessment }\end{array}$ & $5 \times 10^{-5}$ & $7 \times 10^{-5}$ & $7 \times 10^{-5}$ & $5 \times 10^{-5}$ \\
\hline All common species & $6 \times 10^{-5}$ & $1 \times 10^{-4}$ & $8 \times 10^{-5}$ & $6 \times 10^{-5}$ \\
\hline $\begin{array}{l}\text { All common species, } \\
\text { exclude porgy }\end{array}$ & $3 \times 10^{-5}$ & $3 \times 10^{-5}$ & $4 \times 10^{-5}$ & $3 \times 10^{-5}$ \\
\hline Porgy only & $1 \times 10^{-4}$ & $3 \times 10^{-4}$ & $2 \times 10^{-4}$ & $1 \times 10^{-5}$ \\
\hline
\end{tabular}

species common to this subset of platforms: gray triggerfish, sea bass, red snapper, and porgy.

Risks associated with ingestion of radionuclides in porgy were always higher, by approximately an order of magnitude, This result suggests that the assumption that fishermen eat whole porgy probably results in an overestimate of risk because porgy has high concentrations of NORM and is not a target species. 


\subsubsection{Quantity of Self Caught Fish Ingested by Recreational Fishermen}

The estimated average intake derived in Section 4 (Table 4-10) is approximately three time higher than the rates recommended by USEPA based on the NMFS (1993) data. However, the survey done in the DOE study specifically asked recreational fishermen how many meals per week they ate self-caught fish.

The variance of the estimate of the quantity of fish ingested by recreational fishermen is predominated by the variance of two distributions: the amount of fish eaten per meal (meal size) and the frequency of fish meals.

The estimate of meal size yielded a contribution to the variance of the overall risk estimates that was approximately twice that of all other distributions combined. These data were based on an analysis of the 1977-1978 survey (Pao et al., 1982) and are probably representative of the US population, and of the range of fish meal sizes eaten by adult men.

Most of the remaining variance (approximately $40 \%$ of total) comes from the distribution of meals/week derived from data collected in the survey of recreational fishermen done as part of the USDOE field study. These data have some uncertainty associated with them, because not all fishermen were sampled, and because it was based on an individual's estimate of the number of fish meals eaten. However, since these data are based on a survey of fishermen in the Gulf of Mexico, and because the results were very similar for all groups considered (i.e. Texas and Louisiana; offshore and coastal fishermen; see section 4), most of the variance in the estimate is probably due to the true variability in number of self-caught fish meals eaten.

An assumption made in the analysis is that the fisherman of concern fishes only at the structures discharging produced water. This is a conservative assumption, because even fishermen who say they fish exclusively at oil and gas structures are not likely to always fish at the same one, or to always fish at structures with active produced water discharges.

\subsubsection{Duration of Exposure}

Because of the lack of available data on exposure period, adult recreational fishermen were assumed to eat self-caught fish for their entire adult lives (age 19-70; 52 years). This assumption is a conservative one, but is within reasonable bounds - fishermen have reported fishing for 1-5 to 66-70 years (Table 4-3). Most fishermen probably fish and eat their catch for a shorter period of time. A sensitivity analysis was done to determine the importance of this assumption in the overall risk estimates. Table 10-2 shows the results for exposure periods of $5,10,20,30,40$ and 52 years for a single platform (HI382). There is a linear relationship between increased risk with increasing duration of 
recreational fishing activity; up to an order of magnitude of difference between 5 and 52 years of fishing.

Table 10-2. Sensitivity analysis example (HI382) for exposure duration.

\begin{tabular}{|c|c|c|}
\hline $\begin{array}{l}\text { Exposure period } \\
\text { (years) }\end{array}$ & \multicolumn{2}{|c|}{ Individual lifetime cancer incidence risk } \\
\hline & mean & 95th Percentile \\
\cline { 2 - 3 } 5 & $1.1 \times 10^{-5}$ & $3.5 \times 10^{-5}$ \\
10 & $2.3 \times 10^{-5}$ & $7.0 \times 10^{-5}$ \\
20 & $4.6 \times 10^{-5}$ & $1.4 \times 10^{-4}$ \\
30 & $6.9 \times 10^{-5}$ & $2.1 \times 10^{-4}$ \\
40 & $9.1 \times 10^{-5}$ & $2.8 \times 10^{-4}$ \\
52 & $1.2 \times 10^{-4}$ & $3.7 \times 10^{-4}$ \\
\hline
\end{tabular}

\subsection{Uncertainties in Identifying Produced Water Impacts}

Identifying the impacts of produced water discharges on fishes living close to the platforms, and therefore on recreational fishermen eating those fish, was difficult because there are background concentrations of radionuclides in fishes that have nothing to do with a particular discharge. These background concentrations vary in space and time.

Significant differences were found between platforms for ${ }^{210} \mathrm{~Pb}$ and ${ }^{226} \mathrm{Ra}$, but these differences were not consistently between the two reference locations (Sonnier Bank and SMI229) and the discharging platforms.

Porgy had the highest and most variable concentrations of ${ }^{210} \mathrm{~Pb}$, and for porgy only, there were significant differences between locations. In general, most of the ${ }^{210} \mathrm{~Pb},{ }^{226} \mathrm{Ra}$ and ${ }^{228} \mathrm{Ra}$ found in fish at the platforms could be attributed mostly or completely to background levels. The exception to this result is for porgy - in this fish species, some ${ }^{210} \mathrm{~Pb}$ at some locations is probably platform associated.

These results suggest that use of porgy in the risk analysis will result in an overestimate of dose and risk to recreational fishermen, because porgy: had the highest and most variable ${ }^{210} \mathrm{~Pb}$ concentrations, were analyzed whole, and is not a target species for fishermen in the Gulf of Mexico.

The cancer risks of interest are incremental risks - that is the risks associated with the discharges alone. However, the risks estimated are the total risks associated with ingestion of ${ }^{210} \mathrm{~Pb},{ }^{226} \mathrm{Ra}$ and ${ }^{228} \mathrm{Ra}$ in fish caught near the studied locations. 


\subsection{Uncertainties in Dose-Response}

There is uncertainty associated with both the dose-conversion factors and the risk factors used in this analysis to relate iritake to dose and cancer risk. Uncertainties in dose conversion factors result from the natural variation in human beings in the way radioactive materials move through the body, and in uncertainties in the individual's age at exposure and length of exposure. This assessment used standard, deterministic values for dose conversion factors developed for the average population. These dose conversion factors commit the dose from bone seekers like radium and lead beyond the length of a human life, and so probably slightly overestimate close. They are well documented and widely used.

The risk factors used are also standard, internationally accepted values (ICRP, 1991). NCRP (1997) estimated the uncertainty associated with the risk factors used to estimate risk at low doses and low-dose rates. This analysis considered five components of uncertainty in the risk coefficient (risk/Sv): epidemiological uncertainties; dosimetrical uncertainties; population transfer model; projection to lifetime; and extrapolation to low dose or low-dose rate exposure. NCRP (1997) concluded that the values of lifetime risk per Sv can range from about one-fourth to about twice the nominal value, with a mean that is lower than the nominal value.

One way to deal with these uncertainties in dose and risk is to use the same values to estimate risks associated with background concentrations of radionuclides in fishes, which are similar to those for fish caught near discharging platforms. 


\section{CONCLUSIONS}

Fish caught near most platforms had concentrations of radionuclides that were very similar to concentrations in fish caught at two reference sites in the Gulf of. Mexico. The platform with the highest predicted dose and risks had annual doses that were $4 \%$ of the recommended pubic exposure from all sources and $16 \%$ of the recommended exposure from a single source for an adult recreational fishermen. This platform had a mean predicted lifetime cancer incidence risk of $1.2 \times 10^{-4}$. Most or all of this risk could be associated with background concentrations of radionuclides.

Assumptions used in this risk assessment may contribute to an overestimate of risk. These include inclusion of whole porgy in the analysis; and the assumption of lifetime exposure.

Concentrations of radium measured in fish caught near platforms are probably not platform associated. Lead-210, particularly in porgy (or other whole fish) may be partially associated with the produced water discharges at some locations.

Recreational fishermen and their families are expected to face a negligible risk of carcinogenic effects from ingesting radionuclides in fishes caught near the sampled produced water discharges. 


\section{REFER.ENCES}

Anderson, A.C. and J.C. Rice, 1992, A Survey of Fish and Shellish Consumption by Residents of the Greater New Orieans Area, Louisiana Department of Environmental Quality Contract 24400-91-18, School of Public Health and Tropical Medicine, Tulane University, New Orleans, LA.

CSA, 1997, Radionuclides, Metals and Hydrocarbons in Oil and Gas Operational Discharges And Environmental Samples Associated with Offshore Production Facilities on the Texas/Louisiana Continental Shelf with an Environmental Assessment of Metals and Hydrocarbons, prepared by Continental Shelf Associates, Inc., Jupiter Florida, for the United States Department of Energy.

Dellenbarger, L., A. Schupp and B. Kanjilal, 1993, Seafood Consumption in Coastal Louisiana, Louisiana Department of Environmental Quality, Baton Rouge, LA.

Ditton, R.B. and Auyong, J., 1984, Fishing Offshore Platforms Central Gulf of Mexico -- An Analysis of Recreational and Commercial Fishing Use at 164 Major Offshore Petroleum Structures;, OCS Monograph MMS 84-0006, Minerals Management Service, Gulf of Mexico OCS Regional Office, Metairie, LA.

Ebert, E.S, P.S. Price, R.E. Keenan, 1994, "Selection of Fish Consumption Estimates for Use in the Regulatory Process", Journal of Exposure Analysis and Environmental Epidemiology, 4:3:373-393.

Federal Register, 1991, National Primary Drinking Water Regulations; Radionuclides, United States Environmental Protection Agency, 40 CFR Parts 141,142, 56:138:33050.

Hart, A.D., B.D. Graham, D.A. Gettleson, D.C. Demorest and B.W. Smith, 1996, "Naturally Occurring Radioactive Materials Associated With Offshore Produced Water Discharges in the Gulf of Mexico", in: M. Reed and S. Johnsen, eds., Produced Water 2: Environmental Issues and Mitigation Technologies, Plenum Press, New York.

HEAST, 1995, Health Effects Assessment Summary Tables, FY-1995 Supplement, EPA/540/R-95/142, United States Environmental Protection Agency. 
IAEA, 1985, Sediment Kds and Concentration Factors for Radionuclides in the Environment, Technical Report Series No. 247, International Atomic Energy Agency, Vienna.

ICRP, 1994, "Age Dependent Doses to Members of the Public From Ingestion of Radionuclides", Recommendations of the International Commission on Radiological Protection", Publication 67, Annals of the ICRP, 23 Pergamon Press, Oxford.

ICRP, 1991, "1990 Recommendations of the International Commission on Radiological Protection", Publication 60, Annals of the ICRP, 21:1-3, Pergamon Press, Oxford.

Kelso, W.E., B.D. Rogers, D.A. Rutherford and D.R. Rogers, 1991, Survey of Louisiana Sport Fishermen - 1990, Louisiana State University Agricultural Center for the Louisiana Department of Wildlife and Fisheries, LAES Mimeo Report No. 57, April 1991.

Meinhold, A.F., S. Holtzman and L. D. Hamilton, 1995, "Human Health Risk Assessment for Radium Discharged Offshore in Produced Water", Proceedings of the SPE/EPA Exploration and Production Environmental Conference, Houston TX.

NCRP, 1997, Uncertainties in Fatal Cancer Risk Estimates Used in Radiation Protection, National Council on Radiation Protection and Measurements, Bethesda, MD., NCRP Report No. 126.

NCRP, 1993, Limitation of Exposure to lonizing Radiation, National Council on Radiation Protection and Measurements, Bethedsa, MD., NCRP Report No. 116.

NMFS, 1992, Fisheries of the United States, 1991, Current Fishery Statistics No. 9100, National Marine Fisheries Service, Silver Spring, MD.

NMFS, 1993, Data tapes provided to USEPA, as cited in USEPA, 1997.

NRC, 1983, Risk Assessment in the Federal Government: Managing the Process, National Research Council, National Academy Press, Washington, D.C.

Pao, E.M., K.H. Fleming. P.M. Guenther and S.J. Mickle, 1982, Foods Commonly Eaten by Individuals: Amount Per Day and Per Eating Occasion, United States Department of Agriculture, Home Economics Report No. 44. 
Pierce, D., Noviello, D., and Rigers, S., 1981, Commencement Bay Seafood Consumption Study, Tacoma-Pierce County Health Department Seattle, WA., December. as cited in USEPA, 1990.

Price, P.S., Su, S.H., and M.N. Gray, 1994, "The Effect of Sampling Bias on Estimates of Angler Consumption Rates in Creel Surveys", J. Exposure Analysis and Environmental Epiderniology, 4:3 355-372.

Puffer, H.W., Azen, S.P., Duda, M.J., and Young, D.R., 1981. Consumption Rates of Potentially Hazardous Marine Fish Caught in the Metropolitan Los Angeles Area. Grant No. R 807 120010. University of Southern California School of Medicine for Environmental Research Laboratory, U.S. Environmental Protection Agency, as cited in USEPA, 1990.

Reggio, V.C., Jr., 1987, Rigs To Reefs. The Use of Obsolete Petroleum Structures as Artificial Reefs, OCS Report MMS87-0015, United States Department of Interior, Minerals Management Service, Gulf of Mexico OCS Region, New Orleans, 17p.

Seiler, F., and Alvarez, J.L., 1996, "On the Selection of Distributions for Stochastic Variables", Risk Analysis 16: 5-18.

Stanley, D.R. and C.A. Wilson, 1990, "A Fishing-Dependent Based Study of Fish Species Composition and Associated Catch Rates Around Oil and Gas Structures off Louisiana", U.S. Fishery Bulletin 88:719-730.

Steimle \& Associates, Inc., 1995, Synthesis of Seafood Catch, Distribution, And Consumption Patterns in the Gulf of Mexico Region, report prepared for the United States Department of Energy, New Orleans, LA.

Schultz, F.E., S.E. Steimle, M.M. Mulino, J.C. Francis and D.H. Redmann, 1996, "Distribution of Finfish Caught Near Oilfield Structures Along Coastal Louisiana and Texas" pp. 381-394, in: M. Reed and S. Johnsen, eds., Produced Water 2: Environmental Issues and Mitigation Technologies, Plenum Press, New York.

Trefry, J.H., R.P. Trocine, K.L. Naito and S. Metz, 1996, "Assessing the Potential For Enhanced Bioaccumulation of Heavy Metals From Produced Water Discharges To the Gulf of Mexico" in: M. Reed and S. Johnsen, eds., Produced Water 2: Environmental /ssues and Mitigation Technologies, Plenum Press, New York.

USDA, 1983, Food Intakes: Individuals ir 48 States, Year 1977-1978, United States Department of Agriculture, Hyattsville, MD., Nationwide Food Consumption Survey 1977-78, Report No. 1-1. 
USEPA, 1989, Risk Assessment Guidance for Superfund, Volume I, Human Health Evaluation Manual (Part A) Interim Final, Office of Emergency and Remedial Response, EPA 540/1-89/002, United States Environmental Protection Agency, Washington, D.C.

USEPA, 1997, Exposure Factors Handbook, Office of Health and Environmental Assessment, United States Environmental Protection Agency, Washington, D.C., EPA $600 / P-95 / 002 F a$

USDOE, 1991, DOE Guidance on the Procedures in Applying the ALARA Process For Compliance with DOE 5400.5, Interim Guidance, Office of Environmental Guidance, Assistant Secretary, Environment, Safety and Health, United States Department of Energy, March 8, 1991.

Witzig, J., 1986, "Fishing in the Gulf of Mexico, 1984, Marine Recreational Fishing Results", in: Proc. Sixth Annual Gulf of Mexico Information Transfer Meeting, pp. 103 - 105, OCS Study MMS86-0073, United States Department of Interior, Minerals Management Service, Gulf of Mexico OCS Region, New Orleans. 


\section{APPENDIX A \\ SURVEY INSTRUMENT FOR RECREATIONAL FISHERMEN \\ (from Steimle \& Associates, 1995)}




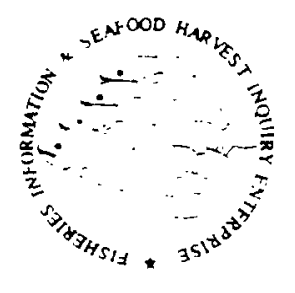

\section{F IS H I E}

P. O. BOX 1165 - METAIRIE, LA 70004

TELEPHONE (504) 831-2099 • FAX (504: 935.9410

\section{LOUISIANA/TEXAS \\ RECREATIONAL FISHERMEN INTERCEPT QUESTIONNAIRE}

Date of interview:

Time: a.m. p.m.

Location of interview:

$$
\text { (dock, city, state) }
$$

Case I.D. Number: Name of Interviewer:

Introduction:

Hello, I am (name of interviewer), with FISHIE. We are conducting a profile study for the United States Department of Energy to determine what seafood is caught, distributed, and consumed. The purpose of this study is to gather information on the effects of oil/gas structures on the inshore and offshore waters and fisheries of coastal Louisiana and Texas. We have a letter of endorsement from (assoc/organization) concerning this study. (Show fisherman letter of endorsement.) May we take a few minutes of your time today to ask you a few questions about your seafood catch from today's fishing trip. Your name will not be associated with your response. 


\section{QUESTIOṄS:}

1. FISHERMAN PROFILE.

a. What category(s) have you fished over the past 3 months?

fin fish shrimp crab c_oyster

b. What type of fishing license(s) do you hold?

in-state

out-of-state

both in-state and out-of-state

c. How many people in your household eat seafood?

d. Please provide the following demographic information about you and all the people in your household:

(1) Gender: __ Number of all Males __ Number of all Females

(2) Ages of Adults:

(3) Number of children (under the age of $\overline{18) \text { : }}$

(4) Race: Black _H: panic Oriental White Native American

(5) How many females within your household are between the ages of 14 and 50 ?

2. MODE OF FISHING.

a. How many fishing trips during the last three months have you made? trips

b. How many of the fishing trips you indicated above were spent in each of the following situations/locations?

off pier, dock, jetty, breakwater, seawalls, bridge, causeway, and/or shorelines/beach/bank private boat in inshore waters private boat in offshore waters charter/party boats

3. LOCATION OF SEAFOOD CATCH.

a. On the map we have here, please show us the zone or region(s) across the Gulf Coast (Louisiana \& Texas) where you fished in the past 3 months. (Indicate all that apply.) Zone/Regions: 1 2 $3-4-5-6-7-8-9$.

b. During the past 3 months approxima:ely what percentage of your catch was caught $\%$ inshore (inside the barrier islands)?

$\%$ less than 3 miles offshore (outside the barrier islands)?

$\% 3$ to 10 miles offshore?

$\%$ greater than 10 miles offshore?

$100 \%$ Total

c. Based on your answers to question 2.b., please estimate the number of trips that were made at the following distances frorn offshore/inshore oil/gas platforms? within 1,000 feet from 1,000 feet to $1 / 2$ mile from $1 / 2$ mile to a mile more than a mile 
4. SPECIES, QUANTITY, \& DISTRIBUTION OF SEAFOOD CAUGHT. What species and approximate quantity of finfish and shellfish were caught and kept from your catch during the past 3 months? Of your total catch for each species, what percentage will be for personal consumption and what percentage will be given to others for consumption? Indicate (circle) the unit of measurements for quantity caught.

(Key: $\#=$ number, $l b=$ pounds, doz=dozen, $s a=$ sack)

$\begin{array}{lll}\text { Shellfish Caught } & \begin{array}{l}\text { Quantity } \\ \text { Caught }\end{array} \\ \begin{array}{l}\text { Shrimp } \\ \text { Blue Crab } \\ \text { Oysters }\end{array} & \text { \% lb Kept for } \\ \end{array}$

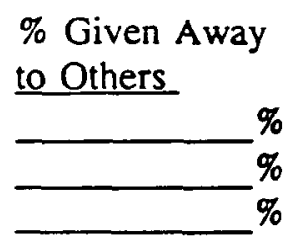

Finfish Caught

Amberjack

Black Drum

Croaker

Dolphin

Flounder

Grouper

Kingfish

King Mackerel

Redfish

Red Snapper

Shark

Sheepshead

Spanish Mackerel

Speckled Trout

Tuna

Vermilion Snapper
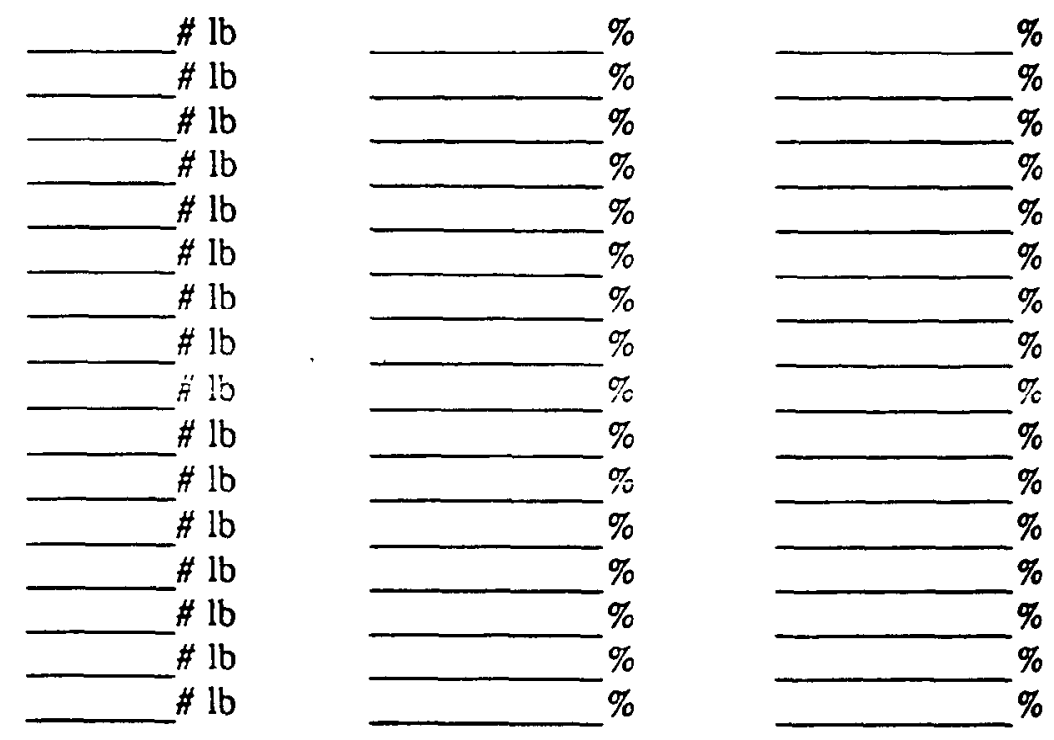

Other (Specify)
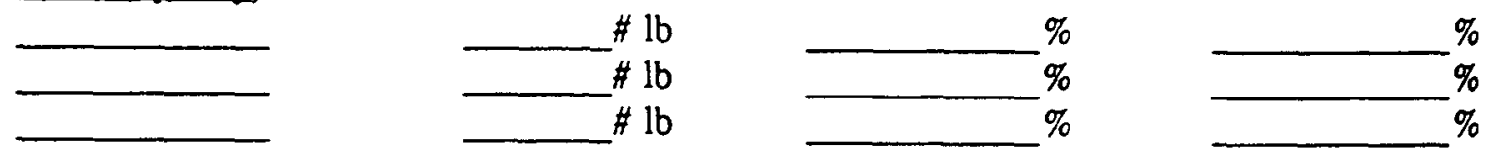

5. FREQUENCY OF FISH SERVED.

a. On the average, how many times per week has fish that you caught during the past 3 months been served/eaten in your household?

b. How many days has it been since the last meal served in your household was of fish you caught during the past 3 months? days This fish meal was not served. 
6. PERSONAL CONSUMPTION AND USE PATTERNS. Of the fish you kept for your personal use, which species were eaten by you and the members of your household? What parts of the fish (meat and/or skin) were eaten?

\section{Finfish Parts Consumed}

Finfish
Amberjack
Black Drum
Croaker
Dolphin
Flounder
Grouper
Kingfish
King Mackerel
Redfish
Red Snapper
Shark
Sheepshead
Spanish Mackerel
Speckled Trout
Tuna
Vermilion Snapper
Other

7. COOKING METHODS. What method(s) of cooking were used to prepare the seafood you caugnt during the past 3 montins? Check ail that apply?

baked, barbecued, _blackened, _boiled/poached, _broiled, __fried,

_ grilled, __smoked, _stew/soup, _other (please specify ___

8. What is the ZIP CODE where you currently live?

9. Have you been interviewed by us before? ___ Yes ___ No

10. Do you belong to a fishing sports club? ___ Yes ___ No If yes, please provide name of club: location of club:

\section{Follow Up Information:}

Would you provide us your name and telephone number for the purpose of a follow-up interview? Yes No

If Yes, what is your name?

What is your telephone: area code )

What is your current address?

$$
\text { Zip Code }
$$

Thank you for your valuable time in providing this information! 


\section{APPENDIX B \\ ${ }^{210} \mathrm{~Pb},{ }^{226} \mathrm{Ra}$ and ${ }^{228} \mathrm{Ra}$ in BIOTA CAUGHT NEAR OFFSHORE PLATFORMS}

Data And Statistical Analyses 
Table B-1. Fish species and platform codes used in SAS runs.

\begin{tabular}{|lc|lc|}
\hline \multicolumn{1}{|l|}{ Finfish Species } & Code & \multicolumn{1}{|c|}{ Platform } & Code \\
\hline Atlantic Croaker & 1 & $\begin{array}{l}\text { Sonnier Bank } \\
\text { (REFERENCE) }\end{array}$ & 1 \\
\hline Black Drum & 2 & $\begin{array}{l}\text { SMI229 } \\
\text { (REFERENCE) }\end{array}$ & 2 \\
\hline Flounders & 3 & El313 & 3 \\
\hline Gray Triggerfish & 4 & HI323 & 4 \\
\hline Greater Amberjack & 5 & HI382 & 5 \\
\hline Grunts & 6 & HI595 & 6 \\
\hline Lane Snapper & 7 & MI703 & 7 \\
\hline Longspine Porgy & 8 & SMl130 & 8 \\
\hline Longtail Bass & 9 & SMI236 & 9 \\
\hline Red Snapper & 10 & V214 & 10 \\
\hline Redfish & 11 & & \\
\hline Sea Bass & 12 & & \\
\hline Speckled Trout & 13 & & \\
\hline Trouts & 14 & & \\
\hline Vermillion Snapper & 15 & & \\
\hline Wenchman & 16 & & \\
\hline
\end{tabular}


Table B-2. Data set used in quantitative risk assessment.

\begin{tabular}{|c|c|c|c|c|c|c|c|}
\hline PLATFORM & \begin{tabular}{|l|} 
PLATFORM \\
CODE
\end{tabular} & SPECIES & $\begin{array}{l}\text { SPECIES } \\
\text { CODE }\end{array}$ & TISSUE & $\begin{array}{l}{[\mathrm{Pb} 210]} \\
\mathrm{pCi} / \mathrm{g}\end{array}$ & \begin{tabular}{|l}
{$[\mathrm{Ra226}]$} \\
$\mathrm{pCi} / \mathrm{g}$
\end{tabular} & $\begin{array}{l}\text { [Ra228] } \\
\mathrm{pCi} / \mathrm{g}\end{array}$ \\
\hline \multicolumn{8}{|c|}{ Reference Stations } \\
\hline Sonnier Bank & 1 & Gray Triggerfish & & Fillet & 0.01 & 0.002 & \\
\hline Sonnier Bank & 1 & Gray Triggerfish & & Fillet & 0.028 & 0.008 & 0 \\
\hline Sonnier Bank & 1 & Gray Triggerfish & & Fillet & 0.023 & 0.007 & 0 \\
\hline Sonnier Bank & 1 & Gray Triggerfish & & Fillet & 0.041 & 0.005 & 0 \\
\hline Sonnier Bank & 1 & Gray Triggerfish & & Fillet & 0.024 & 0 & 0.154 \\
\hline Sonnier Bank & 1 & Grunt & & Fillet & 0.0035 & 0.007 & 0 \\
\hline Sonnier Bank & 1 & Grunt & & Fillet & 0.019 & 0.002 & 0 \\
\hline Sonnier Bank & 1 & Grunt & & Fillet & 0.009 & 0.004 & 0 \\
\hline Sonnier Bank & 1 & Grunt & & Fillet & 0 & 0.005 & 0 \\
\hline Sonnier Bank & 1 & Grunt & & Fillet & 0 & 0.012 & 0 \\
\hline Sonnier Bank & 1 & Longspine Porgy & & Whole & 0.029 & 0.04 & 0.009 \\
\hline Sonnier Bank & 1 & Longspine Porgy & & Whole & 0.124 & 0.046 & 0.072 \\
\hline Sonnier Bank & 1 & Longspine Porgy & & Whole & 0.126 & 0.045 & 0.012 \\
\hline Sonnier Bank & 1 & Longspine Porgy & & Whole & 0.055 & 0.033 & 0.017 \\
\hline Sonnier Bank & 1 & Longspine Porgy & & Whole & 0.069 & 0.023 & 0.08 \\
\hline Sonnier Bank & 1 & Red Snapper & 10 & Fillet & 0.025 & 0 & 0 \\
\hline Sonnier Bank & 1 & Red Snapper & 10 & Fillet & 0.013 & 0.002 & 0 \\
\hline Sonnier Bank & 1 & Red Snapper & 10 & Fillet & 0.019 & 0.002 & 0 \\
\hline Sonnier Bank & 1 & Red Snapper & 10 & Fillet & 0 & 0.002 & 0 \\
\hline Sonnier Bank & 1 & Red Snapper & 10 & Fillet & 0.003 & 0.005 & 0.028 \\
\hline Sonnier Bank & 1 & Seabass & 12 & Fillet & 0 & 0 & 0 \\
\hline Sonnier Bank & 1 & Wenchman & 16 & Whole & 0.042 & 0.02 & 0.029 \\
\hline Sonnier Bank & 1 & Wenchman & 16 & Whole & 0.031 & 0.017 & 0.022 \\
\hline Sonnier Bank & 1 & Wenchman & 16 & Whole & 0.005 & 0.005 & 0.017 \\
\hline SMI229 & 2 & Atlantic Croaker & & Whole & 0.018 & 0.026 & 0.034 \\
\hline SMI229 & 2 & Atlantic Croaker & 1 & Whole & 0.01 & 0.013 & 0.016 \\
\hline SMI229 & 2 & Atlantic Croaker & 1 & Whole & 0.011 & 0.008 & 0 \\
\hline SMI229 & 2 & Atlantic Croaker & & Whole & 0.0045 & 0.003 & 0 \\
\hline SMI229 & 2 & Atlantic Croaker & & Whole & 0.01 & 0.009 & 0.036 \\
\hline SMI229 & 2 & Speckled Trout & $\overline{13}$ & Edible & 0 & 0.002 & 0.004 \\
\hline SMI229 & 2 & Speckled Trout & 13 & Edible & 0 & 0.001 & 0 \\
\hline SMI229 & 2 & Speckled Trout & 13 & $3 \longdiv { \text { Edible } }$ & 0 & 0.001 & 0.007 \\
\hline SMI229 & 2 & Trout & 14 & 4Whole & O & 0.007 & 0.009 \\
\hline SMI229 & 2 & Trout & 14 & 4Whole & 0 & 0.005 & 0 \\
\hline SMI229 & 2 & Trout & $\overline{14}$ & Whole & 0 & 0.011 & 0.0065 \\
\hline SMI229 & 2 & Trout & 14 & 4Whole & 0.0035 & 0.011 & 0.023 \\
\hline SMI229 & 2 & Trout & 14 & 4 Whole & 0 & 0.005 & 0 \\
\hline \multicolumn{8}{|c|}{ Discharging Stations } \\
\hline$E 1313$ & 3 & Gray Triggerfish & 4 & 4 Fillet & 0 & 0.002 & 0.051 \\
\hline$E / 313$ & 3 & Gray Triggerfish & 4 & 4 Fillet & 0.016 & 0.004 & 0.03 \\
\hline $\mathrm{E} 1313$ & 3 & Gray Triggerfish & 4 & $4 \mid$ Fillet & 0 & 0.009 & 0.043 \\
\hline$E 1313$ & 3 & Gray Triggerfish & 4 & \begin{tabular}{l|l|}
4 Fillet \\
\end{tabular} & 0.005 & 0.0025 & 0 \\
\hline$E \mid 313$ & 3 & Gray Triggerfish & 4 & 4 Fillet & 0 & 0.009 & 0 \\
\hline El313 & 3 & Longspine Porgy & 8 & 8) Whole & 0.131 & 0.012 & 0.006 \\
\hline EI313 & 3 & Longspine Porgy & 8 & 8 Whole & 0.134 & 0.033 & 0.058 \\
\hline EI313 & 3 & Longspine Porgy & 8 & 8. Whole & 0.016 & 0.021 & 0.044 \\
\hline$E 1313$ & 3 & Longspine Porgy & 8 & Whole & 0.111 & 0.024 & 0.036 \\
\hline$E 1313$ & 3 & Longspine Porgy & & 8 Whole & 0.134 & 0.037 & 0.007 \\
\hline
\end{tabular}


Table B-3. (cont.)

\begin{tabular}{|c|c|c|c|c|c|c|c|}
\hline PLATFORM & $\begin{array}{l}\text { PLATFORM } \\
\text { CODE }\end{array}$ & SPECIES & \begin{tabular}{|l|} 
SPECIES \\
CODE
\end{tabular} & TISSUE & $=\begin{array}{l}{[\mathrm{Pb} 210]} \\
\mathrm{pCi} / \mathrm{g}\end{array}$ & \begin{tabular}{|l|} 
Ra226] \\
$\mathrm{pCi} / \mathrm{g}$
\end{tabular} & $\begin{array}{l}{[\mathrm{Ra228]}} \\
\mathrm{pCi} / \mathrm{g}\end{array}$ \\
\hline$E \mid 313$ & 3 & Red Snapper & \begin{tabular}{|r}
10 \\
\end{tabular} & Fillet & 0.028 & 0.0015 & 0.0065 \\
\hline$E / 313$ & 3 & Red Snapper & 10 & Fillet & 0.018 & 0 & 0.022 \\
\hline$E 1313$ & 3 & Red Snapper & 10 & Fillet & 0.011 & 0.0015 & 0.013 \\
\hline$E \mid 313$ & 3 & Red Snapper & 10 & Fillet & 0.023 & 0.003 & 0.016 \\
\hline$E \mid 313$ & 3 & Red Snapper & 10 & Fillet & 0.019 & 0.0015 & 0.032 \\
\hline EI313 & 3 & Seabass & 12 & Fillet & 0 & 0 & 0.054 \\
\hline$E 1313$ & 3 & Seabass & 12 & Fillet & 0 & 0 & 0.032 \\
\hline$E / 313$ & 3 & Seabass & 12 & Fillet & 0.012 & 0.007 & 0.029 \\
\hline$E \mid 313$ & 3 & Seabass & 12 & Fillet & 0 & 0.002 & 0.024 \\
\hline$E / 313$ & 3 & Seabass & 12 & Whole & 0 & 0.002 & \\
\hline EI313 & 3 & Seabass & 12 & Whole & 0.0045 & 0.002 & 0 \\
\hline$E 1313$ & 3 & Seabass & 12 & Whole & 0.027 & 0.002 & 0.012 \\
\hline$E \mid 313$ & 3 & Seabass & 12 & Whole & 0 & 0.002 & 0.014 \\
\hline$E[313$ & 3 & Seabass & 12 & Whole & 0 & 0.002 & 0.02 \\
\hline $\mathrm{HI} 323$ & 4 & Gray Triggerfish & & Fillet & 0.032 & 0.006 & 0.007 \\
\hline HI323 & 4 & Gray Triggerfish & & Fillet & 0 & 0.006 & 0.018 \\
\hline $\mathrm{HI} 323$ & 4 & Greater Amberjack & & Fillet & 0.03 & 0.001 & 0.04 \\
\hline $\mathrm{HI} 323$ & 4 & Greater Amberjack & & Fillet & 0.036 & 0.004 & 0.0055 \\
\hline $\mathrm{HI} 323$ & 4 & Grunt & & Fillet & 0.005 & 0.002 & \\
\hline HI323 & 4 & Grunt & & Fillet & 0.02 & 0.003 & 0.0075 \\
\hline $\mathrm{HI} 323$ & 4 & Grunt & & Fillet & 0 & 0.002 & 0.044 \\
\hline $\mathrm{HI323}$ & 4 & Grunt & & Fillet & 0.012 & 0.002 & 0.007 \\
\hline $\mathrm{HI323}$ & 4 & Grunt & & Fillet & 0.012 & 0.001 & 0.032 \\
\hline $\mathrm{HI} 323$ & 4 & Longspine Porgy & & Whole & 0.261 & 0.0025 & 0.085 \\
\hline $\mathrm{HI} 323$ & 4 & Longspine Porgy & & Whole & 0.303 & 0.01 & 0.076 \\
\hline $\mathrm{HI} 323$ & 4 & Longspine Porgy & & Whole & 0.195 & 0.04 & 0.085 \\
\hline $\mathrm{HI} 323$ & 4 & \begin{tabular}{|l} 
Longspine Porgy \\
\end{tabular} & 8 & Whole & 0.241 & 0.006 & 0.061 \\
\hline $\mathrm{HI} 323$ & 4 & \begin{tabular}{|l} 
Longspine Porgy \\
\end{tabular} & 8 & Whole & 0.299 & 0.015 & 0.05 \\
\hline HI323 & 4 & $\begin{array}{l}\text { Red Snapper } \\
\end{array}$ & 10 & Fillet & 0 & 0.0025 & 0.0085 \\
\hline $\mathrm{HI323}$ & 4 & Red Snapper & 10 & Fillet & 0 & 0 & 0 \\
\hline $\mathrm{HI} 323$ & 4 & Red Snapper & 10 & Fillet & 0.0045 & $\underline{0}$ & \\
\hline $\mathrm{HI} 323$ & 4 & Red Snapper & 10 & Fillet & 0 & 0 & 0.146 \\
\hline $\mathrm{HI323}$ & 4 & Red Snapper & 10 & Fillet & 0 & $\underline{0}$ & 0.098 \\
\hline $\mathrm{HI} 323$ & 4 & Seabass & 12 & Fillet & 0.005 & 0 & \\
\hline $\mathrm{HI} 323$ & 4 & Seabass & 12 & Whole & 0 & 0.011 & $\underline{0}$ \\
\hline $\mathrm{HI} 323$ & 4 & Seabass & 12 & Whole & 0.0045 & 0.013 & \\
\hline $\mathrm{H} 1323$ & 4 & Seabass & 12 & Whole & 0.027 & 0.009 & 0.012 \\
\hline $\mathrm{HI} 323$ & 4 & Seabass & 12 & Whole & 0 & 0.008 & 0.014 \\
\hline $\mathrm{HI} 323$ & 4 & Seabass & 12 & Whole & 0 & 0.004 & 0.02 \\
\hline $\mathrm{HI} 323$ & 4 & Vermilion Snapper & 15 & Fillet & 0 & 0.0025 & \\
\hline $\mathrm{HI} 323$ & 4 & Vermilion Snapper & 15 & Fillet & 0 & 0 & \\
\hline $\mathrm{HI323}$ & 4 & Vermilion Snapper & 15 & Fillet & 0 & 0 & 0 \\
\hline $\mathrm{HI} 323$ & 4 & Vermilion Snapper & 15 & Fillet & 0 & 0.005 & \\
\hline $\mathrm{H} 1323$ & 4 & Vermilion Snapper & 15 & Fillet & 0 & 0.012 & \\
\hline $\mathrm{HI} 382$ & 5 & Gray Triggerfish & & Fillet & 0.009 & 0 & 0.049 \\
\hline $\mathrm{H} 1382$ & 5 & Greater Amberjack & 5 & Fillet & 0.021 & 0 & 0.008 \\
\hline $\mathrm{H} 1382$ & 5 & Longspine Porgy & 8 & Whole & 0.212 & 0.024 & 0.101 \\
\hline $\mathrm{HI} 382$ & 5 & \begin{tabular}{|l} 
Longspine Porgy \\
\end{tabular} & & Whole & 0.236 & 0.028 & 0.163 \\
\hline $\mathrm{H} \mid 382$ & 5 & Longspine Porgy & & Whole & 0.129 & 0 & 0.037 \\
\hline $\mathrm{HI} 382$ & 5 & Longspine Porgy & & Whole & 0.179 & 0 & \\
\hline
\end{tabular}


Table B-3. (cont.)

\begin{tabular}{|c|c|c|c|c|c|c|c|}
\hline PLATFORM & \begin{tabular}{|l|} 
PLATFORM \\
CODE \\
\end{tabular} & SPECIES & \begin{tabular}{|l|}
$\begin{array}{l}\text { SPECIES } \\
\text { CODE }\end{array}$ \\
\end{tabular} & TISSUE & \begin{tabular}{|l|} 
Pb210] \\
pCi $/ \mathrm{g}$
\end{tabular} & $\begin{array}{l}{[\text { Ra226] }} \\
\text { pCi/g }\end{array}$ & $\begin{array}{l}{[\text { Ra228] }} \\
\text { pCi/g }\end{array}$ \\
\hline$H \mid 382$ & \begin{tabular}{|l|}
5 \\
\end{tabular} & Longspine Porgy & & Whole & 0.261 & & 0.022 \\
\hline$H 1382$ & 5 & Wenchman & 16 & Whole & 0.012 & 0.006 & 0.017 \\
\hline$H 1382$ & 5 & Wenchman & 16 & Whole & 0.005 & 0.008 & 0.017 \\
\hline HI382 & 5 & Wenchman & & Whole & 0.005 & 0.007 & 0.0065 \\
\hline HI382 & 5 & Wenchman & 16 & Whole & 0.0055 & 0.008 & 0.039 \\
\hline$H 1382$ & 5 & Wenchman & & Whole & 0.018 & 0.009 & 0.046 \\
\hline H1595 & 6 & Gray Triggerfish & & Fillet & 0 & 0.002 & \\
\hline HI595 & 6 & Gray Triggerfish & & Fillet & 0.014 & 0.011 & \\
\hline HI595 & 6 & Longspine Porgy & & Whole & 0.162 & 0.042 & 0.089 \\
\hline HI595 & 6 & Longspine Porgy & & Whole & 0.153 & 0.037 & 0.058 \\
\hline HI595 & 6 & Longspine Porgy & & Whole & 0.143 & 0.037 & 0.041 \\
\hline HI595 & 6 & Longspine Porgy & & Whole & 0.122 & 0.027 & 0.025 \\
\hline HI595 & 6 & Longspine Porgy & & Whole & 0.124 & 0.035 & 0.052 \\
\hline HI595 & 6 & Longtailed Bass & & Fillet & 0.011 & 0.005 & 0.507 \\
\hline HI595 & 6 & Longtailed Bass & & Fillet & 0.017 & 0.005 & \\
\hline HI595 & 6 & Longtailed Bass & & Fillet & 0 & 0.0025 & 0.045 \\
\hline HI595 & 6 & Longtailed Bass & & Fillet & 0 & 0.005 & \\
\hline H1595 & 6 & Longtailed Bass & & Fillet & 0 & 0.009 & \\
\hline $\mathrm{HI595}$ & 6 & Seabass & 12 & Fillet & 0.018 & 0 & of \\
\hline H1595 & 6 & Seabass & 12 & Fillet & 0.0045 & 0 & if \\
\hline HI595 & 6 & Seabass & 12 & Whole & 0.066 & 0.02 & \\
\hline HI595 & 6 & Seabass & & Whole & 0.008 & 0 & if \\
\hline H1595 & 6 & Vermilion Snapper & 15 & Fillet & 0 & 0.005 & 0.12 \\
\hline HI595 & 6 & Vermilion Snapper & 15 & Fillet & 0 & 0.0025 & 0.171 \\
\hline HI595 & 6 & Vermilion Snapper & & Fillet & 0 & 0.016 & \\
\hline HI595 & 6 & Wenchman & & Whole & 0.027 & 0 & 0.022 \\
\hline HI595 & 6 & Wenchman & & Whole & 0.031 & 0 & 0.051 \\
\hline HI595 & 6 & Wenc & & Whole & 0.02 & 0 & 0.044 \\
\hline HI595 & 6 & Wenchman & & Whole & 0.045 & 0 & 0.031 \\
\hline HI595 & 6 & Wenchman & & Whole & 0.031 & 0 & 0.025 \\
\hline M1703 & 7 & Flounder & & Fillet & 0.004 & 0.005 & 0.007 \\
\hline M1703 & 7 & Gray Triggerfish & & Fillet & 0.009 & 0.005 & 0.087 \\
\hline M1703 & 7 & Gray Triggerfish & & Fillet & 0.023 & 0 & 0.045 \\
\hline M1703 & 7 & Gray Triggerfish & & Fillet & 0.025 & 0.004 & 0.078 \\
\hline MI703 & 7 & Gray Triggerfish & & Fillet & 0.003 & 0.002 & 0.137 \\
\hline M1703 & 7 & Gray Triggerfish & & Fillet & 0 & 0.007 & 0.109 \\
\hline MI703 & 7 & Red Snapper & 10 & Fillet & $\overline{0}$ & 0.0015 & \\
\hline M1703 & 7 & Red Snapper & & Fillet & 0 & 0 & t \\
\hline M1703 & 7 & Red Snapper & & Fillet & 0 & 0 & \\
\hline M1703 & 7 & Red Snapper & 10 & Fillet & 0 & 0 & f \\
\hline M1703 & 7 & Red Snapper & 10 & Fillet & 0 & 0 & of \\
\hline M1703 & 7 & Seaba: & & Whole & 0.022 & 0.016 & \\
\hline M1703 & 7 & Seabass & 12 & Whole & 0.03 & 0.008 & 3 \\
\hline M1703 & 7 & Seabass & 12 & Whole & 0 & 0.0025 & \\
\hline M1703 & 7 & Seabass & 12 & Whole & 0.005 & 0 & 0 \\
\hline M1703 & 7 & Seabass & 12 & Whole & 0.0045 & 0 & \\
\hline SMI130 & 8 & Gray Triggerfish & & Fillet & 0.021 & 0 & \\
\hline SMI130 & 8 & Gray Triggerfish & & Fillet & 0.009 & 0.002 & \\
\hline SMI130 & 8 & Gray Triggerfish & & Fillet & 0.043 & 0 & \\
\hline
\end{tabular}


Table B-3. (cont.)

\begin{tabular}{|c|c|c|c|c|c|c|c|}
\hline PLATFORM & $\begin{array}{l}\text { PLATFORM } \\
\text { CODE }\end{array}$ & SPECIES & $\begin{array}{l}\text { SPECIES } \\
\text { CODE }\end{array}$ & TISSUE & $=\left[\begin{array}{l}{[\mathrm{Pb} 210]} \\
\mathrm{pCi} / \mathrm{g}\end{array}\right.$ & $\begin{array}{l}{[\mathrm{Ra226}]} \\
\mathrm{pCi} / \mathrm{g}\end{array}$ & $\begin{array}{l}{[\mathrm{Ra228}]} \\
\mathrm{pCi} / \mathrm{g}\end{array}$ \\
\hline SMI130 & 8 & Gray Triggerfish & & Fillet & 0.05 & 0.002 & 0.025 \\
\hline SMI130 & 8 & Gray Triggerfish & & Fillet & 0.036 & 0.011 & \\
\hline SMI130 & 8 & Greater Amberjack & & Fillet & 0.022 & 0.005 & 0.037 \\
\hline SMI130 & 8 & Greater Amberjack & & Fillet & 0.01 & 0.005 & 0.124 \\
\hline SMI130 & 8 & Longspine Porgy & & Whole & 0.126 & 0.017 & 0 \\
\hline SMI130 & 8 & Longspine Porgy & & Whole & 0.096 & 0.018 & 0.075 \\
\hline SMI130 & 8 & Longspine Porgy & & Whole & 0.122 & 0.016 & 0.056 \\
\hline SMI130 & 8 & Longspine Porgy & & Whole & 0.149 & 0.021 & 0.14 \\
\hline SMI130 & 8 & Longspine Porgy & & Whole & 0.16 & 0.02 & 0.108 \\
\hline SMI130 & 8 & Red Snapper & 10 & Fillet & 0 & 0.0025 & \\
\hline SMI130 & 8 & Red Snapper & & Fillet & 0 & 0.002 & \\
\hline SMI130 & 8 & Red Snapper & 10 & Fillet & 0 & 0.0025 & 0.058 \\
\hline SMI130 & 8 & Red Snapper & 10 & Fillet & 0.005 & 0.0025 & 0.14 \\
\hline SMl130 & 8 & Red Snapper & 10 & Fillet & 0 & 0.008 & 0.019 \\
\hline SMI130 & 8 & Seabass & 12 & Fillet & 0 & 0 & \\
\hline SMI130 & 8 & Seabass & 12 & Fillet & 0 & 0 & 0.022 \\
\hline SMI130 & 8 & Seabass & 12 & Whole & 0 & 0 & 0.076 \\
\hline SMI130 & 8 & Seabass & 12 & Whole & 0 & 0.01 & 0.076 \\
\hline SMI130 & 8 & Seabass & 12 & Whole & 0 & 0.003 & 0.031 \\
\hline SMI130 & 8 & Seabass & 12 & Whole & 0.0045 & 0 & \\
\hline SMI130 & 8 & Seabass & 12 & Whole & 0.011 & 0.0025 & 0.018 \\
\hline SMI130 & 8 & Vermilion Snapper & 15 & Fillet & 0.016 & 0.005 & 0.035 \\
\hline SMI130 & 8 & Vermilion Snapper & 15 & Fillet & 0.034 & 0.005 & 0.067 \\
\hline SMI236 & 9 & Atlantic Croaker & & Whole & 0 & 0.004 & 0.013 \\
\hline SMI236 & 9 & Atlantic Croaker & & Whole & 0.015 & 0.003 & 0.0055 \\
\hline SM1236 & 9 & Atlantic Croaker & & Whole & 0.0045 & 0.0015 & 0.032 \\
\hline SMI236 & $\overline{9}$ & Atlantic Croaker & & Whole & 0.014 & 0.011 & 0.032 \\
\hline SMI236 & 9 & Atlantic Croaker & & Whole & 0.0045 & 0.0015 & 0.039 \\
\hline SMI236 & 9 & Black Drum & & Fillet & 0.0045 & 0 & 0 \\
\hline SMI236 & 9 & Black Drum & & Fillet & 0.015 & 0.002 & \\
\hline SMI236 & 9 & Redfish & 11 & Edible & 0.03 & 0.0025 & 0 \\
\hline SMI236 & 9 & Speckled Trout & 13 & Edible & 0.012 & 0.0025 & \\
\hline SMI236 & 9 & Trout & 14 & Whole & 0 & 0.004 & $\underline{0}$ \\
\hline SMI236 & 9 & Trout & 14 & Whole & 0.013 & 0.0025 & 0 \\
\hline SMI236 & 9 & Trout & 14 & Whole & 0.004 & 0.0025 & \\
\hline SMI236 & 9 & Trout & 14 & Whole & 0.016 & 0 & \\
\hline SMI236 & 9 & \begin{tabular}{|l|} 
Trout \\
\end{tabular} & 14 & Whole & 0 & 0.0025 & 0.0075 \\
\hline V214 & 10 & Gray Triggerfish & 4 & Fillet & 0.008 & 0.0025 & 0.009 \\
\hline V214 & 10 & Gray Triggerfish & 4 & Fillet & 0.013 & 0.0025 & 0.028 \\
\hline V214 & 10 & Gray Triggerfish & & Fillet & 0.013 & 0.0025 & 0.052 \\
\hline V214 & 10 & Gray Triggerfish & & Fillet & 0.023 & 0.0025 & 0.024 \\
\hline V214 & 10 & Gray Triggerfish & & Fillet & 0.005 & 0.006 & 0.041 \\
\hline V214 & 10 & Grunt & & Fillet & 0.011 & 0 & 0.119 \\
\hline V214 & 10 & Grunt & & Fillet & 0.022 & 0.01 & \\
\hline V214 & 10 & Grunt & & Fillet & 0.024 & 0.012 & \\
\hline V214 & 10 & Grunt & & Fillet & 0.035 & 0.011 & $\underline{0}$ \\
\hline V214 & 10 & Grunt & & Fillet & 0.017 & 0.012 & \\
\hline V214 & 10 & Lane Snapper & & Fillet & 0.013 & 0.015 & 0.042 \\
\hline V214 & 10 & Lane Snapper & & Fillet & 0.036 & 0 & 0.008 \\
\hline
\end{tabular}


Table B-3. (cont.)

\begin{tabular}{|c|c|c|c|c|c|c|c|}
\hline PLATFORM & $\begin{array}{l}\text { PLATFORM } \\
\text { CODE }\end{array}$ & SPECIES & $\begin{array}{l}\text { SPECIES } \\
\text { CODE }\end{array}$ & TISSUE & $\begin{array}{l}{[\mathrm{Pb} 210]} \\
\mathrm{pCi} / \mathrm{g}\end{array}$ & $\begin{array}{l}{[\mathrm{Ra226}]} \\
\mathrm{pCi} / \mathrm{g}\end{array}$ & $\begin{array}{l}\text { [Ra228] } \\
\text { pCi/g }\end{array}$ \\
\hline V214 & 10 & Lane Snapper & & Fillet & 0.023 & 0.0025 & \\
\hline V214 & 10 & Lane Snapper & & Fillet & 0 & 0.008 & \\
\hline V214 & 10 & Lane Snapper & & Fillet & 0.034 & 0.002 & 0.0075 \\
\hline V214 & 10 & Red Snapper & 10 & Fillet & 0.013 & 0 & \\
\hline V214 & 10 & Red Snapper & 10 & Fillet & 0.011 & 0.002 & \\
\hline V214 & 10 & Red Snapper & 10 & Fillet & 0 & 0.0025 & 0.008 \\
\hline V214 & 10 & Red Snapper & 10 & Fillet & 0.026 & 0.008 & \\
\hline V214 & 10 & Red Snapper & 10 & Fillet & 0 & 0 & \\
\hline V214 & 10 & Seabass & 12 & Whole & 0.04 & 0.008 & 0.03 \\
\hline & & & & & & & \\
\hline
\end{tabular}

